\title{
Investigação geotécnica e estudo de um processo erosivo causado por ocupação urbana
}

\begin{abstract}
Dissertação de Mestrado apresentada à Escola de Engenharia de São Carlos da Universidade de São Paulo, como parte dos requisitos para obtenção do título de Mestre em Ciências do Programa de Pósgraduação em Geotecnia.
\end{abstract}

Orientador: Prof. Dr. Heraldo Luiz Giacheti

São Carlos

2009 

FOLHA DE APROVAÇÃO

\title{
INVESTIGAÇÃO GEOTÉCNICA E ESTUDO DE UM PROCESSO EROSIVO CAUSADO POR OCUPAÇÃO URBANA
}

Daniela Massami Ide

\begin{abstract}
Dissertação de Mestrado apresentada à Escola de Engenharia de São Carlos da Universidade de São Paulo, como parte dos requisitos para obtenção do título de Mestre em Ciências do Programa de Pósgraduação em Geotecnia.
\end{abstract}

Aprovada em 14 de agosto de 2009.

BANCA EXAMINADORA

Prof. Dr. Sérgio Antônio Röhm UFSCAR

Prof. Dr. José Eduardo Rodrigues EESC/USP

Prof. Dr. Heraldo Luiz Giacheti

UNESP/Bauru - orientador 


\section{AGRADECIMENTOS}

Agradeço a todos que contribuíram para que fosse possível concluir esse trabalho, principalmente minha família.

Aos amigos de longa data e aos que conheci durante o mestrado. Às taruíras, pelas madrugadas que passamos em claro fazendo trabalho.

Ao Prof. Dr. Heraldo Luiz Giacheti, que desde a graduação me orienta pacientemente.

Aos professores, técnicos, funcionários e pós-graduandos do departamento de Geotecnia, pelo conhecimento passado e toda ajuda prestada.

Aos professores, técnicos, funcionários e alunos da UNESP/Bauru que auxiliaram nos ensaios de campo e laboratório.

À Escola de Engenharia de São Carlos (EESC/USP), por possibilitar a pós-graduação no curso de mestrado.

À Universidade Estadual Paulista Júlio de Mesquita Filho (UNESP) de Bauru, por possibilitar a utilização de sua estrutura e equipamentos.

Ao Instituto de Pesquisas Meteorológicas de Bauru (IPMET), pelo fornecimento dos dados pluviométricos.

Ao Conselho Nacional de Desenvolvimento Científico e Tecnológico (CNPq)/Capes, pela bolsa de estudos concedida, e à Fundação de Ampara à Pesquisa de São Paulo (FAPESP), pelo apoio financeiro dos ensaios de campo. 
"Um homem não é grande pelo que faz, mas pelo que renuncia." Albert Schweitzer 


\section{RESUMO}

\section{IDE, D. M. Investigação geotécnica e estudo de um processo erosivo causado por ocupação}

urbana. 2009. 129p. Dissertação (Mestrado) - Departamento de Geotecnia, Universidade de São Paulo, São Carlos-SP, 2009.

Esta dissertação apresenta os resultados da investigação geotécnica de uma área que apresenta processos erosivos, na cidade de Bauru, interior de São Paulo, com o objetivo de caracterizar o solo local e definir quais os principais fatores responsáveis pela evolução desses processos. Eles tiveram início com o desmatamento, impermeabilização do solo, deságüe de águas pluviais e esgoto e atingiram grandes dimensões com a implantação de loteamentos, com projeto inadequado e falta de obras de infra-estrutura de drenagem. Com observações de campo, ensaios in situ e laboratório, o fenômeno foi estudado com o intuito de se estabelecer um mecanismo que explique o processo erosivo. No local ocorrem desde solos residuais jovens de Arenito, a residuais maduros, muito evoluídos por processos pedogenéticos e em alguns pontos se tem também solos transportados. Foram realizados ensaios de caracterização, de erodibilidade e mecânicos em três amostras distintas e representativas de solos do local, além de ensaios de campo SPT. Esses solos foram classificados como uma areia pouco argilosa de coloração variável e quase sempre se encontram em condição não saturada. Os resultados dos ensaios de erodibilidade mostraram que os três métodos empregados classificaram os solos como altamente erodível, sendo o método mais interessante aquele proposto por Nogami \& Villibor (1979) para os solos estudados. A sucção exerce papel importante na resistência desses solos e a saturação das amostras promoveu a redução significativa da coesão. A água é o agente deflagrador e principal responsável pela evolução do processo erosivo, tanto pelo escoamento superficial como pelo escoamento subsuperficial. O seu fluxo no interior do maciço carreia material e modifica a distribuição granulométrica do solo, alterando também suas propriedades. 0 mecanismo de evolução se inicia com o aumento do teor de umidade do solo pela ação da chuva podendo, em alguns pontos, chegar-se a saturação, provocando a diminuição da resistência através da anulação do efeito da coesão. Uma vez saturado e com o fluxo de d'água, o solo pode perder sua estrutura por erosão interna retrogressiva, assim é facilmente destacado e carreado, provocando a instabilidade dos taludes e evolução do processo erosivo.

Palavras chave: processos erosivos, caracterização, mecanismo de evolução. 


\begin{abstract}
IDE, D. M. Geotechnical site characterization and study of an erosion process caused by

urban setting. 2009. 129 p. Dissertation (Master) - Departamento de Geotecnia, Universidade de São Paulo, São Carlos-SP, 2009.

This dissertation presents geotechnical site characterization results of an erosion process area, in Bauru city, inland of São Paulo State, Brazil. The objective is to characterize the local soil and define the major causing factors for the erosion process evolution, which initiated with deforestation, soil sealing and discharge of pluvial and sewer water. The erosion turned huge with an urban setting with inappropriate design and no drainage infrastructure jobs. This phenomenon was studied by field observation, in situ and laboratory tests to establish a mechanism to explain the erosion process. Young residual soils of sandstone, mature residual soil weathered by pedogenetic processes and transported soils occur in the site. Characterization, erodibility and mechanical tests were carried out on three typical and distinct soils as well as SPT testing. The soils were classified as clayey sand with variable colors, almost always in unsaturated condition. Erodibility test results from three different methods classified the soils as very high erodibility, and Nogami and Villibor (1979) method was the most interesting for the studied soil. Suction plays an important role in the shear strength and soil saturation significantly reduced cohesion. Water is the trigging agent and the major responsible for the erosive process evolution, even by superficial or groundwater flow. The flow inside the soil mass changes the grain size distribution of the soil and also modifies their properties. The evolution mechanism begins increasing the soil water content by the rain and it can, in some places, reach soil saturation reducing shear strength turning cohesion equal to zero. Since the soil is saturated and with water flow, it can loose its structure by piping, so it's easily detached and dragged along causing slope instability and evolution of erosion process.
\end{abstract}

Keywords: erosion process, characterization, evolution mechanism. 


\section{LISTA DE FIGURAS}

Figura 1. Feições erosivas do tipo sulcos (Camapum de Carvalho et al., 2006) ......................................... 4

Figura 2. Vista geral de feições erosivas do tipo ravina (Ferreira, 2004) ......................................................5

Figura 3. Feição erosiva do tipo voçoroca em Bauru (SP) .......................................................................

Figura 4. Representação do efeito da cobertura vegetal no processo erosivo (Prandini et al., 1976 apud

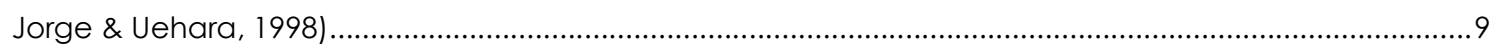

Figura 5. Classificação das encostas (Troeh, 1965 apud Moreira \& Pires Neto, 1998) ................................ 10

Figura 6. Representação esquemática de modelo evolutivo de erosão em $\vee$ e U (Camapum de

Carvalho, 2005)

Figura 7. Detalhe da rampa do ensaio Inderbitzen com o anel fixado (Fragassi \& Marques, 2001) .........22

Figura 8. Sistema com simulação do impacto da gota de chuva (Freire, 2001) .......................................24

Figura 9. Gráfico para avaliação da erodibilidade do solo segundo proposta de Nogami \&Villibor (1979)

Figura 10. Equipamento do ensaio de penetração de cone (Alcântara \& Vilar, 1998) ............................25

Figura 11. Gráfico para avaliação da erodibilidade do solo sugerido por Alcântara \& Vilar (1998) ........26

Figura 12. Principais curvas de retenção de água para diferentes tipos de solos (Rodrigues, 2007) .........35

Figura 13. Principais áreas de processos geodinâmicos em São Paulo (IPT) .............................................37

Figura 14. Zonas de susceptibilidade à erosão em Bauru (IPT, 1994) .......................................................42

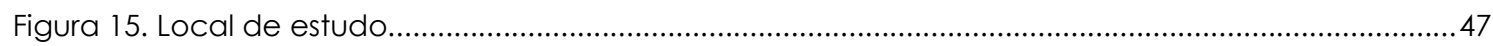

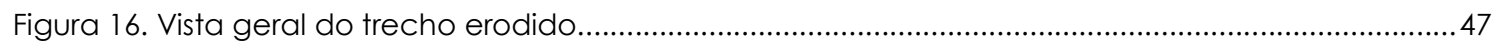

Figura 17. Ramificação da erosão em 2003 (Corghi, 2005) .......................................................................48

Figura 18. Ramificação fechada com entulho e lixo orgânico em 2006 .................................................48

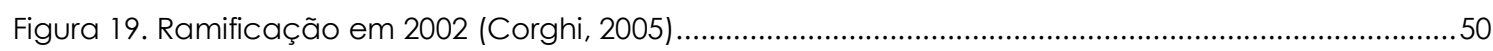

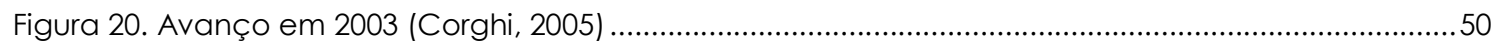

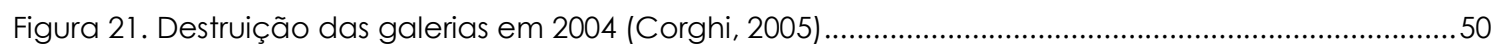

Figura 22. Início do aterramento em 2004 (Corghi, 2005) .....................................................................50

Figura 23. Ramificação aterrada e coberta com camada de solo em 2005 (Corghi \& Giacheti, 2005) .51

Figura 24. Remoção da camada superficial de solo da região aterrada em 2006 ..................................51

Figura 25. Gabião destruído pela ação da água em 2003 (Corghi \& Giacheti, 2005) ...............................51

Figura 26. Início das obras em 2004 (Corghi \& Giacheti, 2005) ..............................................................52

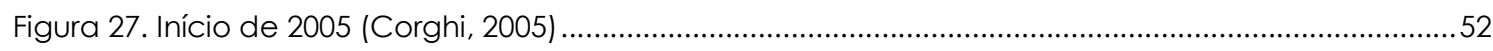

Figura 28. Canal aberto no início de 2005 (Corghi, 2005) ......................................................................52

Figura 29. Assoreamento do canal e erosão do talude no final de 2005 .................................................52

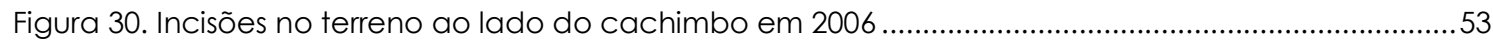

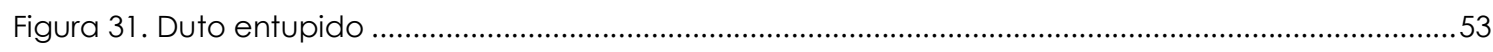

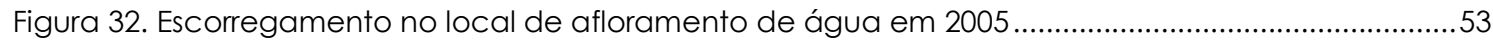

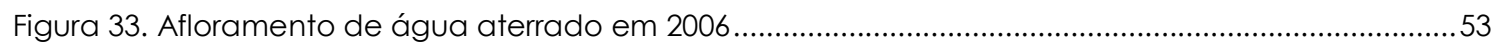

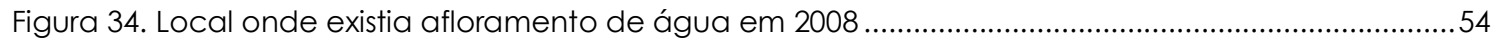

Figura 35. Localização dos ensaios de campo, das amostras coletadas e dos pontos onde foram feitos

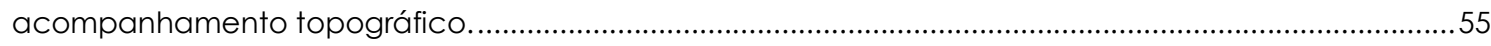


Figura 36. Local de coleta da amostra 1 - Voçoroca ..............................................................................5

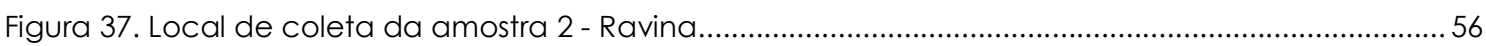

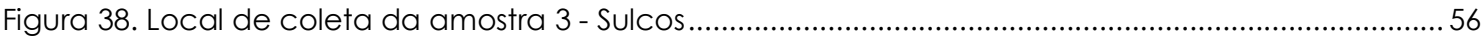

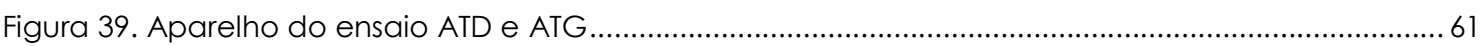

Figura 40. Saturação dos corpos-de-prova e detalhe do papel filtro em contato com o corpo-de-prova.

Figura 41. Ensaio de funil de placa porosa para determinação da curva característica do solo............64

Figura 42. Equipamento Inderbitzen construído

Figura 43. Representação da perda de solo versus tensão cisalhante aplicada no ensaio Inderbitzen (Lafayette et al., 2005) .68

Figura 44. Ensaio de cone e heterogeneidade da amostra 3 (superior) e 1 (inferior) ..............................70

Figura 45. Realização das sondagens de simples reconhecimento na área de pesquisa ....................... 71

Figura 46. Curvas granulométricas da amostra 1 com e sem defloculante............................................ 73

Figura 47. Curvas granulométricas da amostra 2 com e sem defloculante...............................................73

Figura 48. Curvas granulométricas da amostra 3 com e sem defloculante...........................................73

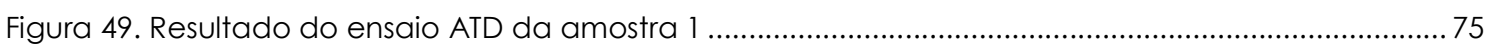

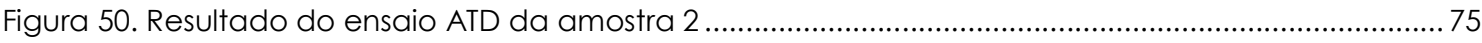

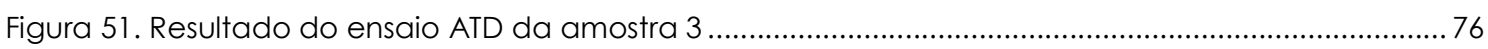

Figura 52. Resultado característico do ensaio ATG para uma das amostras estudadas ......................... 76

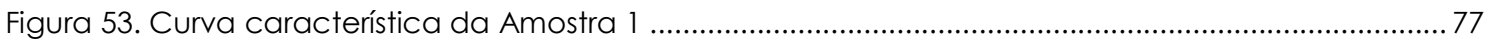

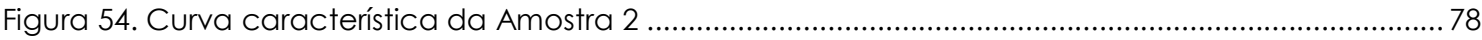

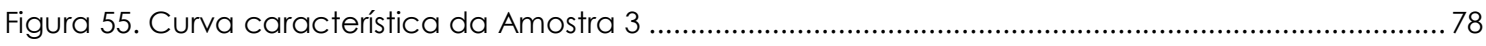

Figura 56. Resultados do ensaio Inderbitzen para a amostra 1 .............................................................. 79

Figura 57. Resultados do ensaio Inderbitzen para a amostra 2 ............................................................ 79

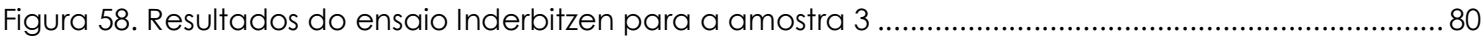

Figura 59. Resultado típico da curva de absorção de água para determinação do coeficiente angular

Figura 60. Resultado típico da curva compressão edométrica na condição natural e inundada (Am. 3)

Figura 61. Determinação do tempo para ocorrer $100 \%$ do adensamento primário (†100) com base no resultado do ensaio de compressão edométrica da amostra 3 para tensão vertical de $100 \mathrm{kPa}$...........85

Figura 62. Curvas típicas do ensaio de cisalhamento realizado em uma das amostras ensaiadas ......... 85 Figura 63. Envoltória de resistência e respectivos parâmetros de resistência para a amostra 1 na condição natural e inundada

Figura 64. Envoltória de resistência e respectivos parâmetros de resistência para a amostra 2 na condição natural e inundada .86

Figura 65. Envoltória de resistência e respectivos parâmetros de resistência para a amostra 3 na condição natural e inundada .87

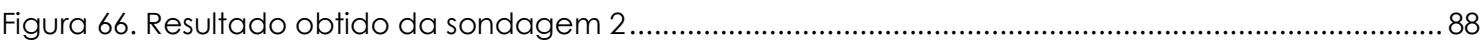

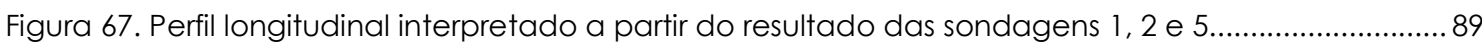

Figura 68. Amostras de solos em cápsulas de umidade coletadas na sondagem 1 ................................89 
Figura 69. Representação esquemática da evolução do processo erosivo no local 1 da área estudada

Figura 70. Escorregamentos sucessivos observados em campo...........................................................

Figura 71. Superfície resistente do talude no seu topo ...........................................................................92

Figura 72. Solo escorregado no pé do talude no local de levantamento topográfico 2.........................92

Figura 73. Formação de canais devido ao fenômeno de erosão interna retrogressiva ..............................93

Figura 74. Gráficos para interpretação do ensaio Inderbitzen para a amostra 1 ...................................98

Figura 75. Gráficos para interpretação do ensaio Inderbitzen para a amostra 2 .....................................98

Figura 76. Gráficos para interpretação do ensaio Inderbitzen para a amostra 3 ....................................99

Figura 77. Ábaco com resultados dos ensaios de absorção de água para avaliação da erodibilidade

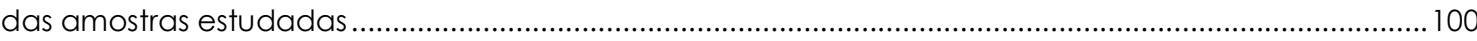

Figura 78. Ábaco com resultados dos ensaios de penetração de cone para avaliação do grau de

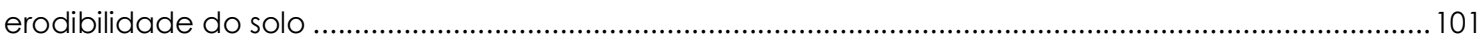

Figura 79. Influência da sucção na resistência para a amostra 1 ............................................................... 103

Figura 80. Influência da sucção na resistência para a amostra 2 ........................................................ 103

Figura 81. Influência da sucção na resistência para a amostra 3 ........................................................... 103

Figura 82. Perfil transversal interpretado a partir do resultado das sondagens ..................................... 105

Figura 83. Variação da granulometria ao longo do perfil transversal ...................................................... 106

Figura 84. Variação do pH ao longo do perfil transversal à erosão ........................................................ 107

Figura 85. Perfis de sondagem obtido a partir da sondagem 2 ........................................................ 108

Figura 86. Escorregamento em fatias devido ao fluxo de água na base do talude no local de coleta da amostra 1 109

Figura 87. Representação do avanço do processo erosivo por mês observado com levantamentos topográficos em ponto mais crítico do Local 1 ..................................................................................... 110

Figura 88. Representação da precipitação acumulada por mês no local estudado .............................. 110

Figura 89. Escorregamento por alívio de pressão e solapamento da base .............................................. 112

Figura 90. Representação do mecanismo de instabilização ............................................................... 114 


\section{LISTA DE TABELAS}

Tabela 1 - Quantidades dos materiais utilizadas no método de Pejon (1992)

Tabela 2 - Limites de consistência das amostras estudadas..........................................................

Tabela 3 - Resultados de massa específica dos sólidos..................................................................

Tabela 4 - Resultados do ensaio de adsorção de azul de metileno.............................................. 75

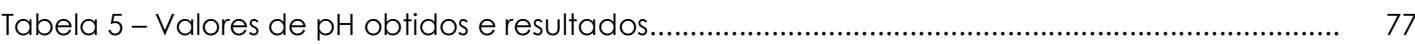

Tabela 6 - Resultados dos ensaios de absorção para cada amostra ensaiada............................ 81

Tabela 7 - Resultados do ensaio de penetração de cone.............................................................

Tabela 8 - Tensão de pré-adensamento para as amostras nos estados natural e inundado........ 83

Tabela 9 - Parâmetros de resistência para as três amostras ensaiadas na condição natural e inundada

Tabela 10 - Classificação das amostras de solo estudadas.

Tabela 11 - Ïndices físicos do solo.

Tabela 12 - Atividade dos argilominerais dos solos estudados e comportamento laterítico segundo classificação de Fabri (1994).

Tabela 13 - Parâmetros resultantes do ensaio Inderbitzen para as três amostras estudadas....... 


\section{SUMÁRIO}

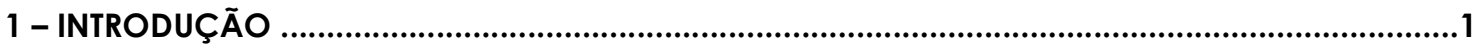

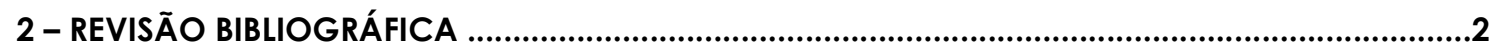

2.1 - Erosão

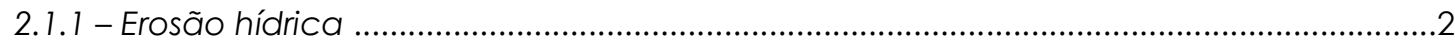

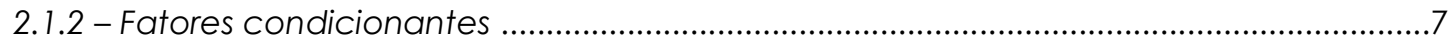

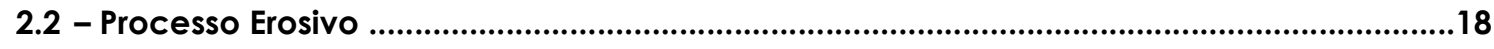

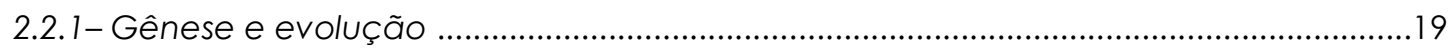

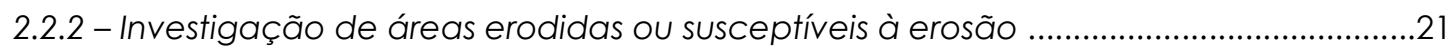

2.2.3 - Alguns estudos prévios sobre erosão .............................................................................29

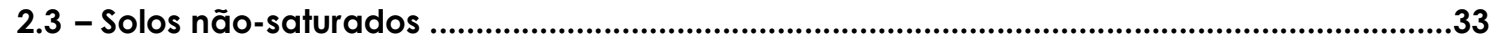

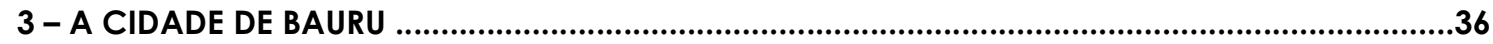

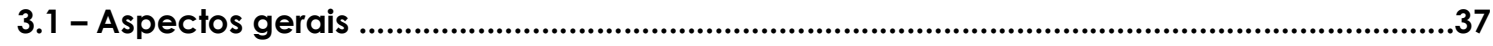

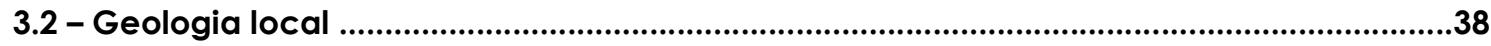

3.3 - Características geotécnicas do solo ..................................................................................42

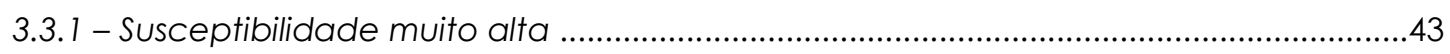

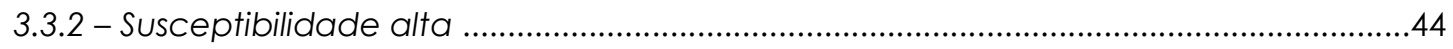

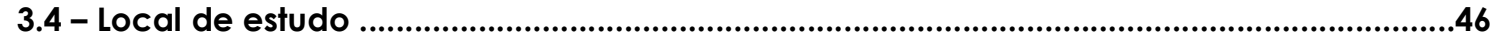

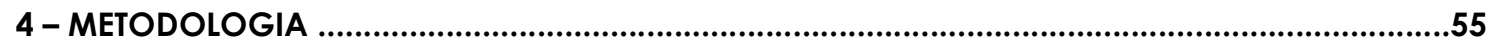

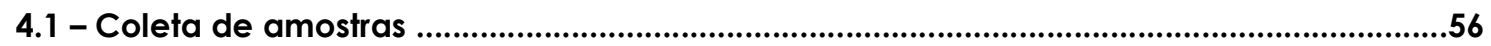

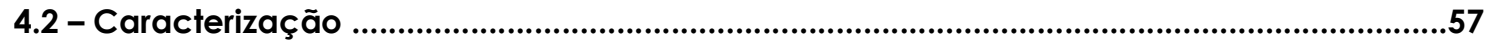

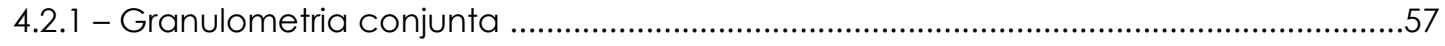

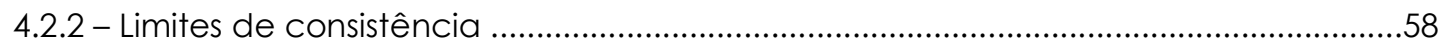

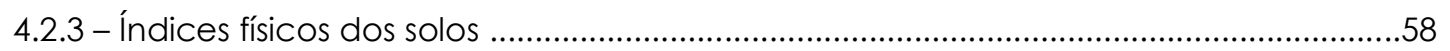

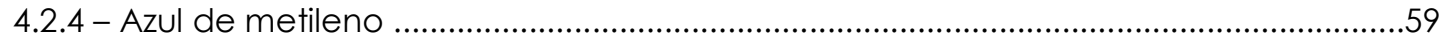

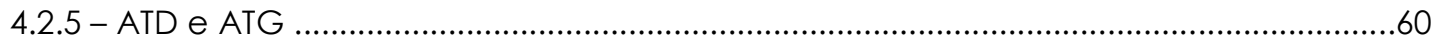

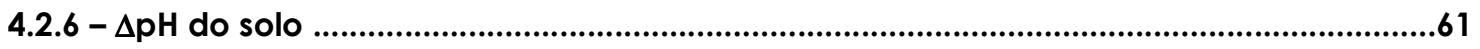

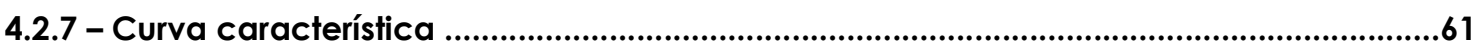

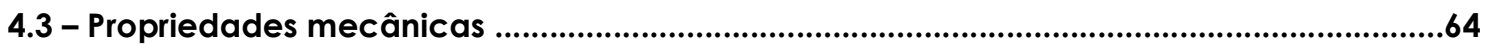

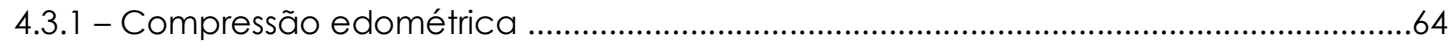

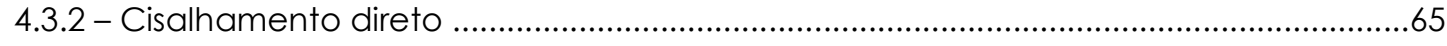

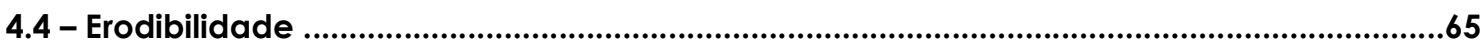

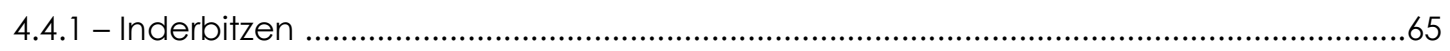

4.4.2 - Absorção de água e perda por imersão .......................................................................69 


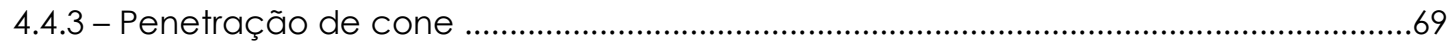

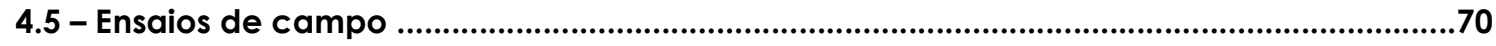

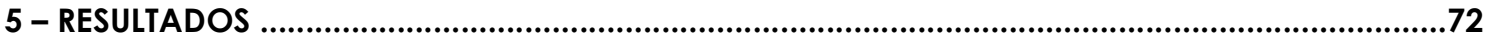

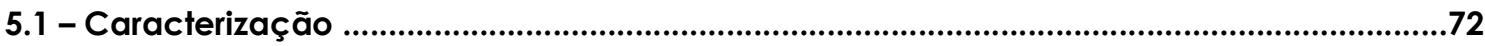

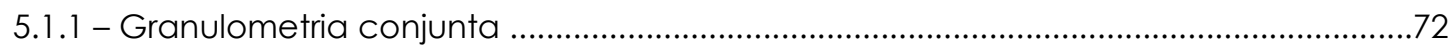

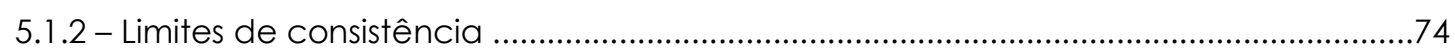

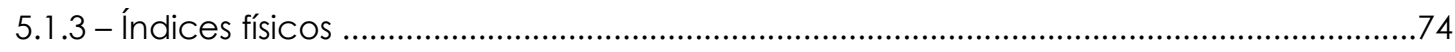

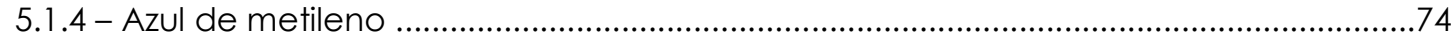

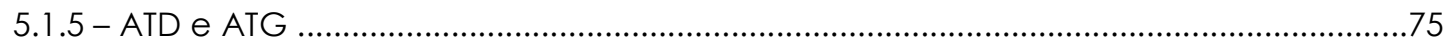

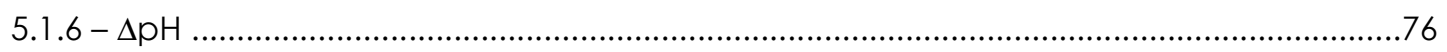

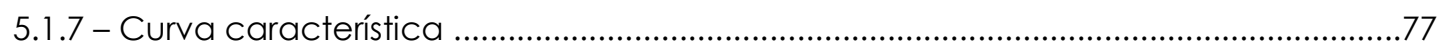

5.2 - Erodibilidade …........................................................................................................................78

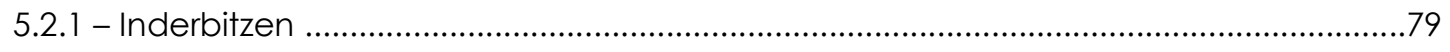

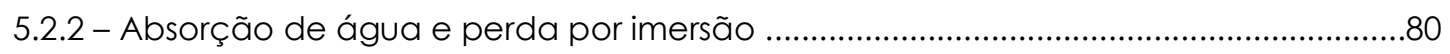

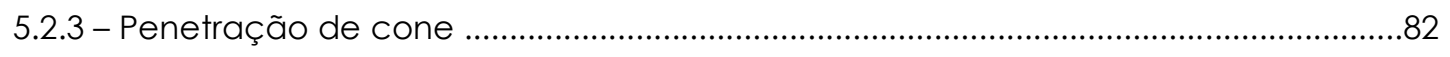

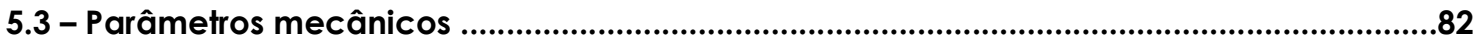

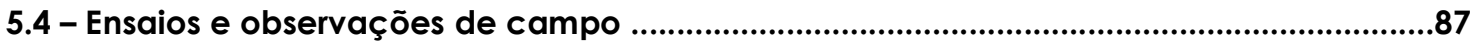

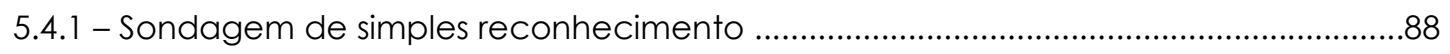

5.4.3 - Observação da evolução do processo erosivo no campo .......................................90

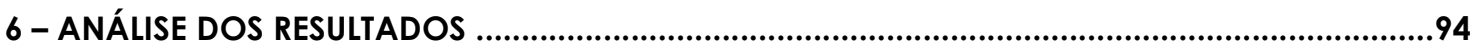

6.1 - Caracterização .......................................................................................................................94

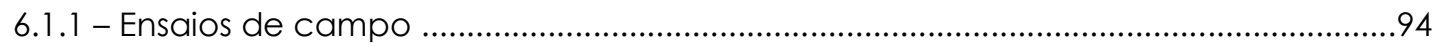

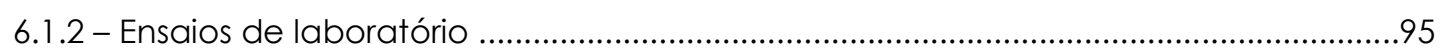

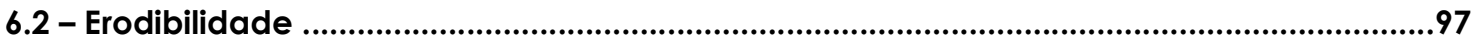

6.3 - Resistência e comportamento de solo não-saturado ...........................................................102

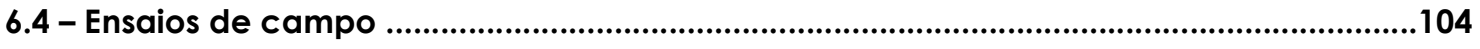

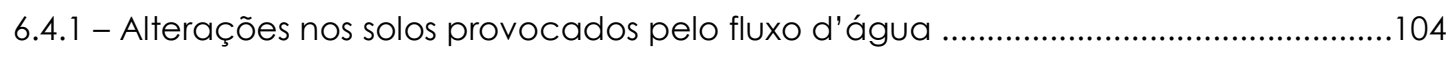

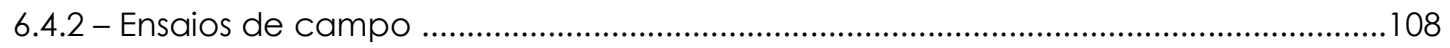

6.5 - Observações de campo ............................................................................................................109

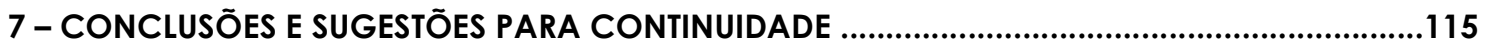

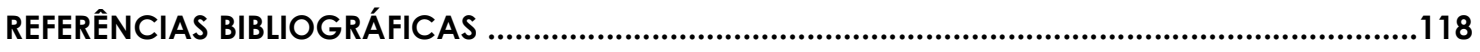





\section{1 - INTRODUÇÃO}

Um problema recorrente causado pela ação antrópica é a erosão urbana, que vem sendo estudada há tempos. Como não é possível chegar a um modelo representativo perfeito para todos os casos ocorridos, é importante avaliar os locais isoladamente e comparar em quais pontos os fenômenos erosivos são semelhantes ou divergentes.

Bauru, localizada no interior de São Paulo, sofre com fenômenos de erosão e, por isso, foi escolhida como local para o desenvolvimento desse trabalho. O principal fator que influencia o início do processo erosivo na cidade é a ação antrópica, que ocorre através do desmatamento e da impermeabilização do solo devido à expansão urbana.

Áreas de alta susceptibilidade à erosão associadas a sistemas de drenagem mau dimensionados são importantes na evolução do fenômeno. Segundo Corghi (2005), as medidas corretivas realizadas não levaram em conta as feições do terreno e, por isso, foram atingidas e destruídas. Esse fato foi verificado na execução dos aterros, utilizados somente para fechar as ramificações existentes, e dos taludes laterais ao leito do córrego, de grande inclinação de modo a não garantir a estabilidade.

Além disso, observa-se que na maioria dos locais afetados não houve preocupação com a influência das águas subsuperficiais, levando a ocorrência de novos escorregamentos. A falta de manutenção está contribuindo com a reinstabilização dos taludes de contenção, com a formação de novas incisões no terreno próximas às obras corretivas.

Dessa forma, o objetivo principal dessa pesquisa é investigar e caracterizar o solo encontrado na área em estudo e determinar quais são os principais fatores que atuam em favor da evolução do processo erosivo. Com o auxílio de observações de campo, ensaios de campo e laboratório, o processo erosivo foi estudado com o intuito de se explicar o mecanismo do fenômeno que ocorre no local. 


\section{2 - REVISÃo BIBLIOGRÁFICA}

\section{1- Erosão}

Erosão é o nome dado ao processo de desagregação e transporte de partículas de solo, rochas ou fragmentos causado pela ação da chuva, do vento, de organismos (animais e plantas) ou do gelo, que atua na expansão do material no qual se infiltra a água depois congelada (Salomão \& Iwasa, 1995 apud Infanti Junior \& Fornasari Filho, 1998).

Os fenômenos erosivos podem ser causados por fatores naturais (erosão natural) e por ação antrópica (erosão acelerada), como distinguem Infanti Junior \& Fornasari Filho (op. cit.). Os primeiros determinam a intensidade dos processos, destacando-se como mais importantes: a ação da chuva, a cobertura vegetal, o relevo, os tipos de solos e o substrato rochoso. Exemplos de ação antrópica são: o desmatamento, a forma de uso e ocupação do solo.

A diversidade de fatores causadores e agentes erosivos dificulta o estudo do processo, aliada ao fato de que as erosões, mesmo em regiões próximas, podem não apresentar mesma intensidade destrutiva ou abrangência.

\subsection{1 - Erosão hídrica}

A água é o principal fator dinâmico no processo erosivo, sendo responsável por sua gênese e evolução. A atuação da água se faz sentir de diversas formas conjuntamente, sendo as principais: ação erosiva da gota de chuva, lençol subterrâneo e escoamento superficial (Rodrigues, 1982).

No Brasil, os processos erosivos são provocados principalmente pela ação da água e acelerados pelo uso e ocupação do solo. Infanti Junior \& Fornasari Filho (op. cit.) explicam que o processo erosivo é deflagrado pela chuva através do impacto das gotas, que 
provoca a desagregação das partículas, e o escoamento superficial é responsável pela remoção e transporte.

Rodrigues (1982) escreveu que, com o impacto da gota da chuva, as partículas de solo têm o tamanho reduzido devido à sua desagregação e, além disso, são deslocadas através da saltitação. Algumas, quando em suspensão, podem infiltrar-se no solo, diminuindo a sua permeabilidade e, conseqüentemente, aumentando o escoamento superficial (Almeida Filho, 2000).

A interceptação do lençol freático, em associação às águas de superfície, acelera o processo erosivo. Pode ocorrer de forma pontual ou na forma de uma linha bem diferenciada, que representa o nível piezométrico local. As águas subsuperficiais são responsáveis pelo fenômeno de erosão retrogressiva (piping), que ocorre devido ao aumento do gradiente hidráulico e das forças de percolação na voçoroca, causando instabilização e carreando as partículas do solo. A liquefação dos sedimentos dos pés dos taludes também é uma conseqüência do fluxo subsuperficial.

O escoamento superficial é o grande responsável pelas alterações de caráter erosivo (Rodrigues, op. cit.). A parcela de água que escoa na superfície é classificada como laminar ou linear, dependendo do tipo de como se processa o escoamento superficial (Infanti Junior \& Fornasari Filho, 1998).

\subsubsection{1 - Erosão laminar}

A erosão laminar é causada pelo escoamento difuso das águas das chuvas, resultando na remoção progressiva e uniforme dos horizontes superficiais do solo (DAEE/IPT, 1990), lateralmente ou em pequenos filetes, que são evidenciados por tonalidades mais claras dos solos e pelo abaixamento da cota do terreno. Geralmente ocorre em locais com pouca ou nenhuma vegetação. Não há um limite definido que separe a erosão laminar da linear (Fendrich et al., 1997). 


\subsubsection{2 - Erosão linear}

Já a erosão linear é causada pela concentração das linhas de fluxo das águas de escoamento superficial (DAEE/IPT, 1990), que comanda o desprendimento e o transporte das partículas do solo, causando pequenas incisões na superfície do terreno em forma de sulcos, que se aprofundam formando ravinas e, posteriormente, voçorocas (Infanti Junior \& Fornasari Filho, 1998). Há várias classificações que separam os estágios da erosão linear, pois há grande divergência entre os autores sobre suas dimensões.

\section{$\underline{\text { Sulcos }}$}

Ocorrem posteriormente à erosão laminar e apresentam forma de filetes muito rasos, além de possuir ruptura das bordas na superfície do terreno (Ferreira, 2004; DAEE/IPT, 1990). Caracteriza-se pela presença de sulcos sinuosos que se localizam ao longo do declive (Figura 1). Esse tipo erosivo pode, algumas vezes, não ser percebido até que interferir no preparo do solo em áreas agrícolas ou em novos loteamentos e ruas sem pavimentação.

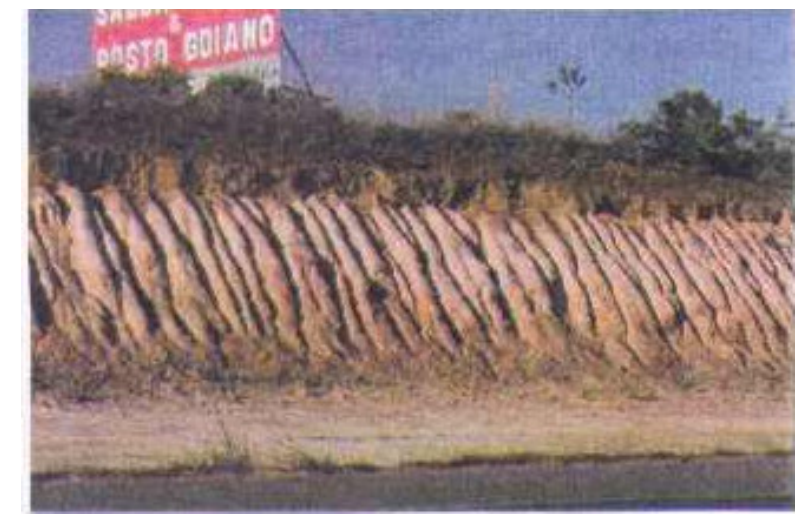

Figura 1. Feições erosivas do tipo sulcos (Camapum de Carvalho et al., 2006)

\section{$\underline{\text { Ravinas }}$}

Define-se ravinas como sulcos profundos ao longo do declive, que apresentam de forma alongada e seção em "V", não atingindo o nível d'água (Figura 2). Normalmente, não possuem ramificações e seu alargamento ocorre através de movimentos de massa gravitacionais (escorregamentos), ocasionando o avanço da erosão (Canil et al., 1995). Vilar 
(1987) cita que a maior concentração de ravinas, bem como de voçorocas, que ocorre no estado está na porção Centro-Oeste, onde aparecem as rochas do grupo Bauru, comumente capeadas por sedimentos cenozóicos incoerentes (latossolos e solos podzólicos).

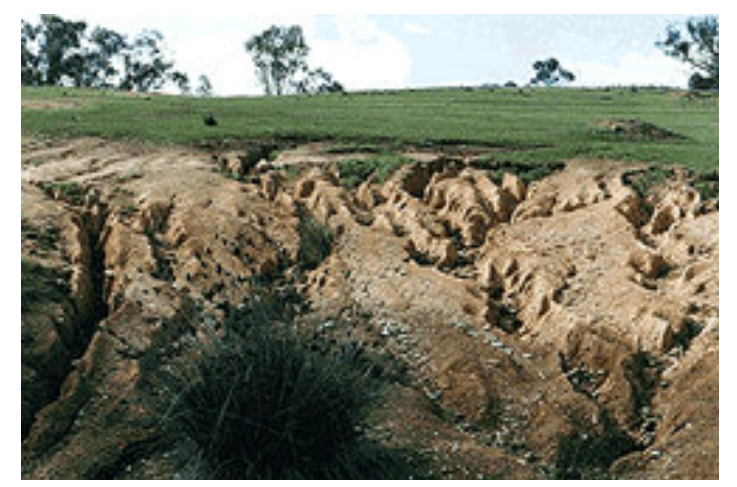

Figura 2. Vista geral de feições erosivas do tipo ravina (Ferreira, 2004)

\section{Vocorocas}

Com a formação e aprofundamento das ravinas, pode-se observar uma somatória de processos erosivos pela ação concomitante das águas superficiais e subsuperficiais, fazendo com que o ravinamento atinja grandes dimensões, dando-se a esse fenômeno o nome de voçoroca (Infanti Junior \& Fornasari Filho, 1998). No início do processo do voçorocamento é difícil distinguir ravinas, entretanto, em estágios mais avançados, certas características permitem fácil distinção, tais como: a presença comum de água no fundo da voçoroca, sua forma, com tendências tanto para alargar-se e aprofundar-se, e o desenvolvimento de ramos laterais.

A voçoroca é o tipo erosivo mais avançado, possui grande variabilidade espacial e temporal e geralmente se instala em terrenos de baixa declividade. Após atingir o lençol freático, adquire uma seção em U devido aos fenômenos de piping e transporte fluvial de massas recém descalçadas (Guidicini \& Nieble, 1976 apud Rodrigues, 1982).

Fendrich et al. (1997) considera a voçoroca um processo erosivo semi-superficial de massa, face ao fenômeno global da erosão superficial e ao desmonte de maciço de solos dos taludes, ao longo dos fundos de vale ou de sulcos realizados no terreno. 
O escorregamento se processa através da movimentação de massas achatadas, em taludes com inclinação de $60^{\circ}$ a $80^{\circ}$ (Guidicini \& Nieble, op. cit.). Rodrigues (1982) explica que sua ocorrência pode estar relacionada a pontos particulares, como contatos, fraturas, zonas de menor coesão ou de maior gradiente piezométrico e a granulometria do solo onde se desenvolve. Além disso, o recente rebaixamento no nível da base da voçoroca pode ser a causa original do aumento do gradiente, resultando numa situação propícia para o desenvolvimento do piping. Rodriques (op. cit.) também salienta que esse tipo erosivo é importante no alargamento da feição, uma vez que a liquefação nos sopés do talude provoca solapamentos e escorregamentos em fatias. Os sedimentos deslocados são facilmente carregados pelas águas superficiais.

Nas voçorocas, a seqüência do processo de aprofundamento e alargamento resulta numa erosão remontante, que caminha em direção ao divisor de águas da bacia e, em alguns casos, a uma ramificação. Numa fase senil, a remoção do material é menor e notase uma estabilização gradual do leito, em conjunto com um pequeno curso d'água em seu interior e o crescimento de vegetação. O processo tende a se estabilizar quando o leito atinge o nível de base local, em geral comandado pela rede de drenagem ou por substratos rochosos mais resistentes.

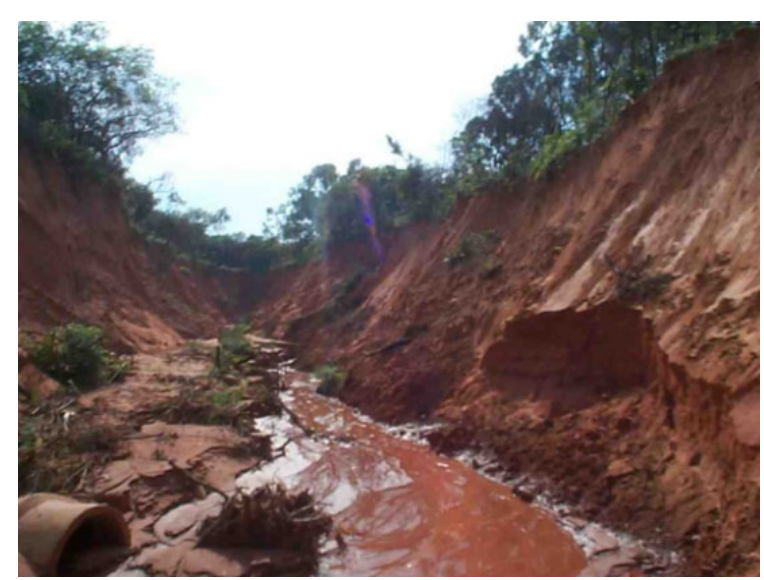

Figura 3. Feição erosiva do tipo voçoroca em Bauru (SP) 
Rodrigues (1982), em seus resultados, salientou a ocorrência de um pequeno aumento da porcentagem de finos nesse tipo erosivo em profundidades crescentes, sugerindo o carreamento de partículas através do arcabouço arenoso da superfície para o interior do maciço, devido à ação das águas percolantes.

Segundo Ferreira et al. (1993) é muito comum no Estado de São Paulo encontrar taludes formados em sua parte mais superficial por solos mais evoluídos pedologicamente, como os latossolos e, inferiormente, por solos saprolíticos. Embora não se possa generalizar, já que existem solos lateríticos com baixa resistência à erosão e nota-se um comportamento diferenciado entre os horizontes e uma característica comum é a notável capacidade dos horizontes laterizados de resistir às solicitações erosivas, quando comparado aos horizontes saprolíticos subjacentes.

Um aspecto importante da exposição dos solos lateríticos é o crescente ganho de resistência superficial com o tempo, proporcionado por fenômenos químicos de superfície, como a deposição de sílica devida à evaporação da água percolante. Além disso, ocorrem também fenômenos de endurecimento dos materiais finos e óxidos que se encontram misturados na fração areia desses solos. Entretanto, nos horizontes saprolíticos não se nota esse benefício além de haver mecanismos subsidiários que agravam a erosão, como, por exemplo, a expansão e a contração devidas aos ciclos de umedecimento e secagem e às flutuações de temperatura.

\subsection{2 - Fatores condicionantes}

São vários os fatores naturais para o desenvolvimento de sulcos para ravinas e posteriormente as voçorocas, destacando-se a chuva, o tipo de cobertura vegetal, o relevo, o solo e a natureza do substrato rochoso. Tais fatores não podem ser entendidos como independentes no estudo do fenômeno erosivo, devido a vários desdobramentos e/ou composições possíveis.

Pode-se dividir os condicionantes principais em: antrópicos, que englobam o desmatamento e formas de uso e ocupação do solo, e naturais. Os primeiros são 
responsáveis pelo início do processo erosivo imediatamente ou logo após sua ação, enquanto os naturais determinam sua intensidade.

Ellison (1947, apud Alcântara \& Vilar, 1998) descreve como agentes erosivos da chuva o impacto da gota no solo e o escoamento superficial. Corroborando Ellison, Nogami \& Villibor (1995) explicam que a erosividade é caracterizada, sobretudo, pela chuva atuando na superfície exposta. O efeito das chuvas é complexo e um dos fenômenos principais é o impacto das gotas, que causa a fragmentação dos agregados, que faz com que o seu deslocamento seja facilitado. Quando a quantidade de água é maior que a capacidade de infiltração no solo, a lâmina d'água resultante pode arrastar os grãos, ocasionando a erosão laminar. Também ressaltam que há uma grande variedade de tipo de formas erosivas encontradas em regiões tropicais, nas quais predomina a ausência de tratamento a fim de minorar ou eliminar os efeitos erosivos e desagregações superficiais. E que a identificação desses tipos tem importância na determinação do fenômeno ocorrido, que muitas vezes condiciona o procedimento de controle da erosão.

Camapum de Carvalho (2005) estudou a formação de erosões tipo ravina e voçoroca (lineares) em áreas urbanas, complementando que a formação se deve principalmente pelo lançamento indevido de águas superficiais em locais desprovidos de sistemas de drenagem adequados. O autor cita que as formas de tratamento utilizadas no controle dos processos erosivos normalmente fracassam, pois não consideram as características geológico-geotécnicas do local e pelo fato da evolução ocorrer em tempo relativamente curto.

\subsubsection{1 - Condicionantes naturais}

\section{$\underline{\text { Vegetação }}$}

A existência de cobertura vegetal é importante para a proteção contra o impacto de gotas de chuva, a dispersão e perda de energia das águas de escoamento superficial, o aumento da infiltração devido à maior porosidade do solo causada pelas raízes e aumento 
da capacidade de retenção de água por efeito da produção e incorporação de matéria orgânica pelo solo, como mostrado na Figura 4. O equilíbrio entre vegetação e solo é perdido com o desmatamento, que altera o balanço hídrico com o aumento do escoamento superficial e da infiltração, pois a água atinge diretamente o solo. Com o tempo, a infiltração reduz devido à saturação parcial do terreno, aumentando o escoamento superficial.

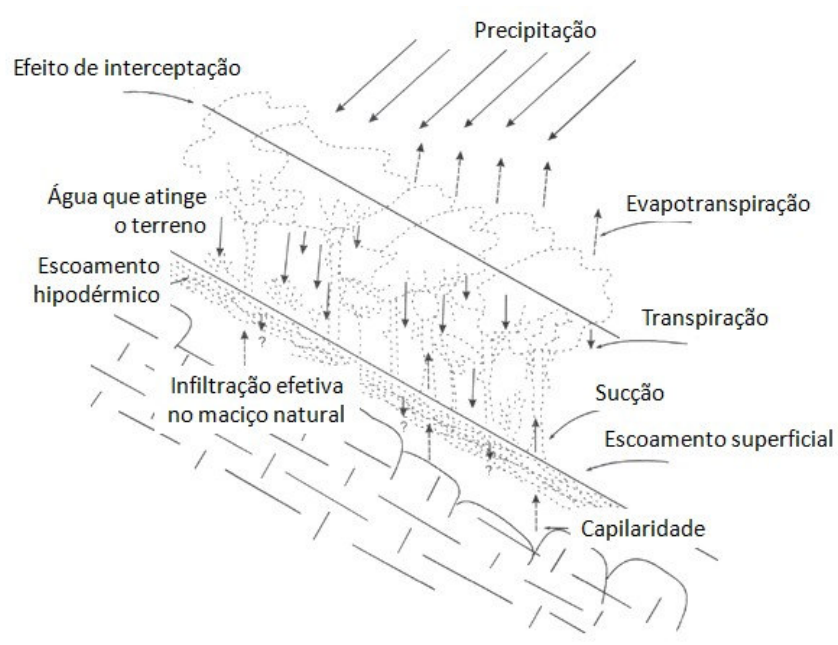

Figura 4. Representação do efeito da cobertura vegetal no processo erosivo (Prandini et al., 1976 apud Jorge \& Uehara, 1998)

Cabe ainda à vegetação a função de reter e aglutinar o solo por ação das raízes, o que implica um aumento da coesão aparente. Trata-se então de uma proteção mecânica, que inclusive contribui para deter outros processos de instabilização de maciços, como escorregamentos. O aumento da infiltração gera um aumento nos gradientes hidráulicos, sendo responsáveis pelo desencadeamento do fenômeno de erosão interna retrogressiva (piping).

\section{$\underline{\text { Relevo }}$}

Além da vegetação, existe uma estreita relação entre a topografia e a erosão. A influência do relevo ocorre, principalmente, pela declividade e comprimento da rampa, que interferem na velocidade do escoamento superficial (Infanti Junior \& Fornasari Filho, 
1998). Assim, nos locais em que esses fatores são maiores, a velocidade do fluxo também é maior, ocasionando um aumento da capacidade erosiva. As formas do relevo devem ser analisadas porque há uma relação entre o espaçamento das linhas de talvegue, que refletem a densidade da drenagem, e a profundidade do encaixamento dos canais com a tipologia e a declividade das encostas, como na Figura 5.

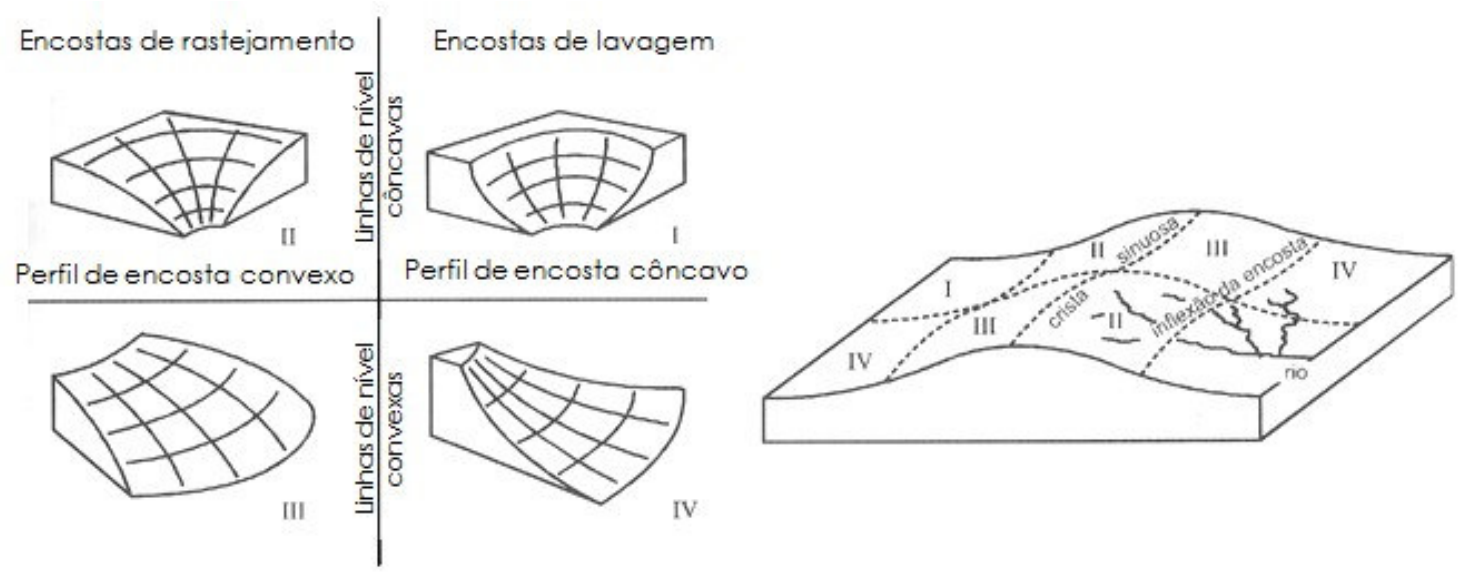

Figura 5. Classificação das encostas (Troeh, 1965 apud Moreira \& Pires Neto, 1998)

A superfície convexo-côncava de um talude mostra uma pronunciada erosão no trecho convexo, à medida que diminuem as declividades, no trecho de transição e no côncavo, ocorre deposição. A evolução dos perfis ao longo do tempo mostra que a tendência dos perfis convexo e retilíneo é tornarem-se côncavos com taxas decrescentes de erosão ao longo do tempo. Na superfície côncava a forma se mantém, ocorrendo apenas variação na curvatura em algumas posições. O conhecimento da influência da forma da encosta sobre a erosão pode trazer implicações práticas relevantes no projeto de taludes e superfícies onde a principal solicitação advenha da erosão pela chuva, proporcionando uma forma conveniente para a superfície, pode-se minimizar os efeitos erosivos. Já na encosta côncava, é possível verificar que o sedimento tende a se depositar nos trechos onde ocorre redução de declividade, devido à redução da capacidade de transporte do fluxo. Há uma tendência à evolução para um perfil côncavo, com redução da carga de sedimento erodida ao longo do tempo, o que leva a uma idéia de um perfil de 
equilíbrio para as encostas sujeitas á erosão pela chuva, que pode variar dependendo do local e suas condições (Vilar, 1987).

Vilar (op. cit.) também analisou que, para superfícies com inclinações superiores a 33\%, dependendo da densidade do solo, observou-se que o destacamento alcança um máximo e depois decresce com o aumento da inclinação. A erosão total de uma área tende a crescer com a distância, visto que as vazões aumentam. Esse acréscimo de erosão deve estar associado ao acréscimo da erosão nos sulcos, já que se tem observado que a erosão nas áreas inter-sulcos se mantém aproximadamente constante com a distância.

Segundo Almeida Filho (2000), no território paulista, os latossolos apresentam declividades suaves, porém com grandes comprimentos de rampa, enquanto os solos de $B$ textural apresentam declividades mais acentuadas e curtos comprimentos de rampa.

\section{Ação da Água}

Alcântara e Vilar (1998) comentam que a erosão causada pela ação da água é um conjunto de fatores que causam destacamento do solo e seu transporte, podendo ser influenciada pelo homem e ligada ao clima. Além disso, consta que a erodibilidade é um dos fatores que contribuem para o início e evolução do fenômeno.

O processo erosivo do solo é deflagrado pelas chuvas ou concentração de água, através dos seguintes mecanismos: impacto, que provoca a desagregação das partículas, remoção e transporte pelo escoamento superficial, e a deposição dos sedimentos produzidos, formando depósitos de assoreamentos (Infanti Junior \& Fornasari Filho, 1998).

Vilar (1987) explica que a ação fundamental da gota consiste em minar a resistência do solo e deixar as partículas soltas, de forma que o fluxo pode facilmente levá-las sem grande gasto de energia. O trabalho erosivo é máximo quando o solo está recoberto por uma película de água de espessura igual ao diâmetro seu diâmetro. A gota ao chocar-se contra a superfície do solo destaca partículas e as movimenta. Além disso, o impacto da gota pode provocar a compactação e o selamento da superfície. A água que atinge o solo infiltra-se e ao ser superada a capacidade de infiltração do solo, principia o escoamento 
superficial, que apresenta feições extremamente complexas. Em pequenas áreas, o fluxo superficial movimenta-se como uma película praticamente uniforme na direção do maior gradiente, que pode ser tanto para jusante, como para as laterais. Pequenas variações de cotas e inclinações prontamente obrigam o fluxo a se concentrar, primeiramente segundo minúsculos filetes e, à medida que aumenta a vazão, segundo micro-canais ou sulcos.

As grandes concentrações de fluxo ainda constituem um processo dominante, porém nem todo o sedimento disponível para transporte origina-se do escoamento superficial. Escorregamentos de taludes e a ação da água subterrânea, dentre outros fatores, comumente encontram-se como fornecedores de sedimento nas voçorocas.

Quando o processo erosivo se encontra em um estágio avançado, verifica-se a existência de dois tipos de fluxo, o superficial e o subterrâneo, descritos por Ferreira et al. (1993).

- Fluxo superficial: resultante da água não infiltrada no solo. A impermeabilização da superfície do terreno contribui para o aumento desse tipo de fluxo e início do processo erosivo.

- Fluxo subterrâneo: o piping caracteriza-se como erosão interna que provoca remoção de partículas do interior do solo, formando "tubos" vazios que provocam colapsos e escorregamentos laterais do terreno, alargando a voçoroca, ou criando novos ramos. Sua influência é importante no alargamento da feição erosiva devido à ocorrência de movimento de areia, pela liquefação nos sopés dos taludes, no interior da erosão, provocando solapamentos e escorregamentos em fatias, pois as forças de percolação arrastam partículas de solo com avanço remontante. O fluxo subterrâneo usualmente não é considerado nos projetos de obras de contenção de voçorocas, sendo por isso responsável pelo insucesso de várias obras de engenharia. 


\section{Substrato Rochoso}

As características litológicas associadas à intensidade do intemperismo e à natureza da alteração e grau de fraturamento condicionam à suscetibilidade do material à erosão. As formações geológicas sedimentares, cujas coberturas pedológicas correspondem a materiais arenosos (solos podzólicos, latossolos ou depósitos alúvio-coluvionares), são as principais áreas de ocorrência de boçorocas no país (Infanti Junior \& Fornasari Filho, 1998).

$\underline{\text { Solo }}$

A erodibilidade do solo indica o grau de facilidade com que as partículas de solo destacam-se e são transportadas e é um dos fatores que contribuem para a erosão do solo, principalmente pela ação da água. Rodrigues (1982) separou a atuação da água em 3 formas: ação erosiva da gota de chuva, escoamento superficial e lençol subterrâneo. Os dois, de uma forma simplificada, variam em sentidos contrários, isto é, quanto maior a destacabilidade, menor a transportabilidade das partículas e vice-versa. Pode-se associar a destacabilidade do solo às forças de ligação das partículas, características de solos finos, enquanto a transportabilidade estaria mais associada às características físicas do sedimento, tais como tamanho e forma das partículas e suas propriedades in situ.

São poucos os métodos de análise da erodibilidade, pode-se citar como mais utilizadas as metodologias propostas por: Inderbitzen (1961), que avalia a erosão causada por escoamento laminar; Nogami \& Vilibor (1979), com o ensaio de absorção de água e Alcântara e Vilar (1998), com as modificações no ensaio de penetração de cone.

Alcântara \& Vilar (1998) avaliaram a erodibilidade de alguns solos do estado de São Paulo e concluíram que os métodos de análise (penetração de cone, absorção de água e compressão simples) se mostraram eficazes, pois conseguiram separar amostras com diferentes comportamentos frente à erosão. Além disso, os autores também verificaram que o ensaio de penetração de cone permitiu separar satisfatoriamente os solos erodíveis dos não erodíveis e que o mesmo destaca-se pela simplicidade e reprodutibilidade na execução dos testes. Assim, dividiram as amostras em dois níveis de erodibilidade: 
- Baixa a nenhuma - Aparência estável sem ocorrência de sulcos ou ravinamento em toda a face do talude. Presença de sulcos lineares subparalelos de pequena profundidade (aproximadamente $10 \mathrm{~cm}$ ). O efeito erosivo do escoamento d'água sobre a face do talude pode ser observado na sua base.

- Alta - Intensa remoção do solo, gerando cavidades de dimensões variadas e grandes sulcos. Presença de ravinas localizadas com forma similar aos sulcos, mas com profundidades que geralmente alcançam mais de um metro. Possibilidade de ocorrência de deslizamento das camadas sobrejacentes.

Porém, a erodibilidade do solo obtida por métodos indiretos, nem sempre é capaz de explicar o grande volume de sedimentos presentes às margens dos cursos d'água. Ensaios simples, que permitam avaliar mesmo que qualitativamente a erodibilidade dos solos, vêm sendo utilizados, entretanto, poucos apresentam uma abordagem geotécnica.

Fácio (1991) complementa que, devido ao grande número de variáveis que interferem na erodibilidade, sua correlação com propriedades e parâmetros geotécnicos isolados é de difícil execução.

Segundo Bertoni \& Lombardi Neto (1985, apud Infanti Junior \& Fornasari Filho, 1998), as principais propriedades que influenciam na erodibilidade destacam-se a textura, a estrutura e a permeabilidade. A textura, que representa o tamanho das partículas, influi na capacidade de infiltração e absorção d'água da chuva, interferindo no potencial das enxurradas no solo e na coesão entre partículas. A estrutura ou arranjo das partículas afeta a capacidade de infiltração, absorção e de arraste das partículas de solo. A permeabilidade determina a capacidade de infiltração da água. Em geral, solos com textura arenosa são normalmente porosos, o que permite uma alta infiltração de chuva e diminui o escoamento superficial. Porém, são mais facilmente erodidos, pois possuem pequena quantidade de argila.

Vilar (1987) explica que os sedimentos arenosos que recobrem vastas áreas do centro-sul do Brasil mostram-se extremamente afetados pela erosão acelerada. Tais sedimentos, bastante porosos, apresentam-se laterizados o que thes confere boas 
características mecânicas quando compactados. Porém, em condições naturais, ao ficarem desprotegidos de vegetação e à mercê das precipitações e dos escoamentos concentrados, sofrem intensamente os efeitos da erosão.

A espessura da camada de solo também é importante, pois solos rasos favorecem o surgimento de enxurradas pela rápida saturação dos horizontes superiores e solos arenosos, o que facilita a ocorrência do processo erosivo, apesar de apresentarem boa porosidade e menor escoamento superficial. Já em casos de chuvas prolongadas, grande parcela de horizontes do solo pode ser saturada, possibilitando o desenvolvimento de erosões de grande porte em locais de regime de escoamento concentrado.

No exame do perfil de solo, as variações na tonalidade da cor permitem determinar seus horizontes. A cor do solo reflete as variações dos conteúdos de matéria orgânica, sílica e compostos de ferro. A atividade biológica (animais e vegetais), em geral, escurece o solo pela acumulação de matéria orgânica. As migrações de argila e ferro podem torna o solo mais claro (horizonte de partida) ou mais avermelhado (horizonte de chegada), como explica Guerra et al. (2007).

\section{Argilominerais e Cimentação Superficial}

A presença de argila pode condicionar a um comportamento erosivo do solo, independente da ação da chuva. Ciclos de umedecimento e secagem, bem como variações de temperatura, levam à expansão e à retração de argilominerais presentes em certos solos, como os de natureza saprolítica, culminando com o destacamento dessas partículas do maciço.

Segundo Rodrigues (1982), no clima brasileiro, apesar da pluviosidade elevada, na superfície de materiais arenosos, tanto em solos como em rochas, ocorre uma cimentação das partículas de areia por sílica, óxidos e hidróxidos de ferro e argilominerais. A observação dos sedimentos modernos, não apenas em várias boçorocas como também em taludes de cortes de estradas, permite constatar a presença de crosta superficial que aumenta a resistência à erosão. O desenvolvimento dessa cimentação superficial se deve à 
mobilização da sílica e ferro pela água que percola o sedimento. A ascensão dessa água até a superfície do terreno, onde se deposita o material solúvel transportado, é devida a atuação conjunta dos fenômenos de capilaridade e evaporação. Ensaios de laboratório mostraram que este processo de cimentação superficial se desenvolve com relativa rapidez e ajuda a manter taludes acima da altura crítica.

Vilar (1987) complementa sobre a formação de agregados estáveis, compostos de partículas pequenas, como argilas e siltes, os grumos podem ser maiores e mais pesados que as partículas individuais. Assim, eles oferecem maior resistência ao transporte pelo fluxo. Além disso, grumos formados por argila e silte tendem a apresentar densidades próximas às das partículas individuais, enquanto nos grumos formados por partículas maiores, as densidades chegam a 2/3 das densidades das partículas isoladas.

Em relação à geoquímica dos solos, o pH é importante na absorção de cátions de argilas e matéria orgânica, em virtude da ligação preferencial dos íons de hidrogênio nas reações de troca. A alteração do pH atua efetivamente na estabilidade dos compostos dos solos, que, uma vez perdida, possibilita a ação dos processos erosivos (Guerra et al., 2007).

\subsubsection{2 - Condicionantes antrópicos}

Stein (1995) diz que as atividades humanas constituem o principal fator na deflagração dos processos erosivos, rompendo o equilíbrio natural do meio físico e fazendo com que a erosão natural local seja acelerada na busca de um novo equilíbrio.

Influencia a evolução da ação erosiva da água através do desmatamento, da queimada, da impermeabilização com a pavimentação de vias, ocupação do solo sem implantação de infra-estrutura e do lançamento de resíduos, causando danos à fauna, modificações na topografia, alterações hidrológicas e destruição de ecossistemas. Em zonas urbanas, os processos de erosão são causados principalmente pela concentração de águas de escoamento superficial, lançadas em talvegues desprovidos de sistemas adequados de drenagem, resultando em incisões na superfície do terreno, que podem evoluir. 
Dessa maneira, favorece o aparecimento de feições de ravinas e voçorocas, as quais são bastante freqüentes no Estado de São Paulo, tanto em áreas urbanas como em rurais. A indução dessa forma erosiva por obras como loteamentos e estradas é enorme, pois além de desproteger o solo, provocam concentrações de fluxo. Além disso, essas obras promovem mudanças drásticas no terreno através de cortes e aterros, expondo, em alguns casos, solos mais susceptíveis à erosão (Ferreira et al., 1993).

A ação antrópica é um dos fatores mais influentes no processo erosivo, pois usualmente provocam desequilíbrios que desencadeiam a erosão. Um exemplo é a construção de loteamentos, que engloba as ruas e as estruturas, pois há uma desproteção do solo e uma concentração de águas superficiais devido à diminuição ou inexistência de áreas de infiltração e à necessidade de canalizar o esgoto das estruturas locais. Quando há sistemas apropriados de condução das águas, o problema pode ter origem no ponto de lançamento das águas captadas. Os incrementos das vazões, por ocasião das chuvas intensas, aliados às alterações no nível freático, fazem com que a dinâmica do processo seja acelerada.

As formas de organização dos parcelamentos do solo são as principais desencadeadoras do processo de erosão, pela negligência de execução das obras de infra-estruturas devidas, de dissipadores de energia, de pavimentação de qualidade e de medidas preventivas que conservem o meio ambiente. $O$ traçado do arruamento comporta ruas inteiras em sentido perpendicular às curvas de níveis, que só recebem sistemas de drenagem na parte central, à medida que as águas pluviais descem essas "ladeiras", sua energia cinética aumenta, destruindo a rede de drenagem e a pavimentação. A parte alta dos loteamentos, tanto quanto as ruas horizontais, quase paralelas às curvas de níveis, ficam privadas de sistemas de drenagem na maioria dos casos. O destino final das águas das enxurradas é o fundo de vale, que passa a ser assoreado (Iwasa \& Fendrich, 1998).

Os custos para a correta reabilitação das áreas degradadas são muito elevados e, bem superiores aos custos da implantação de todas as obras de infra-estrutura preventivas necessárias. 
Corghi \& Giacheti (2005) citam que as maiores voçorocas ocorridas em Bauru são resultantes do processo de parcelamento que aconteceu no Período da "Cidade sem Limites", na década de 70. Os loteamentos afetados, em sua maioria, sem ou com implantação tardia de infra-estrutura, correspondiam ao modelo "ladeira abaixo". As primeiras áreas a serem afetadas pelo processo erosivo são as institucionais destinadas à região próxima às Áreas de Preservação Ambiental, onde são necessários gastos maiores com dissipadores de energia de águas pluviais. A manutenção e custeio dessas obras ficam a critério dos órgãos públicos, enquanto os empreendedores economizam com infraestrutura.

Ferreira (2004) explica que a erosão urbana, além de acompanhar o processo de consolidação da ocupação, apresenta-se dinâmica com grande variabilidade temporal e espacial. Portanto, a conscientização, principalmente dos administradores públicos, no sentido da importância dos estudos sobre erosão, é fundamental para a viabilização de novos loteamentos de forma adequada e responsável.

\section{2- Processo Erosivo}

A erosão é um problema grave que atinge um grande número de municípios brasileiros. Na região de Bauru, no interior do Estado de São Paulo, são encontrados solos arenosos resultantes das Formações do Grupo Bauru e Sedimentos Cenozóicos, bastante susceptíveis a fenômenos erosivos, motivo da existência de várias erosões urbanas de grande porte, provocadas pela inadequada ocupação do meio físico. Muitos municípios do Brasil apresentam um grave problema de degradação de suas áreas urbanas por conseqüência das erosões, devido ao seu enorme poder destrutivo, criando danos ao meio ambiente, situações de risco à população e patrimônios.

Segundo o Instituto de Pesquisas Tecnológicas (IPT, 1994), certas regiões são mais atingidas pelas erosões urbanas devido à litologia, às características do solo e também ao 
regime das precipitações. Exemplos clássicos de áreas degradadas por erosões urbanas, em regiões sedimentares da bacia do rio Paraná, são encontrados nas cidades de Assis, Bauru e Marília. IPT (op. cit.) estima que existam no Estado de São Paulo em torno de 3.000 erosões, sendo que cerca de 40 estão localizadas no município de Bauru.

\subsection{1 - Gênese e evolução}

Futai (2002) cita que a gênese do processo pode ocorrer pela evolução da erosão superficial e, quando há processos subsuperficiais, a causa não está esclarecida. Sobre a evolução, o autor explica que a influência do fluxo subsuperficial é maior quando o lençol freático é atingido, induzindo a erosão pelo aumento do gradiente hidráulico.

A gênese dos processos erosivos em Bauru geralmente ocorre pela ocupação urbana, iniciada pelo desmatamento e redução da infiltração, reforçada pela pavimentação de ruas (aumento do escoamento superficial) de traçado incorreto, sem rede de drenagem pluvial e aumento da concentração de água de chuva em córregos e rios. Além desses fatores, Cavaguti (1995) cita a ausência de estruturas de dissipação de energia nos pontos de descarga, que causam a concentração do efeito. O autor também explica que depois de atingir o lençol freático o processo intensificasse e torna-se complexo, ocorrendo fenômenos de piping, descalçamentos e escorregamentos do talude, que resultam na evolução das vertentes. Nessa fase são facilmente observáveis erosão à montante (recuo das cabeceiras) e surgimento de novos ramos. A maioria dos locais erodidos se localiza no terço inferior da encosta, com a ocupação ocorrendo de montante para a jusante.

Vilar (1987) ressalta que, embora intuitivamente, costume-se associar maior quantidade de chuva com maior erosão, isto nem sempre ocorre, sob qualquer condição. As regiões de maior precipitação no globo terrestre, geralmente estão recobertas por maior vegetação, como nas regiões tropicais úmidas. Além disso, a relação entre carência de vegetação e erosão não é linear. Em regiões parcialmente cobertas por vegetação, nota- 
se que a erosão não cresce proporcionalmente com a área desprotegida. Entretanto, observa-se um crescimento grande da erosão, quando a área desprotegida começa a ser maior do que $30 \%$ da área total.

Rodrigues (1982) complementa que é importante avaliar não só a quantidade, mas também a intensidade e duração dos eventos. Almeida Filho \& Ribeiro (1995) analisaram a correlação de índices pluviométricos com a ocorrência de fenômenos erosivos e observaram que, na região de Bauru, ocorrem chuvas tipicamente tropicais, como temporais violentos intensos e de curta duração. Elas são concentradas no período da primavera e verão e normalmente escassas nos demais, podendo ocorrer nos períodos secos de inverno.

Segundo Camapum de Carvalho (2005), é através da análise das causas e de estudos geológico-geotécnicos que se obtém o correto diagnóstico dos mecanismos de eclosão e evolução das erosões, como o indicado na Figura 6. Mortari (1994) afirma que o mecanismo de evolução das erosões lineares está associado às características geológicogeotécnicas e estruturais da região e, além disso, que inicialmente o processo erosivo tem a forma de $\mathrm{V}$, podendo ser modificado ou não ao atingir camadas menos intemperizadas.
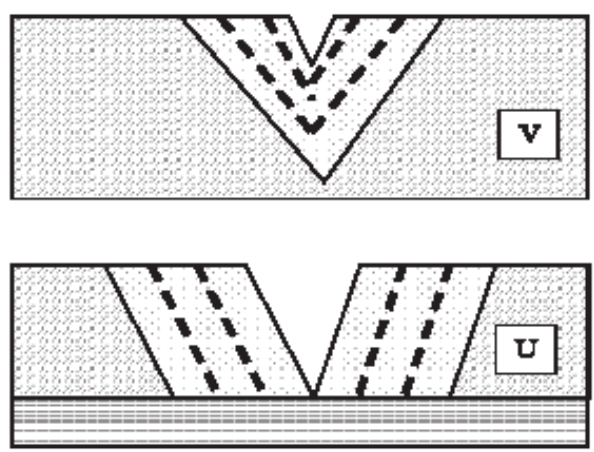

Figura 6. Representação esquemática de modelo evolutivo de erosão em $\vee$ e U (Camapum de Carvalho, 2005)

Futai et al. (2005) analisaram a evolução de uma voçoroca e constataram que o processo se dá devido aos escorregamentos. Através de análises numéricas, os autores observaram que o mecanismo de erosão ocorre da seguinte forma: o solo está permanentemente na condição saturada; o escorregamento forma círculos superficiais, 
sendo parte do solo carreado pelo escoamento superficial e a parte remanescente no pé do talude é solapada pela saída da água. Ao secar, o talude volta a estabilizar, porém novos escorregamentos podem ocorrer com devido à ocorrência de novas chuvas.

Segundo Cavaguti (1994), ocorrem no perímetro urbano diversas ravinas e voçorocas de grande porte, desencadeadas pela concentração do escoamento de águas superficial propiciada pela ocupação. Boa parte das erosões é formada em cabeceiras de drenagem que sofreram processo de reativação intensa, através da combinação de ações de águas de superfície e de subsuperfície. As características do solo, aliadas a falta de um planejamento urbano, colaboram para que Bauru possua vários pontos de erosão.

Um dos principais obstáculos ao crescimento da cidade de Bauru é o problema de subdimensionamento da drenagem. Com a grande quantidade de erosões na cidade, o problema torna-se cada vez maior e, além disso, o município é adepto a prática de aterrar suas erosões com entulho gerando uma série de danos ambientais pela falta de critérios técnicos e fiscalização, conforme cita Cavaguti (op. cit.).

Os estudos realizados em diversas áreas erodidas no Brasil indicam que a evolução de erosões decorre dos seguintes aspectos: ocupação de encostas a partir da baixada sem a devida infra-estrutura de drenagem, urbanização ultrapassando espigões atingindo vertentes não ocupadas e núcleos habitacionais com infra-estrutura deficiente ou de loteamentos projetados de maneira inadequada feita sem critérios técnicos que levassem em consideração os impactos ambientais na área urbana.

\subsection{2 - Investigação de áreas erodidas ou susceptíveis à erosão}

Mortari (1994) afirma que o mecanismo de evolução das erosões está associado às características geológico-geotécnicas e estruturais (porosidade, arranjo dos grãos e estrutura reliquiar) da região afetada. Daí a necessidade da investigação geotécnica, pois estas características atuam como controladores da grande maioria os processos atuais. 


\section{Caracterização}

Os ensaios de caracterização são utilizados para determinar a porosidade, distribuição granulométrica, porcentagem de fração argilosa (que pode causar problemas como a expansão do solo), índice de plasticidade, entre outros, pois são fatores que influem na capacidade do solo resistir ou não a erosão. Para essa finalidade podem ser citados os ensaios de granulometria conjunta, limites de consistência e massa específica dos solos. Sua larga utilização se deve ao fato da fácil execução e interpretação dos resultados, além de custos relativamente baixos.

\section{Erodibilidade}

A erodibilidade indica o grau de facilidade com que as partículas de solo destacamse e são transportadas. Esse é um dos fatores que contribuem para a erosão do solo principalmente pela ação da água. São poucos os métodos de análise da erodibilidade. Nessa pesquisa, serão empregadas as metodologias propostas por Inderbitzen (desenvolvido em 1961), Nogami \& Villibor (1979) com o ensaio de absorção de água, Alcântara \& Vilar (1998) com o ensaio de penetração de cone modificado.

O ensaio de Inderbitzen é o mais antigo utilizado na determinação da erodibilidade do solo. Seu procedimento básico consiste em fixar um anel cilíndrico contendo uma amostra de solo em uma rampa de inclinação variável (Figura 7). O escoamento de água na rampa provoca erosão no solo, que pode ser avaliada através da massa das partículas do solo removidas pela água.

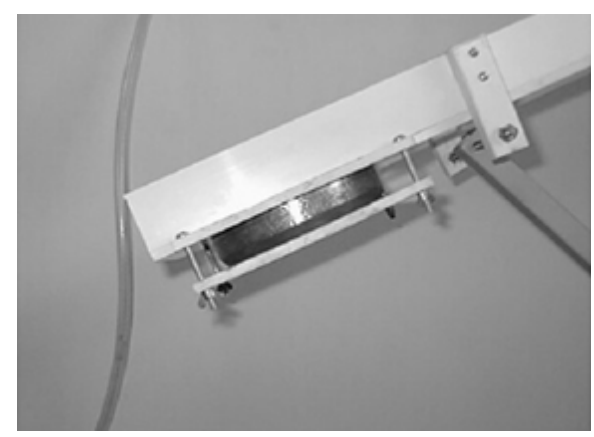

Figura 7. Detalhe da rampa do ensaio Inderbitzen com o anel fixado (Fragassi \& Marques, 2001) 
Santos \& Merschmann (2001) destacam as limitações de aplicabilidade do ensaio Inderbitzen, verificadas através de análises de resultados, e a necessidade de considerar o impacto das gotas de chuva no solo, representando locais com pouca vegetação ou desprovidos dela.

Nesse contexto, Freire (2001) sugeriu a simulação do impacto da gota de chuva no solo, para isso, o fluxo de água foi lançado em forma de gota diretamente sobre o corpode-prova (Figura 8). Através dos resultados, observou que houve um aumento considerável nos valores de perda de massa, considerando a desagregação do solo por impacto da chuva, fato esse que modifica a classificação do solo em relação ao seu potencial erosivo de baixa erodibilidade a alta erodibilidade. O autor também constatou através de resultados de ensaios de cisalhamento direto que a erodibilidade não é dependente dos parâmetros de resistência.

Sobre o mesmo ensaio, Mendes (2006) explica que, após o início da saturação, há um instante que a capacidade de arraste do escoamento supera a resistência das agregações, pois há sua saturação progressiva, diminuindo a resistência da mesma e carreando-as. Na avaliação da erosão superficial no município de Bom Jardim-RJ, verificou o destacamento e o carreamento de pequenos agregados de partículas durante o ensaio, em intervalos de tempo variáveis, ocasionando aparente estabilização em determinado instante e, retomada do aumento de perda de solo em seguida. Ele explica que o fato ocorre porque o escoamento satura progressivamente as agregações das partículas, diminuindo a resistência das mesmas. Assim, em determinado instante após o início da saturação, a capacidade de arraste do escoamento supera a resistência das agregações carreando-as. 


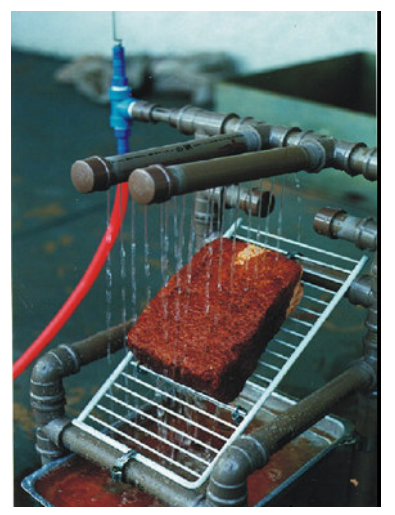

Figura 8. Sistema com simulação do impacto da gota de chuva (Freire, 2001)

Bastos (1999) sugere que os solos mais erodíveis apresentam taxa de erodibilidade superiores a $0,1 \mathrm{~g} / \mathrm{cm}^{2} / \mathrm{min}$ e que os solos mais resistentes à erosão apresentam valores inferiores a $0,001 \mathrm{~g} / \mathrm{cm}^{2} / \mathrm{min}$. Para concluir, Inderbitzen (1961) cita que esse ensaio indica somente o quão rápido um solo irá erodir sob condições diferentes de compactação, inclinação e vazão. Também explica que os resultados devem ser considerados de forma qualitativa, pois o ensaio não é preciso.

O método de Nogami \& Villibor (1979) baseia-se nos resultados de ensaios de absorção d'água e perda de massa por imersão em corpos de prova. Para avaliar a erodibilidade do solo é utilizado o índice de erodibilidade que depende do índice de absorção e da perda de massa seca. Nesse ensaio, anota-se o volume de água absorvido pelo corpo de prova em função do tempo por cerca de 1 hora. Após, realiza-se o ensaio de perda por imersão (Pi) por um período de 24 horas. Os corpos-de-prova são moldados a partir de amostras indeformadas com dimensões de $53 \mathrm{~mm}$ de diâmetro e 50mm de altura. 0 índice de absorção (S) é o coeficiente angular do trecho inicial retilíneo.

Nogami \& Villibor (1979) propõem um limite no qual E=52S/P, amostras acima dessa relação são classificadas como de alta erodibilidade (Figura 9). Porém, Pejon (1992) realizou pesquisas e sugeriu o limite de 40S/P. É importante ressaltar que tais limites foram definidos a partir de ensaios em amostras de taludes rodoviários erodidos. 


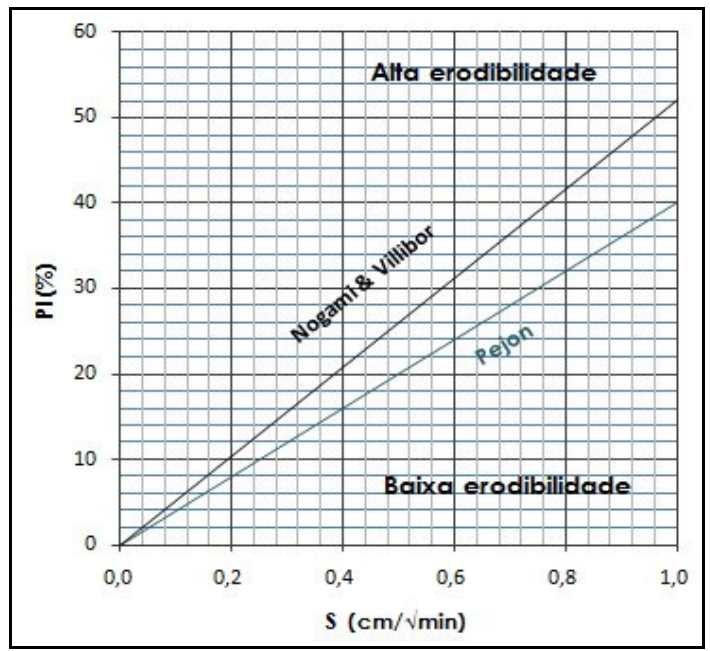

Figura 9. Gráfico para avaliação da erodibilidade do solo segundo proposta de Nogami \&Villibor (1979)

O método de penetração de cone (Figura 10), desenvolvido para avaliar erosões, baseia-se na determinação da variação de penetração (DP), que relaciona a penetração natural (Pnat) e a penetração após a saturação por uma hora (Psat), e da variação limite (DPlimite) indicada por Alcântara \& Vilar (1998). Para valores de DP maiores que DPlimite, a erodibilidade é alta; caso contrário, ela é baixa, como pode ser observado na Figura 11.

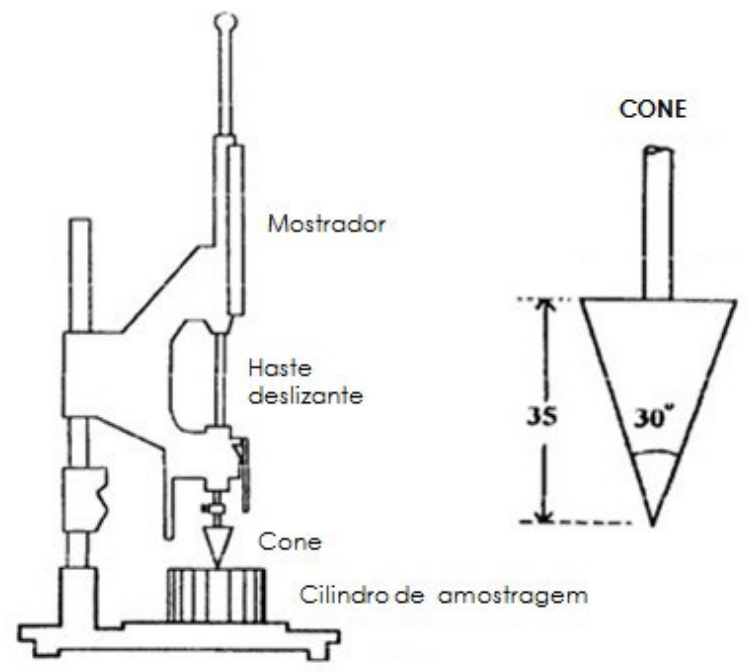

Figura 10. Equipamento do ensaio de penetração de cone (Alcântara \& Vilar, 1998) 


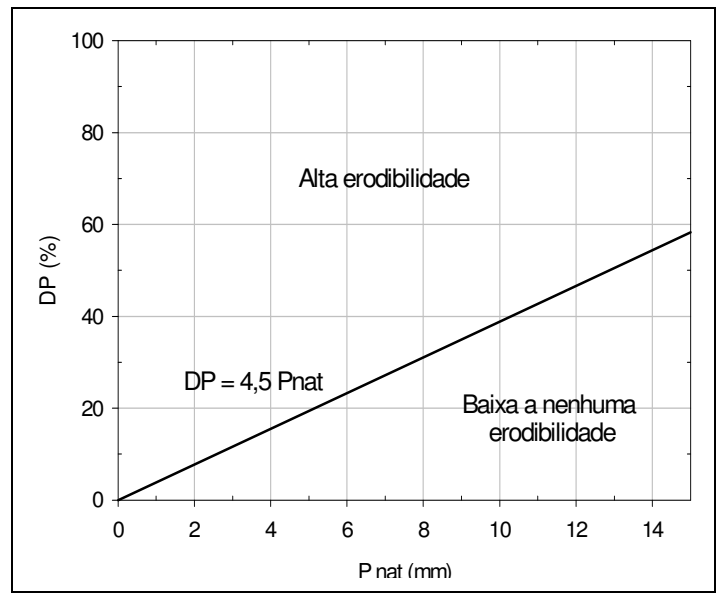

Figura 11. Gráfico para avaliação da erodibilidade do solo sugerido por Alcântara \& Vilar (1998)

Dessa forma, é possível classificar os solos em dois níveis de erodibilidade:

- Baixa a nenhuma - Aparência estável sem ocorrência de sulcos ou ravinamento em toda a face do talude. Presença de sulcos lineares subparalelos de pequena profundidade (aproximadamente $10 \mathrm{~cm}$ ). O efeito erosivo do escoamento d'água sobre a face do talude pode ser observado na sua base.

- Alta - Intensa remoção do solo, gerando cavidades de dimensões variadas e grandes sulcos. Presença de ravinas localizadas com forma similar aos sulcos, mas com profundidades que geralmente alcançam mais de um metro. Possibilidade de ocorrência de deslizamento das camadas sobrejacentes.

\section{Perfilagem estratigráfica}

Como o perfil das camadas de material inconsolidado pode variar com o local, pois podem sofrer diferentes graus de alteração, é importante determinar o perfil estratigráfico do local erodido, bem como as propriedades dos solos envolvidos, e assim conhecer a camada que pode ser responsável pelo desencadeamento do processo.

Para definição do perfil estratigráfico podem ser realizados ensaios de campo como a sondagem de simples reconhecimento com medida de SPT, ensaios de piezocone (CPTU) ou ensaios de dilatômetro plano (DMT). 
Lima et al. (2001) utilizaram sondagens de simples reconhecimento e ensaios de caracterização (granulometria conjunta) para mostrar que as propriedades do solo variam em conseqüência do fluxo de água nos taludes de uma voçoroca. Com os resultados, verificaram que o percentual de argila diminui com a profundidade, enquanto ocorre uma tendência ao aumento da fração mais arenosa. No solo argiloso estudado, os autores observaram que enquanto há um aumento da fração arenosa próximo a borda da voçoroca, ocorre uma diminuição da fração argilosa, mantendo os maiores percentuais nos perfis de solo das sondagens mais afastadas da erosão.

Outro trabalho que cita a utilização de sondagem de simples reconhecimento é o de Lafayette et al. (2005), que verificou diferente graus de alteração e oxidação do ferro ao longo de um perfil longitudinal ao processo erosivo. Dessa maneira, pode concluir que a areia superficial presente ocorre devido a uma formação existente no local e encontra-se sobreposta a uma camada de argila, originada do solo residual de granito. Também avaliaram a erodibilidade de sulcos e ravinas através de ensaios de caracterização, de permeabilidade in situ (Permeâmetro Guelph), de cisalhamento, de adensamento e de erodibilidade (metodologia MCT e Inderbitzen), além da realização de sondagens de simples reconhecimento.

Relacionando pedologia e geotecnia, Futai (2002) justifica a necessidade de análise de perfis simples devido às mudanças de propriedades com a profundidade, que ocorrem com o grau de alteração do material. Além disso, pode-se identificar a variação mineralógica do perfil, que depende da rocha matriz, evolução pedológica e grau de intemperismo ocorrido.

A sondagem de simples reconhecimento com medida do SPT é um método mais difundido de investigação, pois permite a caracterização das camadas a partir de ensaios com as amostras coletadas durante o ensaio e atinge grandes profundidades.

Em locais onde o processo está evoluído, pode-se observar o perfil do solo nos próprios taludes da erosão, permitindo a identificação da camada responsável sem a necessidade de sondagens. A observação do perfil nos taludes também permite a 
avaliação da estabilidade, auxiliando o estudo de como se dá o processo de evolução do processo erosivo, como o tipo de escorregamento, existência de caminhos preferenciais do fluxo de água. Isso também pode ser definido a partir de algumas sondagens de simples reconhecimento realizadas em pontos estratégicos da área de estudo. Além disso, o ensaio permite a definição da posição do nível d'água no terreno.

O ensaio de penetração de cone (CPT) e de piezocone (CPTU), que possuem uma larga aplicação no campo de investigação geotécnica e geoambiental, tem se mostrado uma ferramenta importante na definição do perfil estratigráfico e estimativa de parâmetros geomecânicos através das diversas correlações, de grande importância para o processo erosivo, tais como:, ângulo de atrito interno, coesão e condutividade hidráulica. O ensaio de penetração do cone consiste basicamente em se cravar uma ponteira cônica no terreno com velocidade padronizada. O equipamento elétrico possui as mesmas características do cone mecânico, porém é constituído por uma única peça, que possui células-de-carga instrumentadas eletricamente, permitindo a medida da resistência de ponta (qc) e do atrito lateral (fs) diretamente na ponteira. Através de $q_{c}$ e fs, calcula-se a razão de atrito, Rf (=fs/qc), parâmetro esse utilizado para a identificação e classificação de solos. No piezocone, além de se medir qc e fs, é possível medir também a poro-pressão gerada durante a cravação (U), bem como registrar sua dissipação quando se para a cravação.

Apesar dos ábacos de classificação de solos para interpretação de ensaios CPT/CPTU, bem como as correlações para estimativa dos parâmetros geomecânicos terem sido desenvolvidas para solos sedimentares de regiões temperadas e ainda não terem sido adequadamente adaptadas para solos tropicais, é possível utilizar essa ferramenta de investigação para caracterização de perfis de intemperismo, conforme demonstrado por De Mio (2005). A vantagem desse ensaio é o detalhamento do perfil do terreno com rapidez, ao mesmo tempo que se estima parâmetros geomecânicos de interesse para provisão de comportamento de obras geotécnicas.

Outros trabalhos também mostram a importância da investigação geotécnica no estudo de processos erosivos. Vilar (1987) menciona os ensaios de natureza física, como: 
granulometria, plasticidade, peso específico dos sólidos, umidade equivalente; além daqueles de auxiliem na determinação da densidade, agregabilidade, permeabilidade e taxas de infiltração, umidade, expansão e profundidade dos horizontes de solo para avaliar a erodibilidade. Em especial, ressaltou os ensaios Inderbitzen (1961) e Nogami \& Villibor (1979).

Agena \& Saad (1995) fizeram um estudo da erodibilidade para a prevenção dos efeitos erosivos e admitem três parâmetros de quantificação: relação de dispersão, relação de erosão e relação granulométrica. Os autores realizaram ensaios de análise granulometria e mineralógica, condutividade hidráulica saturada e densidade do solo e umidade.

Salomão \& Queiroz Neto (1995) efetuaram análises granulométricas, de troca de bases e das porosidades no solo de Bauru para planejamento de uso do solo. Também foram executados testes de infiltração, curvas de retenção e piezometria na determinação da dinâmica e funcionamento hídrico.

Corghi \& Giacheti (2005) estudaram um processo erosivo em Bauru-SP e realizaram ensaios de granulometria conjunta e penetração de cone para avaliar a erodibilidade do solo local. Já Futai et al. (2005) estudaram a evolução de uma voçoroca com ensaios de caracterização, químicos, mineralógicos, dispersão por submersão (erodibilidade), desagregação com saturação por capilaridade, adensamento, cisalhamento direto, triaxiais e permeabilidade.

\subsection{3 - Alguns estudos prévios sobre erosão}

Segundo Vilar (1987), a erosão constitui um processo natural no desenvolvimento da paisagem terrestre. A atuação lenta e contínua dos processos erosivos traduz-se por modificações normalmente perceptíveis após longos períodos de tempo. A interferência do homem altera esse processo natural, diminuindo, ou como é mais comum, aumentando sua intensidade. Parte das partículas erodidas pode continuar agregada mesmo com a ação do fluxo de água, característica do processo erosivo. O autor explica que contribuem para 
a agregação das partículas, além da argila, a matéria orgânica, os cátions divalentes adsorvidos e os fenômenos de cimentação.

Em eventos de precipitação sucessivos é comum notar que no primeiro evento a erosão é maior e tende a decrescer nos eventos subseqüentes. Essa variação tem sido creditada à retirada de finos pelos agentes de transporte, de forma a haver uma menor quantidade de partículas disponíveis para transporte em eventos sucessivos. Da mesma forma, o escoamento superficial ao saturar-se de sedimento ou ao ter a capacidade de transporte reduzida também deposita partículas. A redução na capacidade de transporte geralmente ocorre por redução de declividade, como nas porções terminais da encosta, ou pela presença de obstáculos que alteram o fluxo, como a vegetação (Vilar, op. cit.).

Além disso, Vilar (op. cit.) cita que algumas explicações plausíveis para o escoamento de chuvas superiores à capacidade de infiltração são: a formação de uma crosta superficial e a existência de áreas parciais de contribuição. Tem-se observado que a gota de chuva, além de destacar partículas de solo, também compacta alguns tipos de solos, formando crostas, mais resistentes e menos permeáveis. Em conjunto com a ação mecânica da gota, podem ocorrer também diversos processos químicos, que se traduzem por uma cimentação superficial, como a silificação de materiais inconsolidados arenosos. A erodibilidade dos materiais componentes de taludes possui peculiaridades devido ao fato de que os taludes de corte englobam solos de características diversas. Normalmente, costuma-se encontrar uma camada superficial que sofreu processos de laterização e, subjacente a essas camadas, surgem formações sedimentares e/ou solos de alteração (saprolitos).

A erosão dos taludes em solos tropicais, diferentemente dos processos clássicos de erosão pela chuva, caracteriza-se pelo fato de que nem sempre é possível distinguir se as partículas erodidas o foram pela chuva ou se já estavam destacadas do maciço por processos de desagregação superficial. O segundo fator refere-se ao fato de que as superfícies de solos laterizados, uma vez expostas, comumente vêem-se protegidas por uma película superficial que melhora a sua resistência à erosão. No entanto, a interferência da 
secagem-umedecimento não é simples de se quantificar, além de provocar nos solos lateríticos a deposição de uma camada superficial cimentante de sílica, trazida do interior do maciço pela água que percola e que posteriormente é evaporada. Há uma distinção de comportamento entre os solos de natureza laterítica e saprolítica, sendo que os primeiros tendem a apresentar superfícies estáveis frente aos processos de desagregação e erosão (Ferreira et al., 1993).

Rodrigues (1982) estudou processos erosivos acelerados do centro-leste do estado de São Paulo através de ensaios de campo e laboratório, como: caracterização, permeabilidade, adensamento, compactação, compressão triaxial e Inderbitzen. A partir dos resultados, concluiu que os sedimentos das voçorocas apresentam baixos valores de compacidade, de ângulo de atrito e de coesão e que os dois últimos podem sofrer redução com a percolação de água. Além disso, o autor observou que os sedimentos arenosos de granulação fina são os que apresentam maior susceptibilidade à erosão e o arraste das partículas pelo lençol freático, bem como a liquefação do solo do pé do talude, são os principais eventos para a evolução lateral das voçorocas. Já sobre a ciclagem do solo, observou que ela contribui para o desenvolvimento de trincas paralelas aos taludes e que essas contribuem para a evolução do processo lateral e longitudinalmente. Nogami \& Villibor (1995) consideram o efeito da molhagem e secagem sucessivas e a ação da gravidade, efeitos que influenciam consideravelmente a erosão, podendo ser o motivo principal da mesma.

Em sua pesquisa, Queiroz (1986) notou que as porções convexas de escavações de taludes rodoviários freqüentemente apresentam instabilidades e uma das razões pode ser a diferença nas condições de tensões induzidas nos taludes convexos e côncavos. Hoek (1972, apud Queiroz, 1986) explicou que em um talude côncavo, a forma arqueada tende a induzir tensões laterais de compressão, que aumentam a tensão normal através de planos de ruptura potencial e, portanto, aumentam a resistência de atrito destes planos face ao escorregamento. Por outro lado, a relaxação das tensões laterais, no caso de taludes convexos, dá origem a uma redução na tensão normal, através de planos de ruptura 
potencial e, em casos extremos, podem ocorrer aberturas de sistemas de juntas verticais em condições semelhantes àquelas de tensões laterais de tração.

Futai (2002) explica que índices que representam a plasticidade e a granulometria não são suficientes para caracterizar o comportamento de solos erodíveis. Muitas vezes o solo está na condição não-saturada, que associada à estrutura e às propriedades mineralógicas, pode apresentar problemas de engenharia, como colapso ou expansão, quando inundados. Por isso, sugere que a classificação quanto à colapsibilidade do solo deveria considerar também o estado de tensões e parâmetros de estado do solo, que pode ser representado pelo índice de vazios e o grau de saturação. Em complemento, Cintra (2004) explica que na condição não inundada, a curva carga versus recalque é variável em função da sucção matricial, permanecendo como condição crítica a inundada (sucção praticamente nula). Devido a isso, pode-se concluir que a avaliação do colapso do solo pode variar com o tempo, logo o solo pode ser classificado como colapsível e não colapsível com a variação da sucção matricial.

Futai (op. cit.) também ressalta a necessidade de classificação específica para solos tropicais, pois esses apresentam comportamento e propriedades não avaliadas pelas classificações tradicionais. O autor reuniu informações obtidas por vários trabalhos, além de realizar ensaios de adensamento, cisalhamento direto, triaxiais com controle de sucção e simulações através dos softwares SEEP e UNSAT2 para estudo de um processo erosivo.

Futai et al. (2005) observaram que o processo de voçorocamento é causado por escorregamentos rasos causados pela diminuição da sucção, porém não há saturação do talude, pois ocorre saída de água pelo pé da voçoroca. Segundo os autores, os resultados mostraram que há uma concentração de tensões cisalhantes devido à diminuição da sucção ao longo do talude, que contribuem para o escorregamento e mudança da geometria do mesmo. O talude volta a estabilizar depois de seco, porém novas chuvas podem desestabilizá-lo novamente.

Ferreira \& Pejon (2007) verificaram que a instalação e propagação das voçorocas dependem das características do meio físico, sendo os fatores mais importantes do 
desencadeamento o índice pluviométrico, a erodibilidade dos materiais geológicos presentes e a forma do relevo, associado ao uso e ocupação do solo. No local estudado, apesar da infiltração elevada, concluíram que as chuvas podem produzir escoamento superficial, agindo como deflagrador ou intensificador dos processos. Por fim, destacam a importância da evolução dos processos erosivos em áreas urbanas como ferramenta útil no planejamento territorial, alcançando uma gestão ambiental mais equilibrada.

Nos climas frios e temperados, há um elevado grau de saturação das camadas de solos, por isso a infiltrabilidade é pouco considerada em estudos geotécnicos tradicionais. Porém, nos climas tropicais úmidos, esse fenômeno é freqüente. Nogami \& Villibor (1995) explicam que, caso a infiltrabilidade for maior que a precipitação pluviométrica, a erosão não ocorrerá.

Segundo Camapum de Carvalho (2005), o intemperismo químico associado à lixiviação e à laterização, além de alterar a química e a mineralogia do perfil do solo, proporciona grandes alterações estruturais, fazendo com que o efeito das tensões iniciais e/ou da rocha na sua estrutura seja removido. Além disso, complementa que os solos tropicais tipificam o processo erosivo, ficando a profundidade da erosão condicionada à espessura do manto de intemperismo e sua largura à geologia. Além disso, a agregação e cimentação dos solos intemperizados interferem na inclinação dos taludes, fazendo com que eles sejam bastante íngremes.

\section{3- Solos não-saturados}

Há uma enorme variedade de situações em que os solos se comportam de modo diferente aos das premissas clássicas da Mecânica dos Solos. As complexidades dos solos não-saturados são muito grandes, pois a interação sólidos-água-ar e suas interfaces traz enormes dificuldades, tanto analíticas quanto de controle durante os ensaios. Nesse sentido, a técnica de translação de eixos e o desenvolvimento de pedras porosas de alto valor de 
entrada de ar em muito contribuíram com os ensaios, nos quais se busca o controle da sucção para previsão do comportamento dos solos (Vilar et al., 1995).

O escoamento em meio poroso não-saturado difere do saturado na natureza da força determinante do movimento e na condutividade hidráulica. Em um solo não-saturado, a água está sob a condição de uma pressão subatmosférica, ou sucção, cujo gradiente de potencial pode ser considerado como uma força tratora. Outra diferença importante é que a condutividade deixa de ser máxima, passando a depender do teor de água contido no meio poroso (Popi, 1982).

Vilar et al. (1995) ressalta que prevalece a opinião de que a sucção matricial governa o comportamento mecânico e hidráulico do solo. No caso de baixas sucções, pode-se empregar o ensaio de funil de pedra porosa, cujo princípio de funcionamento é bem definido em Libardi (1995). Outro ensaio útil é o de papel filtro, no qual a sucção é obtida através da medida de umidade de equilíbrio do papel em conjunto com o solo. Necessita da garantia de contato entre o papel e o solo e de curvas de calibração do papel filtro para determinar o valor de sucção. Outro fato influente nos resultados é a estanqueidade do conjunto papel-solo, que pode influenciar na pesagem do papel, principalmente em balanças de alta precisão necessárias nesse tipo de ensaio.

A curva de retenção de água nos solos tem sido muito utilizada no estudo de solos não saturados, uma vez que é a única forma de relacionar a sucção com um índice físico do solo, A Figura 12 mostra as principais curvas de retenção para diferentes tipos de solos.

A curva com distribuição de poros bimodal possui dois pontos de inflexão, isto é, duas pressões de entrada de ar. Essa distribuição é caracterizada pelos macroporos, formados pelos vazios entre agregados e/ou grãos maiores, e pelos microporos, formados no interior dos agregados. A forma da curva depende da trajetória do ensaio, que basicamente são três: de drenagem, de umedecimento e mista. A diferença entre trajetórias é provocada pelo fenômeno da histerese (Rodrigues, 2007). 


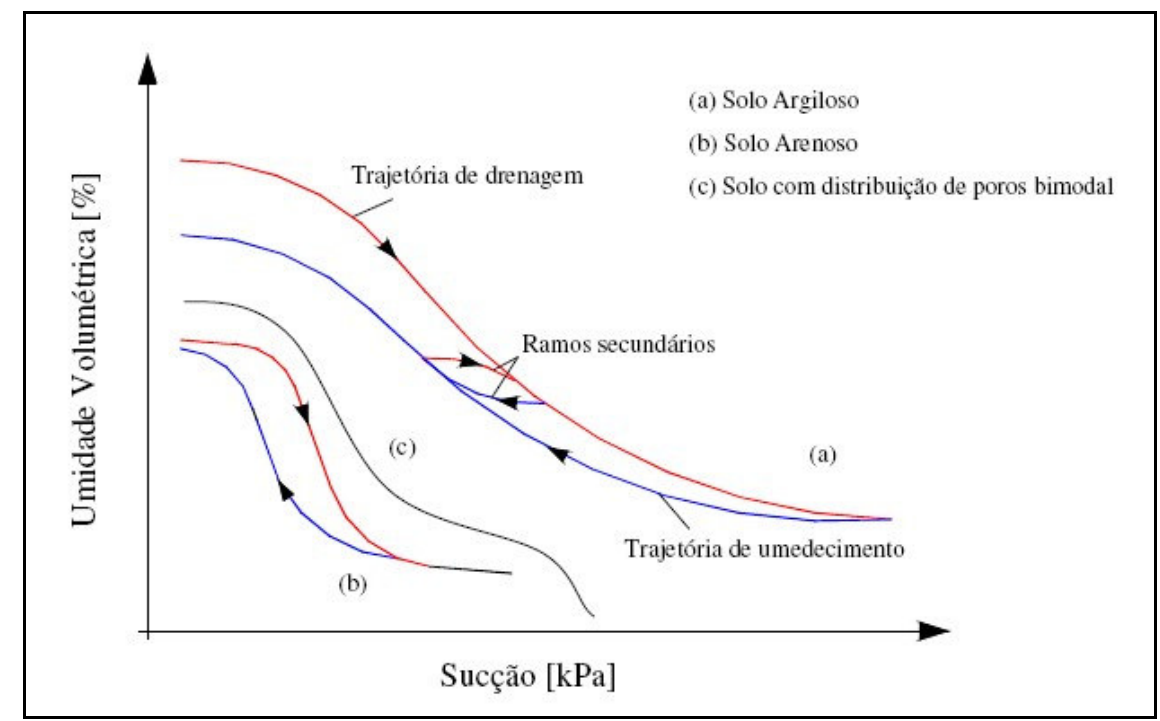

Figura 12. Principais curvas de retenção de água para diferentes tipos de solos (Rodrigues, 2007)

Futai (2002) explica que as deformações induzidas ao solo modificam sua curva característica, pois alteram a quantidade, tamanho e distribuição dos vazios. Dessa forma, a estrutura do solo é que determina a forma da curva. Assim como Futai (op. cit.) será considerado que o comportamento dos solos não-saturados é governado pela sucção matricial.

Lima (2003) estudou a atuação dinâmica da água na estabilidade de encostas e destaca que um dos mecanismos de ruptura é causado pela rápida redução da sucção matricial devido à infiltração nas encostas e ao avanço da frente de saturação, que pode provocar uma perda de coesão aparente. Logo, segundo o autor, é muito importante estudar a variação temporal da resistência do solo e sua porcentagem relativa de ar e água na análise de processos erosivos, pois o comportamento mecânico do solo é afetado fundamentalmente pela variação do efeito da sucção devido às mudanças na umidade. Dessa forma, analisou que no fluxo de água em meio saturado o produto lixiviado é carregado para fora do maciço e, no fluxo em meio não saturado, ocorre uma tendência desse produto se depositar e acumular a partir da face dos taludes, devido a fatores como aumento da concentração e perda de umidade. 


\section{3 - A CIDADE DE BAURU}

O município de Bauru está localizado no centro do Estado de São Paulo. O relevo regional é formado em sua maioria (65\%) por colinas amplas e suaves, com solos residuais de arenitos das Formações Marília, Adamantina, do Grupo Bauru, e Cenozóicas, com textura de areia fina pouco argilosa (Ferreira et al., 1993).

As erosões lineares são um problema recorrente local causado pela ocupação humana. Cavaguti (1994) estudou erosões lineares na cidade e explica que, com o crescimento da cidade sem o planejamento adequado, as áreas erodidas centrais eram recuperadas, enquanto surgiam outras áreas degradadas na periferia. O pior caso de evolução observado em Bauru ocorreu em 1993, ano em que a chuva foi o principal agente causador e colocou em risco obras de engenharia, edificações e a população em várias partes da cidade. Além disso, grande impacto ambiental ocorreu nos locais de deposição do material carreado (várzeas e fundos de vales). Os prejuízos econômicos e à qualidade de vida fizeram necessário decretar estado de calamidade pública nesse mesmo ano.

Duas bacias hidrográficas dividem o município, sendo os principais rios o Batalha e o Bauru. Na segunda, encontra-se a maior parte da área urbana e, logo, as áreas mais afetadas pela ocupação.

A seguir, encontra-se a Figura 13, na qual estão presentes os principais processos geodinâmicos do estado de São Paulo e as áreas em que são dominantes, segundo o Instituto de Pesquisas Tecnológicas (IPT). Observa-se nessa figura, que a cidade de Bauru (ponto vermelho) encontra-se numa área com predominância de erosão, fato esse de acordo com o histórico local. 


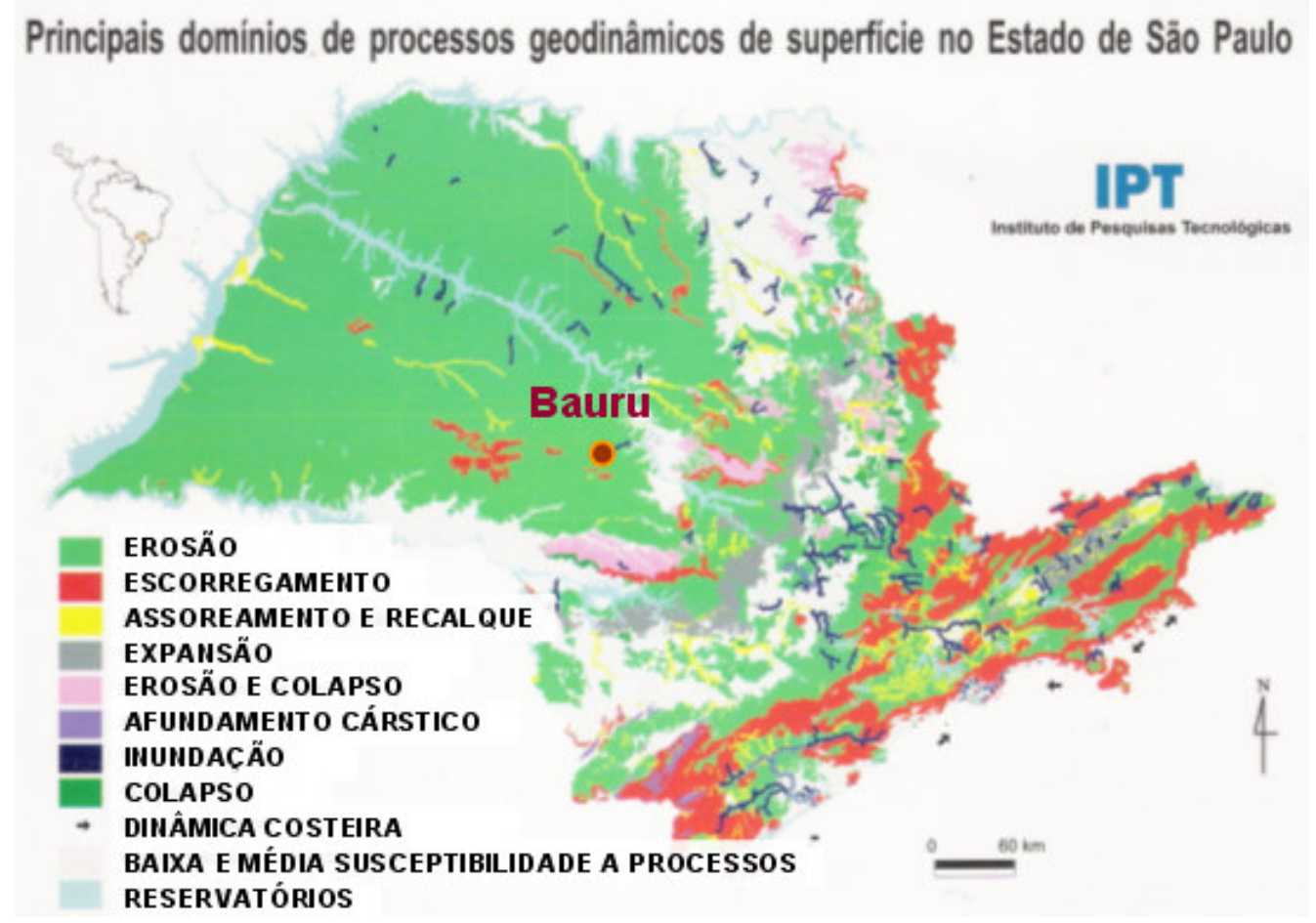

Figura 13. Principais áreas de processos geodinâmicos em São Paulo (IPT)

\section{1 - Aspectos gerais}

Almeida Filho (2000) explica que a distribuição de chuvas no Estado de São Paulo está associada ao domínio das massas tropicais (continentais e marítimas) e polares, com correntes de sul e leste; à disposição do relevo e à proximidade ou não do mar. Também cita que o clima de Bauru é tropical de altitude (CWA), ocorrendo temporais violentos com pancadas intensas e de pouca duração. Normalmente, eles ocorrem no final da tarde, devido ao forte aquecimento diurno, e se concentram nos período primavera-verão.

O clima da região, no qual ocorre alternância de estações chuvosas e de relativamente secas, faz com que haja uma intensa lixiviação dos finos do horizonte superficial, formando um solo com uma estrutura porosa e permeável, normalmente com o nível freático profundo. Em geral, além de apresentar elevada erodibilidade os solos também são colapsíveis. As temperaturas são altas e relativamente estáveis no ano todo. Já as precipitações, apresentam grande variabilidade, sendo por isso de grande interesse 
nesse tipo de clima. As precipitações máxima e mínima ocorrem em janeiro e julho, respectivamente. Verifica-se também que as temperaturas máximas normalmente ocorrem em janeiro, enquanto as mínimas são verificadas no mês de julho, bem como suas médias. A vegetação dominante atual é do tipo cerrado.

A chuva é o principal fator do clima e afeta diretamente os processos erosivos. Assim, episódios torrenciais localizados são potencializadores da erosão acelerada e, como ocorrem aleatoriamente, de difícil previsão.

Em relação à ação da chuva devem ser consideradas a quantidade e a duração do fenômeno, pois chuvas de pouca intensidade contínuas podem erodir maior quantidade de solo do que uma torrencial de pouca duração. Várias pesquisas tentaram determinar o limite de intensidade a partir do qual a erosão inicia-se, porém não se obteve um valor final pela diversidade de fatores influentes.

\section{2 - Geologia local}

Segundo Ferreira et al. (1993), os sedimentos do grupo Bauru ocupam no estado de São Paulo quase todo o Planalto Ocidental onde predominantemente se assentam sobre os basaltos da Formação Serra Geral. Sugere que a seqüência estratigráfica é a que subdivide o grupo nas Formações Caiuá, Santo Anastácio, Adamantina, Marília e Itaqueri. Dentre essas, as presentes na cidade são: Adamantina e Marília.

Segundo IPT (1981, apud Queiroz, 1986), a Formação Adamantina (Grupo Bauru) ocorre por vasta extensão do oeste do estado de São Paulo, constituindo os terrenos da maior parte do Planalto Ocidental, só deixando de aparecer nas porções mais rebaixadas dos vales dos principais rios, onde já foi removida pela erosão.

Conforme De Mio (2005) a Formação Adamantina está presente nos vales e porções mais baixas do terreno e é superior estratigraficamente. É constituída por depósitos fluviais com presença de arenitos finos e muito finos, podendo localmente apresentar cimentações e nódulos carbonáticos, lentes de siltitos arenosos e argilitos em bancos maciços com 
estratificação cruzada de pequeno e médio porte. A porção superficial desses sedimentos foi submetida a intenso intemperismo tropical, podendo estar presente colúvio, apesar da inexistência de linha de seixos na interface. As fácies de deposição sugerem extenso sistema fluvial meandrante e, na parte inferior dessa formação, a drenagem era pouco organizada e o ambiente de deposição de menor energia, com predominância de lagos rasos. Predominam rochas sedimentares posteriormente submetidas a processos de morfogênese e pedogênese. Desta forma, o perfil deve refletir características de rochas sedimentares, as transformações destes materiais pelos processos e coberturas por solos coluvionais polifásicos. Em suas interpretações do perfil, verificou que os solos apresentam complexa geometria das diferentes zonas devido à somatória de processo a relacionados à gênese de sedimentos e às modificações devido à pedogênese tropical.

O contato superior da Formação Adamantina é transicional com a Formação Marília, na qual os sedimentos ocorrem no reverso da cuesta arenito-basáltica, formando espigões entre rios e em áreas isoladas com indicações de maior compartimentação tectônica que a formação anterior. Eles encontram-se visivelmente erodidos, o que dificulta a reconstituição da paleografia original e são formados por arenitos grosseiros a conglomeráticos, mal selecionados, pobre em matriz e estruturas sedimentares. Camadas de lamitos, com intensa bioturbação, separam os bancos de arenito e, em certas áreas, há a presença de forte cimentação carbonática podendo a matriz representar até $40 \%$ da rocha. Sua característica mais notável é a presença de abundantes nódulos carbonáticos, que causam intensa concentração de óxidos de cálcio, contribuindo para a fertilidade dos solos nessas áreas. Porém, a carbonatação desses arenitos não é homogênea e no interior da unidade existem bolsões sem a presença desse cimento, o que causa grandes problemas em obras civis com intenso desmoronamento. Os espigões apresentam intenso coluvionamento em seus flancos devido à erosão. A união dos corpos coluvionares ao sopé das escarpas gera uma cobertura arenosa solta de alta erodibilidade e conseqüente voçorocamento (Ferreira et al., 1993). 
O sedimento cenozóico é produto do retrabalhamento dos materiais do Grupo Bauru e das Formações Serra Geral e Botucatu através de pequeno transporte em meio aquoso e depositado na forma de coluviões e aluviões, ocupando assim grande parte do estado. Devido à sua gênese, apresenta-se pouco compacto, com partículas razoavelmente selecionadas, o que the garante uma estrutura muito porosa. São freqüentemente separados da camada subjacente por uma linha de seixos e a espessura é geralmente inferior a 10 metros e acima do nível d'água. A textura do solo pode ser arenosa ou argilosa, dependendo do material de origem, com as cores vermelho e marrom variando de claro a escuro. A ação do intemperismo, aliada às condições climáticas tropicais, causou o processo de laterização, ou seja, quando compactado, adquire propriedades mecânicas e hidráulicas favoráveis à sua utilização em obras.

A maior parte do estado é coberta por dois tipos de solos: os latossolos e os podzólicos, descritos por Queiroz (1986).

latossolos: são solos espessos, homogêneos, com perfis de alteração de dezenas de metros, porosos, com aspecto maciço, porém friável quando seco, apresentam grande capacidade de infiltração da água superficial devido ao grande volume e dimensão dos poros, são típicos de áreas planas, colinas suaves e de topos de morrotes com declividade entre 1 e $10 \%$. As texturas dependem da rocha mãe: argilosos se provenientes do basalto e arenosos se, dos arenitos. Os latossolos de textura-média, de cor amarelo-avermelhada predominam em mais de $50 \%$ do Oeste do Estado de São Paulo, caracterizam-se pela estabilidade natural e baixa tendência aos problemas geotécnicos, desde que não expostos a condições intensas de uso, quando podem desenvolver graves processos de degradação. Os principais problemas advêm do uso inadequado provocado pela concentração de água em grandes volumes, gerando sulcos na superfície do solo, que rapidamente podem evoluir para ravinas, atingir o lençol freático e se tornar boçorocas de grande porte e de difícil controle. A saturação quando atingida em sua totalidade desestrutura o solo, provocando colapso e abatimento no terreno. 
podzólicos: são solos profundos, bem desenvolvidos, heterogêneos, e com clara divisão em camadas, característica que os diferencia dos latossolos. Na paisagem, aparecem em áreas de colinas de média a alta declividade (6 a $20 \%$ ), onde os processos erosivos são mais intensos. Em geral, são mais frágeis que os latossolos, revelando médio a alto potencial de desenvolvimento de processos erosivos, tão logo é retirada a cobertura vegetal. Em conjunto, latossolos e podzólicos recobrem mais de $70 \%$ do estado de São Paulo. O perfil de um terreno podzólico do oeste paulista apresenta um horizonte superficial (A) arenoso que passa abruptamente para um horizonte subsuperficial (B) argiloso e deste para um horizonte profundo (C) argilo-silto-arenoso.

Em geral, os solos podzólicos são mais susceptíveis à erosão que os latossolos e ocorrem usualmente em topografia mais movimentada. Também apresentam logo abaixo do horizonte superficial uma camada com maior concentração de argilas, que formam uma barreira à infiltração das águas e, conseqüentemente, o fluxo de água logo abaixo da superfície e paralelo à encosta tende a propiciar maior erosão nesse solo.

Agena \& Saad (1995) definiram classes de susceptibilidade potencial dos solos de Bauru à erosão. A primeira encontra-se no sistema latossolo areno-argiloso/ solos hidromórficos arenosos de sopé de vertente dos sistemas de relevos de colinas amplas e intermediárias, com baixas declividades $(<6 \%)$, apresentam macroporosidade e condutividade hidráulica elevadas com drenagem vertical livre, com índice de incidência de ravinas menor que 30 e de voçorocas menor que 15, com ocorrência de ravinas, sobretudo em cabeceiras de nascente e raras voçorocas provocadas pelo mau uso do solo. Correspondem à classe de baixa susceptibilidade à erosão. As classes 2 e 3 são encontradas no sistema latossolo areno-argiloso/ solos com o horizonte B textural/ solos hidromórficos de sopé de vertente em sistemas de relevo de colinas médias e declividades mais elevadas. Os horizontes B texturais apresentam baixa macroporosidade e condutividade hidráulica e dificuldade de drenagem vertical, acarretando circulação lateral importante no limite dos horizontes A e B. O lençol freático é concentrado em piping, com surgências ao nível do afloramento de rocha das encostas. A sensibilidade à erosão é pequena nos latossolos do 
topo (declividades $<6 \%$, como na primeira classe), média a forte nos perfis B de meia encosta, declividade de 6 a 12\%, com ravinamento generalizado e grande susceptibilidade no terço inferior, declividade entre $12 \%$ e $20 \%$, onde ocorrem ravinas e voçorocas. O sistema afloramento de rocha/ Litossolo/ Brunizem/ solo com B textural nas vertentes e sopés dos morrotes e escarpas, com declividades elevadas engloba outras duas classes. A drenagem vertical é impedida no limite solo/substrato rochoso, com drenagem lateral importante. Os índices de incidência de ravinas e voçorocas são altos (superiores a 50), indicando grande susceptibilidade à erosão com ravinas e voçorocas generalizadas. E a última classe, que possui a maior susceptibilidade, corresponde aos fundos de vale sujeitos á inundação e assoreamento.

\section{3 - Características geotécnicas do solo}

Conforme Carta Geotécnica elaborada pelo IPT (1994), a cidade possui como processo predominante a erosão por sulcos, ravinas e voçorocas com grau de susceptibilidade de alta, induzida principalmente por concentração do escoamento superficial, a muito alta. As classes de susceptibilidade estão mais bem detalhadas nos subitens a seguir, conforme IPT (1994).

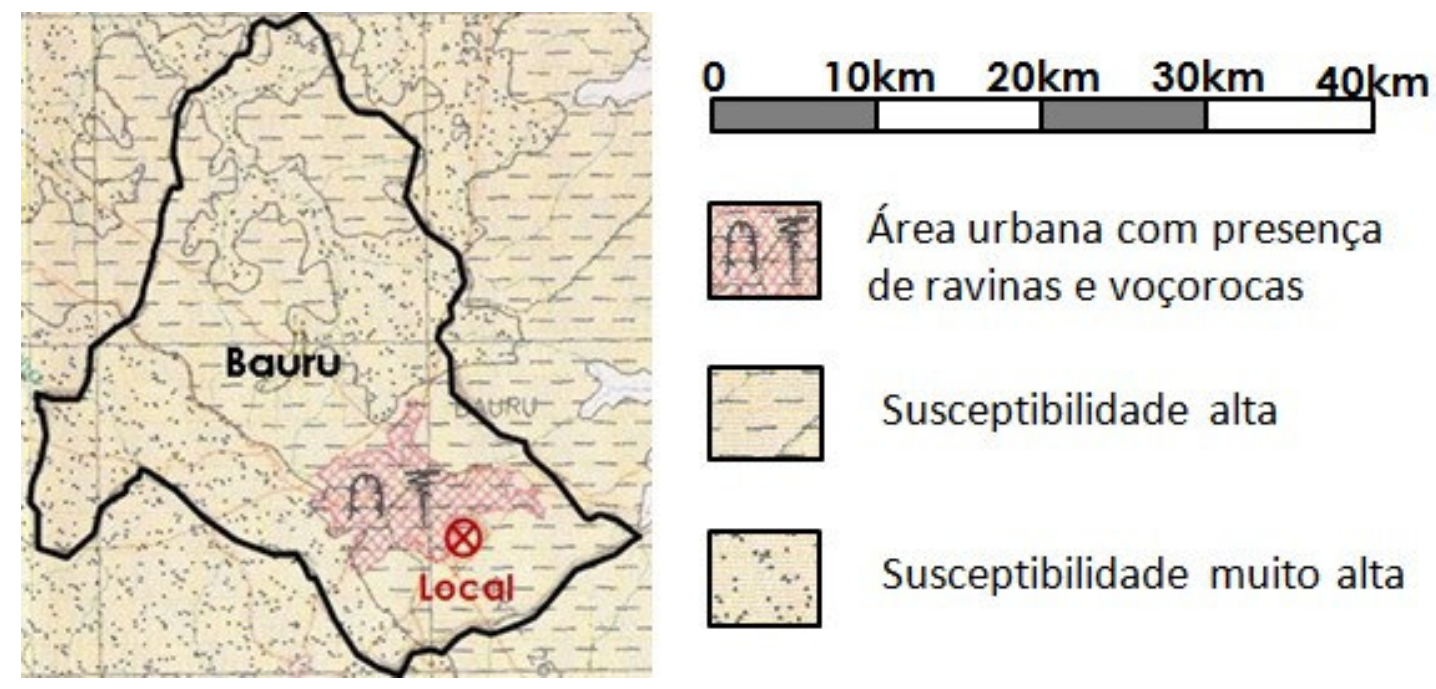

Figura 14. Zonas de susceptibilidade à erosão em Bauru (IPT, 1994) 


\subsection{1 - Susceptibilidade muito alta}

\section{Tipologia e descrição}

Sulcos e ravinas desenvolvidos a partir do simples desmatamento em cabeceiras de drenagem e de matas ciliares; da concentração do escoamento das águas superficiais em loteamentos e obras viárias sem as medidas de proteção adequadas e do manejo agrícola não conservacionista.

Voçorocas se desenvolvem a partir dos sulcos e ravinas, quando interceptam o nível d'água ou diretamente de surgências de água, por reativação de cabeceiras, através do piping. Estas voçorocas são, em geral, ramificadas e de dimensões médias (profundidades médias em torno de 10 metros).

Assoreamento intenso nos cursos e corpos d'água, principalmente nos de menor porte, gerados pelo aporte de sedimentos provocado pelas erosões.

\section{Aspectos físicos de interesse}

Substratos constituídos pelos arenitos das formações Adamantina, Marília, Botucatu, Pirambóia e Itaqueri. Relevo predominantemente de colinas médias e morrotes com declividades entre $10 \%$ e $20 \%$. Ruptura de declive na encosta. Solo podzólico vermelhoamarelo com textura areno-argilosa ou arenosa média, transição nítida ou abrúptica entre horizontes A e B, gradiência textural A/B, horizonte A com estrutura porosa e B com estrutura prismática, drenagem truncada.

Escoamento superficial e subsuperficial importantes, com forte gradiente hidráulico e nível d'água em torno de 5 metros, com ocorrência de N.A. suspenso, além de surgências na encosta. 


\section{Aspectos do uso do solo}

Abrange, em maior parte, áreas de pastagens / campo antrópico, vindo em segundo plano as áreas de cultivo. Quanto à ocupação urbana, predominam as cidades de pequeno e médio porte.

\section{Recomendações para uso do solo}

Proteger cabeceiras de drenagem e fundos de vale mantendo ou recuperando a vegetação arbórea. Adotar cuidados especiais de drenagem e proteção superficial nas obras com extensa movimentação de terra, além de desenhos de parcelamento que evitem a concentração demasiada do escoamento superficial em ruas no sentido da pendente da encosta. Instalar sistemas adequados de drenagem das águas superficiais, concomitantemente à abertura das vias ou outras obras que apliquem concentração de escoamento. Tomar cuidados especiais relativos à dissipação de energia em todo e qualquer ponto de lançamento de águas superficiais.

Recuperar as voçorocas que coloquem em risco moradias e obras de infra-estrutura, com realização de estudos geológico-geotécnicos de detalhe nos projetos de recuperação e coibir o lançamento de lixo nas mesmas.

\section{Observações complementares}

Esta unidade recobre quase $25 \%$ do estado e concentra a ocorrência de $80 \%$ das erosões. É a porção mais crítica, que engloba as regiões de Presidente Prudente, Marília, Bauru, São José do Rio Preto e Franca.

\subsection{2 - Susceptibilidade alta}

\section{Tipologia e descrição}

Sulcos e ravinas desenvolvem-se somente a partir do escoamento concentrado das águas pluviais associado ao uso do solo (urbano, viário, etc.). Voçorocas de grande porte 
formam-se pelo aprofundamento de ravinas e interceptação do nível d'água, alargando-se e ramificando-se através de piping e descalçamento dos taludes. Apesar de serem menos freqüentes que na unidade anterior, atingem dimensões muito maiores, principalmente em profundidade, conseqüência da espessura dos solos e da localização profunda do nível d'água.

O lançamento concentrado nas encostas, de águas superficiais provenientes de loteamentos, de estradas, ferrovias e obras civis é a causa principal destes processos. Nas chuvas intensas, a velocidade de progressão das voçorocas pode atingir centenas de metros por dia, significando até risco de vida à população.

Verifica-se o assoreamento intenso dos cursos e corpos d'água, principalmente os de menor porte, em conseqüência da erosão por sulcos, ravinas e voçorocas.

\section{Aspectos físicos de interesse}

Arenitos da Formação Adamantina, Marília, Botucatu, Pirambóia, Itararé e das formações Cenozóicas (Itaqueri, Rio Claro e outros).

Relevo predominantemente de colinas amplas com declividades entre 0 e 10\%. 0 solo predominante é o latossolo vermelho-amarelo e amarelo com textura média a arenosa, são homogêneos e espessos, estrutura maciça e porosa, microagregado, drenagem livre. 0 nível d'água é profundo, normalmente encontrado a mais de 10 metros.

\section{Aspectos do uso do solo}

Corresponde em maior parte às áreas de cultivos, seguidas das áreas de pastagens / campo antrópico. Abrange cidades de maior porte em franco processo de expansão urbana.

\section{$\underline{\text { Recomendações para uso do solo }}$}

Adotar desenhos de parcelamento que evitem a concentração demasiada do escoamento superficial em ruas no sentido da pendente da encosta. 
Instalar sistemas adequados de drenagem das águas superficiais, concomitantemente à abertura das vias ou outras obras que impliquem concentração do escoamento. Além de cuidados especiais relativos à dissipação de energia em todo e qualquer ponto de lançamento das águas superficiais.

Recuperar as voçorocas que coloquem em risco moradias e obras de infra-estrutura, aliadas a estudos geológico-geotécnicos de detalhe nos projetos de recuperação. Coibir o lançamento de lixo nas voçorocas.

\section{Observações complementares}

Esta unidade contém as maiores voçorocas do Estado de São Paulo e ocorre em grande parte do oeste do estado, cobrindo quase $40 \%$ de sua área.

\section{4 - Local de estudo}

Conforme o índice de concentração de erosão de Almeida Filho (2000), a sub-bacia do Rio Bauru é a mais crítica entre as existentes na cidade, apesar da predominância das declividades suaves, pois áreas com declividades de $6 \%-12 \%$ e $12 \%-20 \%$ são as que apresentam maior quantidade de processos erosivos na cidade. Os processos se desenvolvem nessa sub-bacia em função das modificações causadas pelo parcelamento do solo, a implantação de sistema viário e a grande mobilização de serviços de terraplenagem.

O processo erosivo estudado (Figura 15 e Figura 16) localiza-se ao longo do Córrego da Água Comprida, afluente do Rio Bauru, em uma região cercada por loteamentos residenciais. 


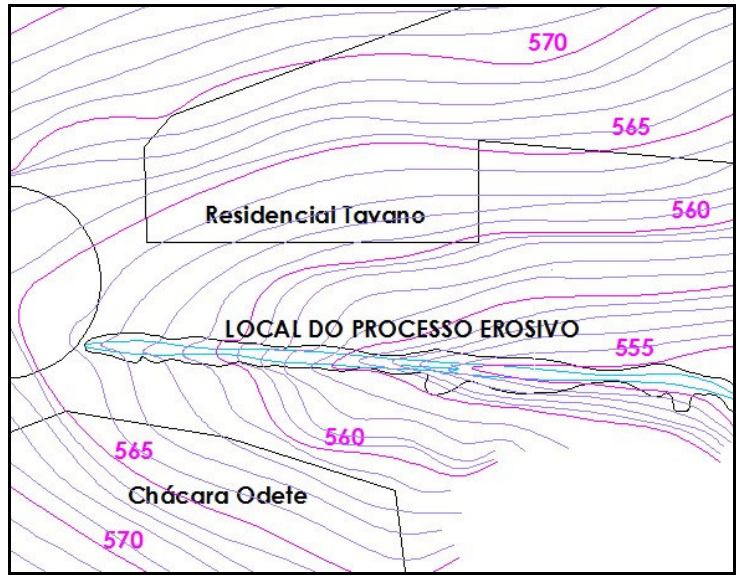

Figura 15. Local de estudo

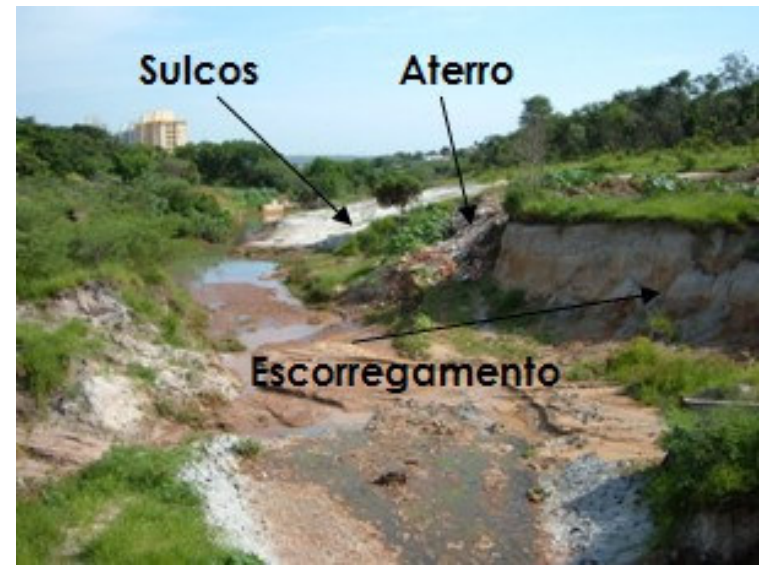

Figura 16. Vista geral do trecho erodido

Optou-se por esse local, pois apesar das várias restrições ambientais exigidas pelos órgãos públicos para evitar problemas ambientais, principalmente para a instalação do residencial Chácara Odete, ele apresentou problemas erosivos nas áreas de preservação permanente.

A área compreendida margeia o fundo de vale do córrego da Água Comprida, região Sudeste da cidade, entre as rodovias SP-255 e SP-300. O contingente de água à montante da microbacia do córrego desemboca em galerias subdimensionadas, desencadeando um processo constante de reparos na área.

Observa-se que o agravamento das erosões existentes não se justificou apenas pelos resultados das análises geológico-geotécnicas, mas, sobretudo pela displicência constatada com as questões de drenagem, principalmente no que diz respeito ao descumprimento de prazos e procedimentos estabelecidos em projetos aprovados pelos órgãos públicos (Corghi, 2005).

A origem da erosão do Jardim Colonial remete ao carreamento de seu sistema de dissipação de águas pluviais devido ao mau dimensionamento e à falta de manutenção. O processo erosivo aumentou devido à falta de rigor técnico ao se lidar com reparos de danos ambientais, enquanto proprietários e secretarias públicas ausentavam-se da responsabilidade sobre o ocorrido. Por fim, a erosão cresceu vertiginosamente desde que se vem acompanhando o processo, que data do segundo semestre de 2003 (Figura 17). 
A erosão na área verde foi licenciada para servir de bolsão de entulho (Figura 18), como medida emergencial no segundo semestre de 2003 e o depósito de sedimentos era procurado pela maioria dos caçambeiros, devido à boa localização da área. Porém, como a preocupação era a de se estabilizar o crescimento da erosão, o interesse era de que o material tivesse sido corretamente depositado e compactado no fundo da erosão, o que não foi rigorosamente seguido.

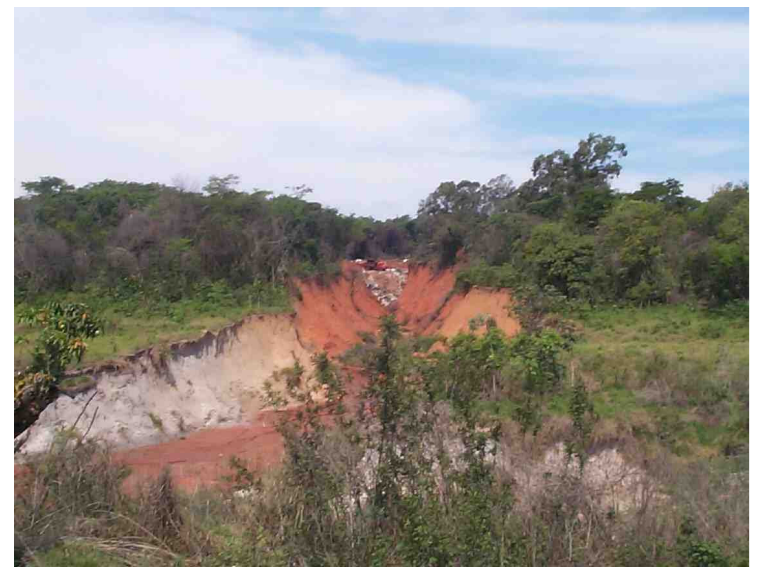

Figura 17. Ramificação da erosão em 2003 (Corghi, 2005)

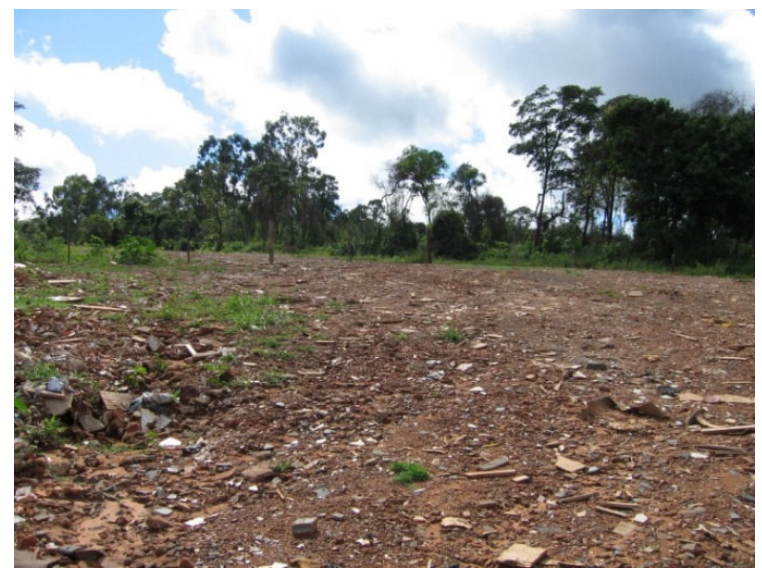

Figura 18. Ramificação fechada com entulho e lixo orgânico em 2006

Apesar do devido licenciamento da erosão para servir de bolsão de entulho, lixo orgânico foi jogado em seu interior, devido à pouca fiscalização no local. A instalação de outro loteamento próximo desse residencial, não coincidentemente, colabora para que mais matéria orgânica, principalmente galhos de árvores, seja jogada no interior do bolsão de entulho.

Esses locais de deposição de resíduos de construção civil e lixo residencial orgânico, aliados às quebras de tubulações de esgoto, degradam a área erodida e criam maiores problemas ambientais e sanitários.

Cavaguti \& Hamada (2007) citam que, nas boçorocas-lixões, há a formação de trincas e desnivelamentos da superfície em virtude do recalque causado pela redução de volume do lixo por decomposição. As trincas favorecem a infiltração da água de escoamento superficial, o que favorece a retomada do processo erosivo. Tal retomada 
ocorre em maior intensidade, pois o lixo apresenta alta permeabilidade e de menor resistência à erosão, resultando assim em boçorocas de dimensões maiores que as originais e no deslocamento do lixo depositado à jusante. Caso o processo não volte a ocorrer, a área é considerada inadequada para construção, devido aos recalques citados acima. Além disso, o local fica contaminado pelo chorume exudado e pelo lixo, resultando em problemas no solo e nas águas, ressaltando o lençol freático.

O Residencial Chácara Odete sofreu com a demora para implantação dos dissipadores de energia previstos ao final das tubulações dos sistemas de drenagem, o que acabou por agravar consideravelmente o processo erosivo, que constava de uma pequena ravina antes da instalação do empreendimento. A conseqüência da forma de implantação e o atraso no cumprimento dos prazos legais culminaram na queda de taludes e no agravamento do processo de assoreamento do córrego, chegando inclusive a alterar sensivelmente o seu percurso natural.

Um estudo de macrodrenagem aprovado pela Prefeitura foi utilizado visando a contenção do processo, com ênfase à correção das obras já instaladas e atingidas pelas chuvas.

\section{Gênese e evolução do processo erosivo}

Almeida Filho (2000) associou eventos pluviosos com diagnóstico de erosões em Bauru e concluiu que episódios de chuvas fortes podem intensificar a ocorrência de processos erosivos e, conseqüentemente, das inundações.

Conforme a análise das características do solo, se pode concluir que já havia propensão à ocorrência de processos erosivos. Entretanto, com a construção de loteamentos, houve um grande aumento da relação entre forças solicitantes e resistência dos sistemas naturais. O processo tornou-se visível com a implantação de loteamentos em áreas de alta susceptibilidade à erosão, associada ao mau dimensionamento e à ausência de obras de infra-estrutura. Sem as medidas de controle de erosão, a área foi rapidamente degradada. Em relação aos landforms, verifica-se que o processo ocorre na cabeceira e ao longo do fundo de vale da área analisada. Já as ramificações ocorrem nas encostas. 
A evolução se deu através da falta de estrutura dos sistemas de drenagem e do mau dimensionamento das mesmas, associados às chuvas de grande intensidade, características do local. Com a evolução do processo, sistemas de dissipação de energia foram atingidos e destruídos, colaborando com o avanço e aumentando a erosão na ramificação do processo principal.

Tal ramificação, devido suas grandes dimensões, foi aterrada principalmente com entulho de construção e coberta com uma camada de solo. Uma vez que o local não foi revegetado após o aterro, o solo da superfície foi removido por erosão laminar. Apesar disso, atualmente, encontra-se no local a presença de grama e mato, que contribuem com a resistência superficial do solo, verificando o não ressurgimento do processo erosivo local. A Figura 19 a Figura 24 mostram o histórico da evolução do processo erosivo no local estudado.

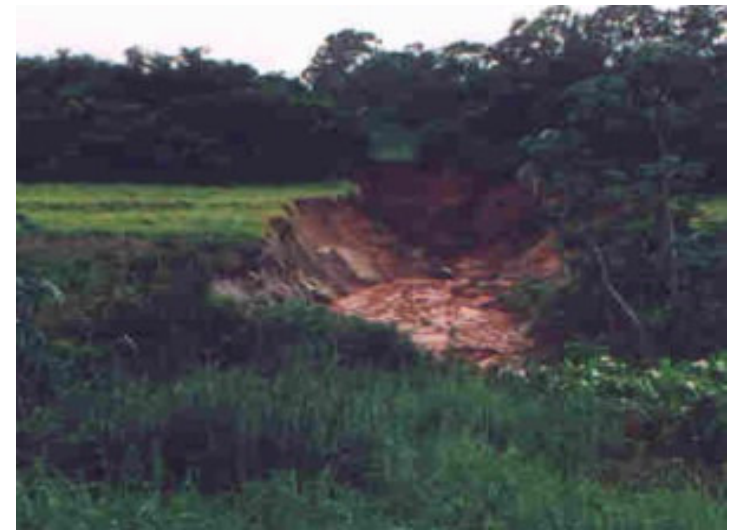

Figura 19. Ramificação em 2002 (Corghi, 2005)

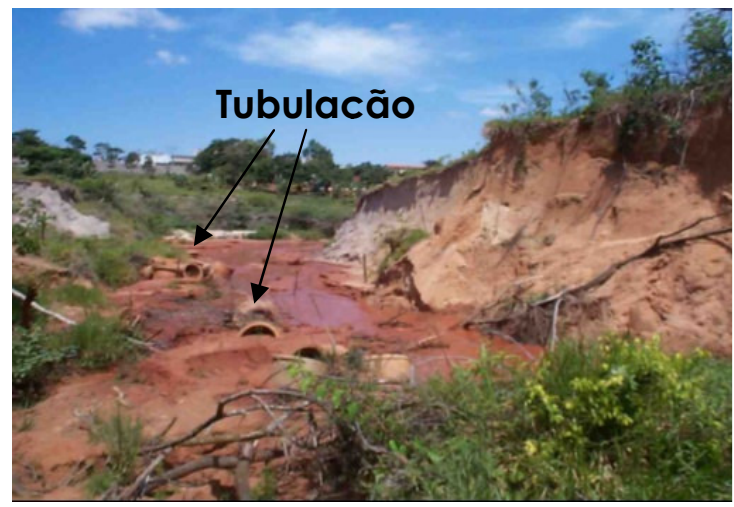

Figura 21. Destruição das galerias em 2004 (Corghi, 2005)

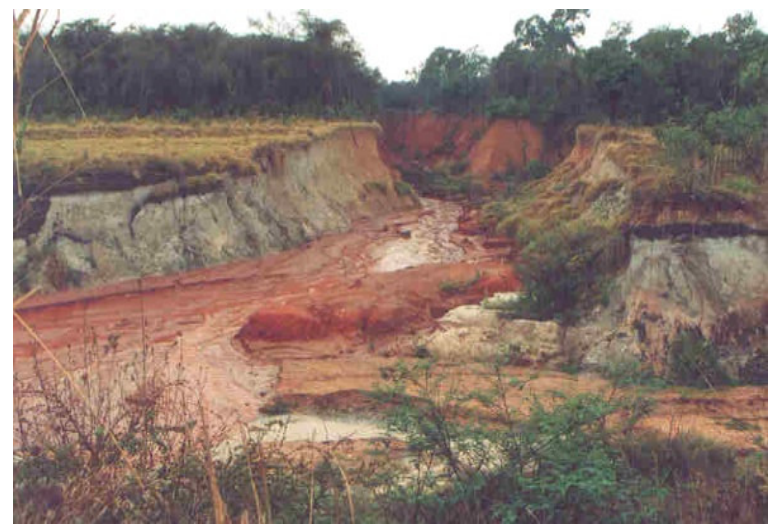

Figura 20. Avanço em 2003 (Corghi, 2005)

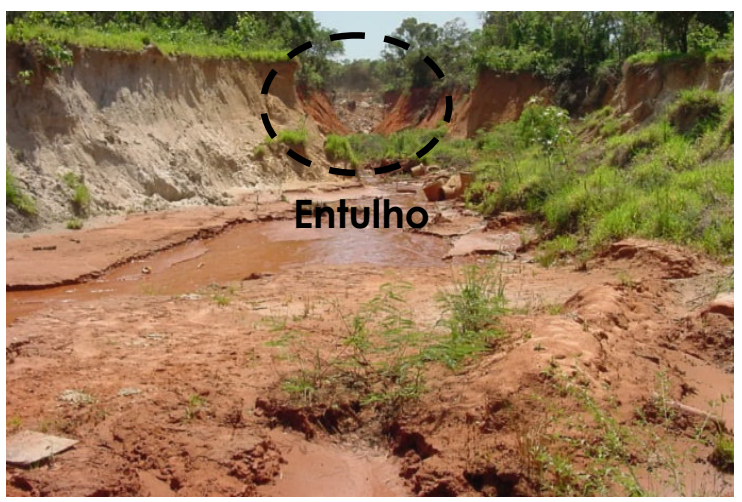

Figura 22. Início do aterramento em 2004 (Corghi, 2005) 


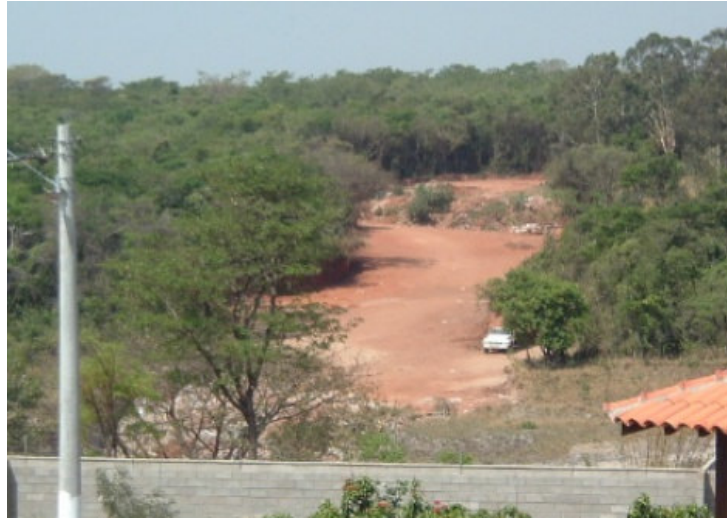

Figura 23. Ramificação aterrada e coberta com camada de solo em 2005 (Corghi \& Giacheti, 2005)

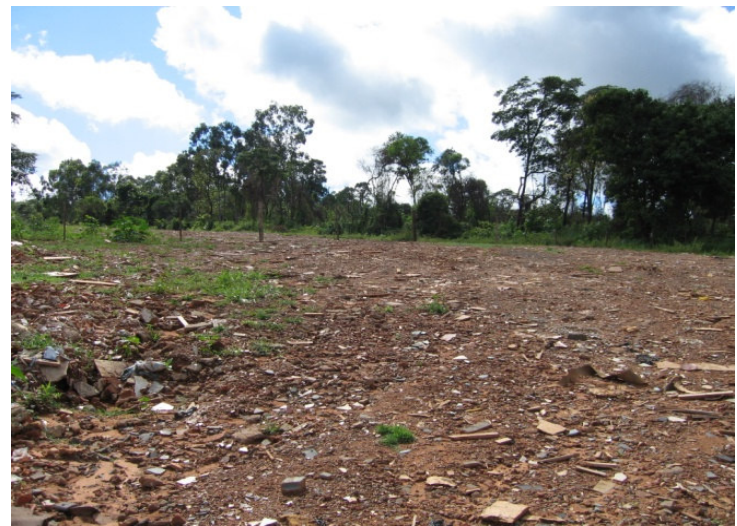

Figura 24. Remoção da camada superficial de solo da região aterrada em 2006

A ausência de sistemas de dissipação de energia ao final das tubulações de água associado ao período de concentração de chuvas durante o verão colaborou com a evolução do processo erosivo e assoreamento ao longo do córrego. Medidas paliativas foram utilizadas no controle do processo erosivo principal, porém não suportaram a ação da água da chuva, como pode ser observado na Figura 25.

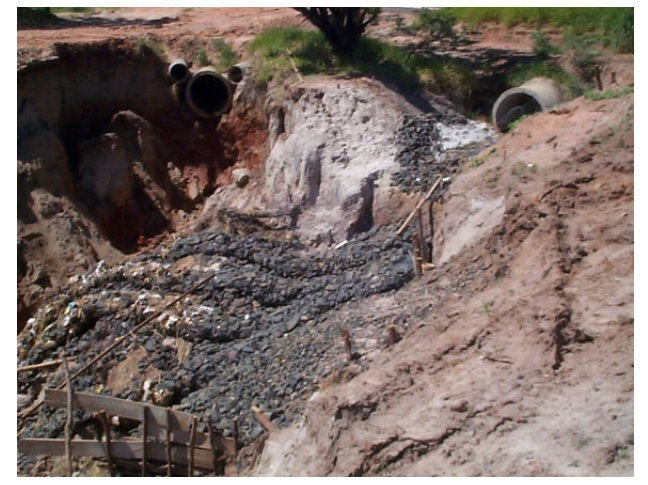

Figura 25. Gabião destruído pela ação da água em 2003 (Corghi \& Giacheti, 2005)

Um dos fatores responsáveis foi o fato das medidas corretivas não levarem em conta as feições do terreno, fato esse verificado pela execução de aterros somente para preencher as ramificações existentes e, ao longo do córrego, foram feitos taludes laterais de pequena inclinação até o nível do terreno, a fim de garantir a estabilidade. Além disso, 
observa-se que na maioria dos locais afetados não houve preocupação com a influência das águas subsuperficiais, levando a ocorrência de novos escorregamentos.

Devido à rápida evolução da erosão, foi feito um projeto de retificação do leito do córrego, com a combinação da canalização aberta e cachimbos. Entretanto, a falta de manutenção está contribuindo com a reinstabilização dos taludes de contenção. A evolução do processo de instalação de obra e os problemas observados no local estão ilustrados na Figura 26 a Figura 31.

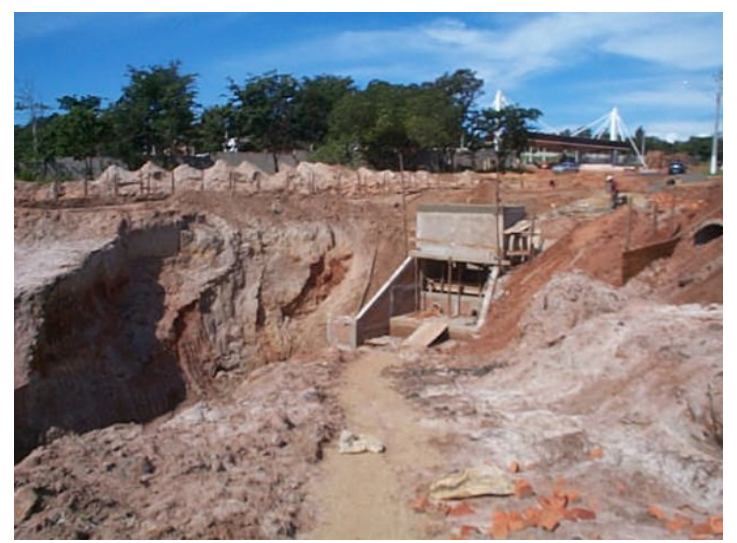

Figura 26. Início das obras em 2004 (Corghi \& Giacheti, 2005)

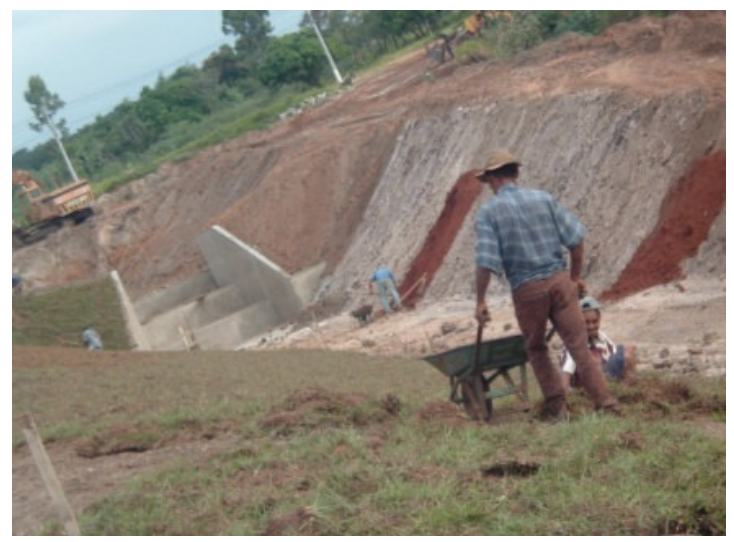

Figura 28. Canal aberto no início de 2005 (Corghi, 2005)

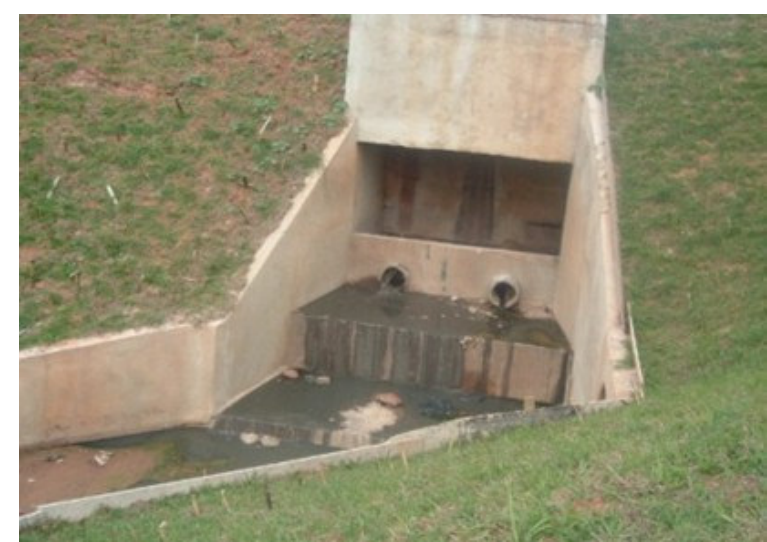

Figura 27. Início de 2005 (Corghi, 2005)

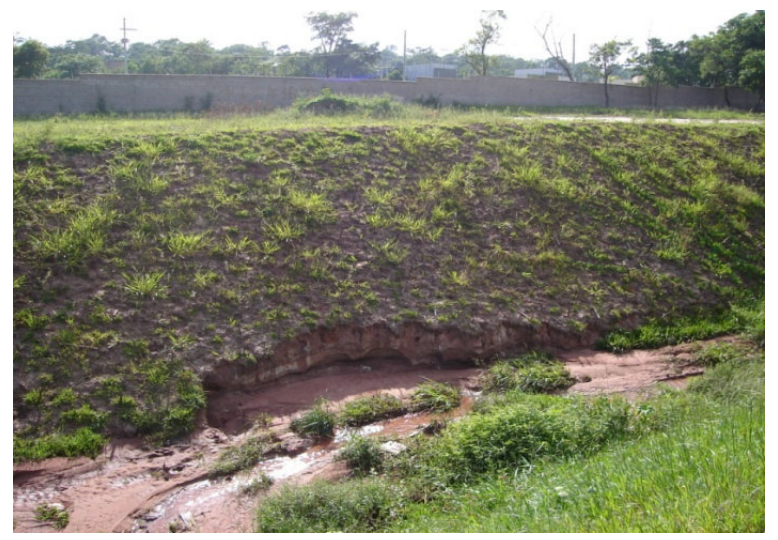

Figura 29. Assoreamento do canal e erosão do talude no final de 2005 


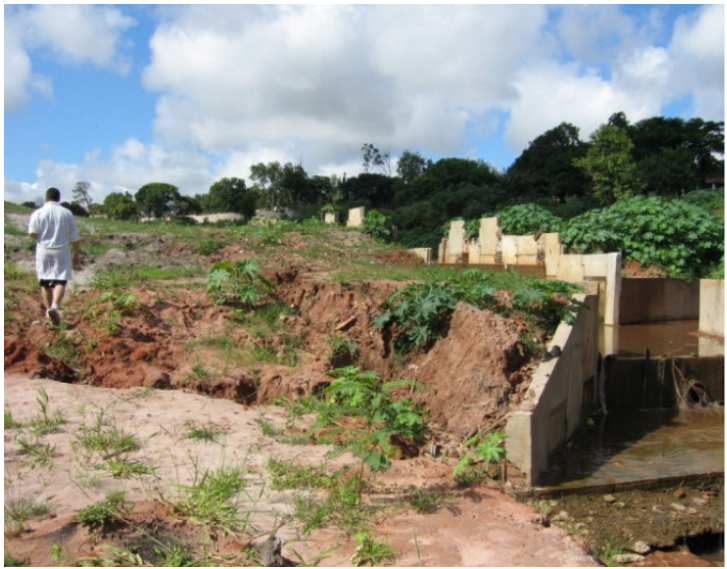

Figura 30. Incisões no terreno ao lado do cachimbo em 2006

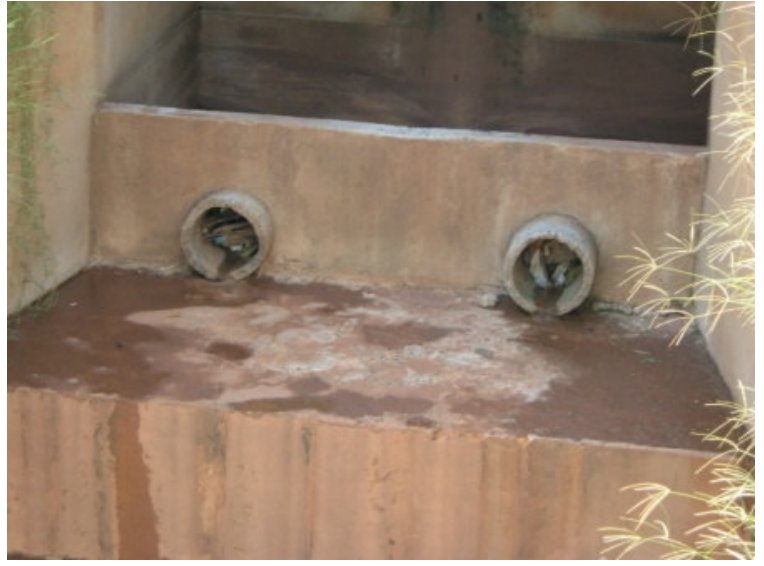

Figura 31. Duto entupido

Com a erosão ao longo do córrego, ocorreu um afloramento d'água lateralmente e nele verificou-se também erosão linear avançada, com ocorrência de escorregamentos e sulcos nos taludes laterais (Figura 32). Como o seu avanço colocava em risco o limite do Residencial Tavano, o local foi aterrado com solo de outras localidades seguindo o nível do terreno imposto pelas construções locais (Figura 33). Dessa forma, o afloramento de água foi controlado e o que se observa atualmente é a presença de grama com pequenas áreas erodidas em forma de sulcos, como pode ser visto na Figura 34.

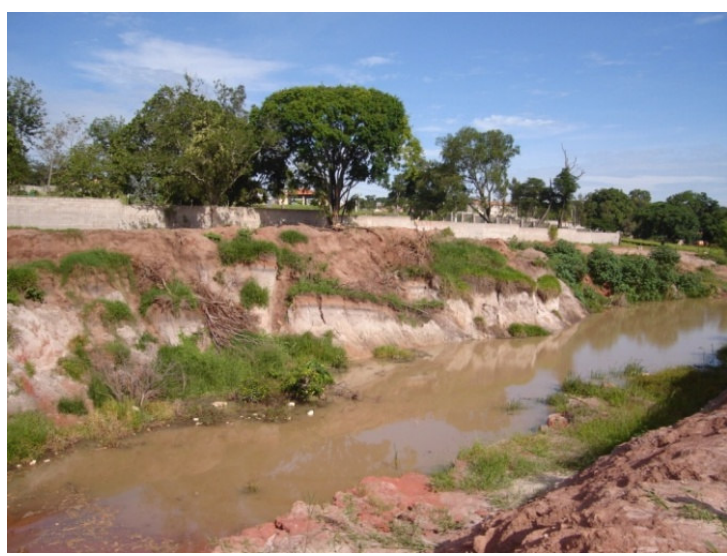

Figura 32. Escorregamento no local de afloramento de água em 2005

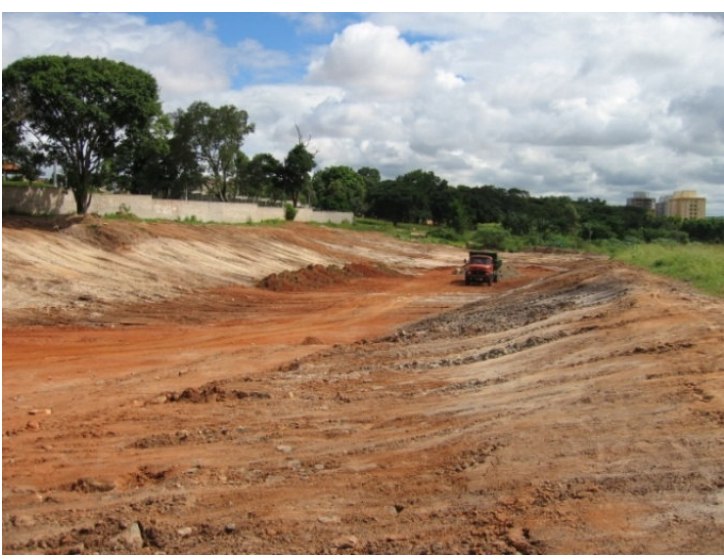

Figura 33. Afloramento de água aterrado em 2006 


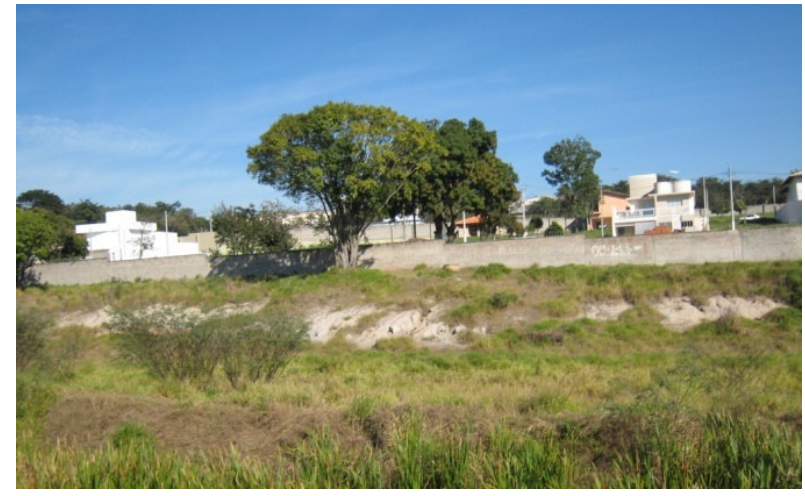

Figura 34. Local onde existia afloramento de água em 2008

Em geral, nas áreas críticas em Bauru constata-se que as obras de contenção do processo erosivo (como paliçadas, diques, aterros e barragens) não são eficientes, ressaltando a falta de maior conhecimento sobre o assunto e rigor no processo de instalação das obras. 


\section{4 - METODOLOGIA}

A pesquisa iniciou-se com o levantamento da bibliografia sobre o assunto e elaboração do texto de revisão sobre o tema do trabalho. A partir deste levantamento, foram escolhidos os ensaios a serem realizados de modo que permitissem a análise do tipo de solo e de argilominerais, que possibilitassem definir as propriedades mecânicas dos mesmos, classificar o solo quanto à sua erodibilidade e avaliar o efeito do fluxo de água no interior do maciço. Os ensaios de laboratório foram: granulometria conjunta, limites de consistência, índices físicos, adsorção de azul de metileno, análise térmica diferencial (ATD), análise termogravimétrica diferencial (ATG), cisalhamento direto, compressão edométrica, Inderbitzen, penetração de cone, absorção de água. Nos subitens a seguir serão apresentadas algumas observações sobre os ensaios, que foram executados em três amostras coletadas em diferentes pontos do processo erosivo (Figura 35).

Em duas áreas, o avanço do processo erosivo no tempo foi avaliado com auxílio de topografia. Além disso, foram executadas sondagens de simples reconhecimento com medida do SPT ao longo das bordas e perpendicularmente ao processo.

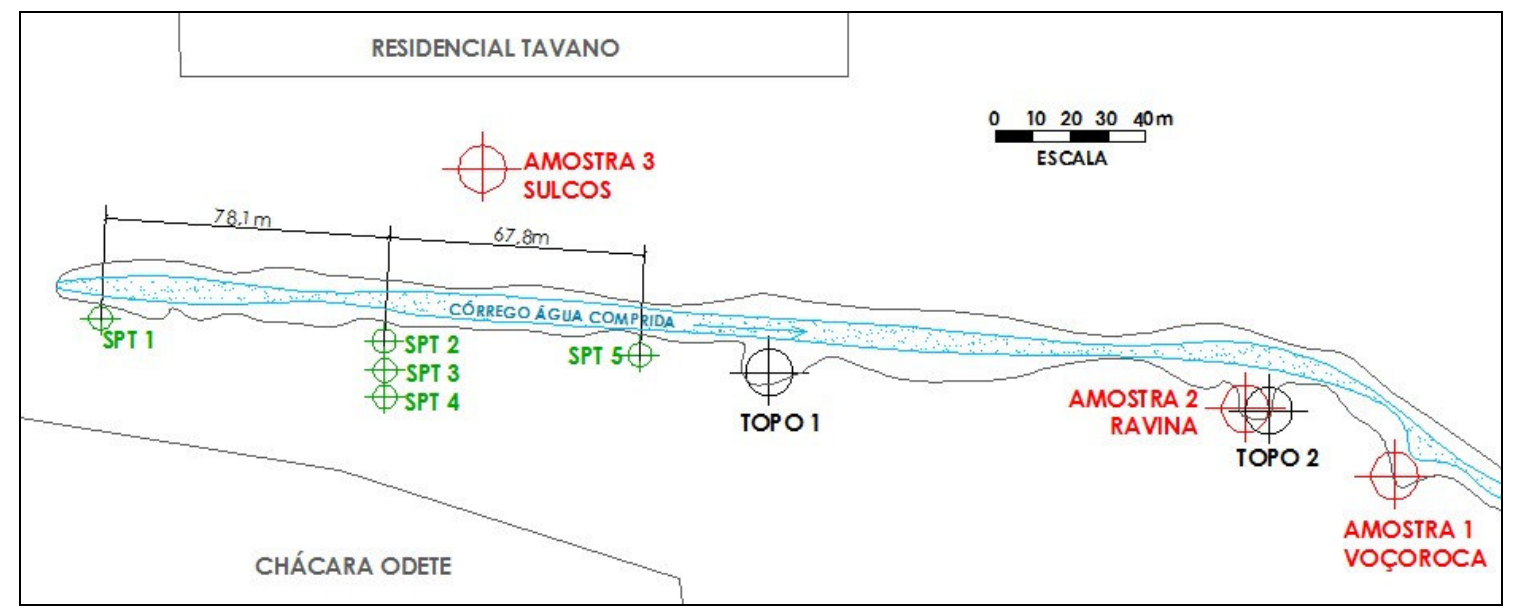

Figura 35. Localização dos ensaios de campo, das amostras coletadas e dos pontos onde foram feitos acompanhamento topográfico. 


\section{1 - Coleta de amostras}

Resultados de ensaios de caracterização realizados previamente por Corghi (2005) e Ide (2006) com material coletado na área em diversos pontos do processo erosivo classificaram o solo como areia média a fina argilosa, com limites de consistência baixos, graus de saturação em torno de $80 \%$. As autoras também realizaram ensaios de erodibilidade do tipo penetração de cone (Alcântara \& Vilar, 1998) e absorção de água (Nogami \& Villibor, 1995) classificando as amostras como altamente erodíveis.

A partir desse estudo, foram selecionados três locais típicos e neles foram coletadas amostras deformadas e indeformadas (Figura 35). Estes locais foram escolhidos devido à reativação do processo, apesar de todas as medidas corretivas aplicadas. Cada amostra representa um tipo estágio da erosão linear: sulco (Am. 3), ravina (Am. 2) e voçoroca (Am. 1), mostrados na Figura 36 a Figura 38.

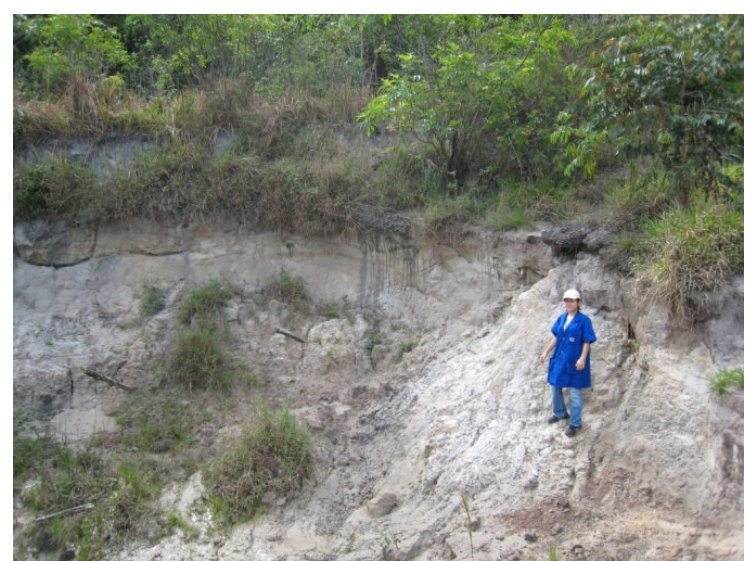

Figura 36. Local de coleta da amostra 1 Voçoroca

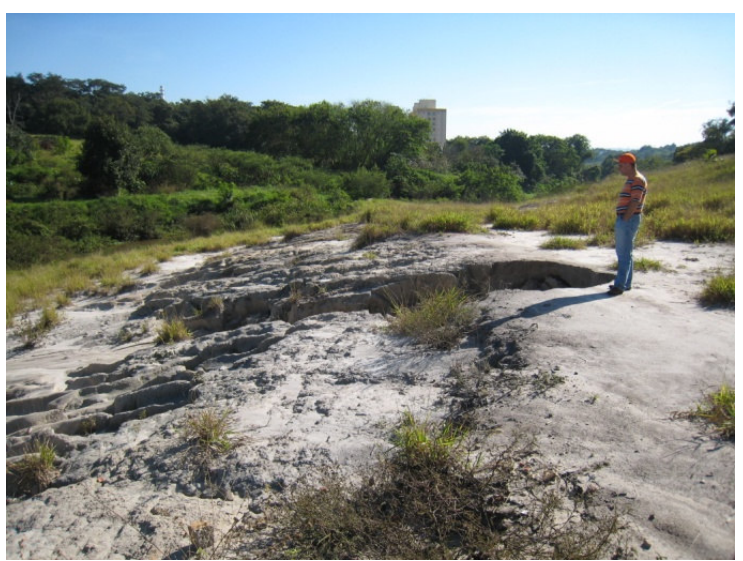

Figura 37. Local de coleta da amostra 2 - Ravina

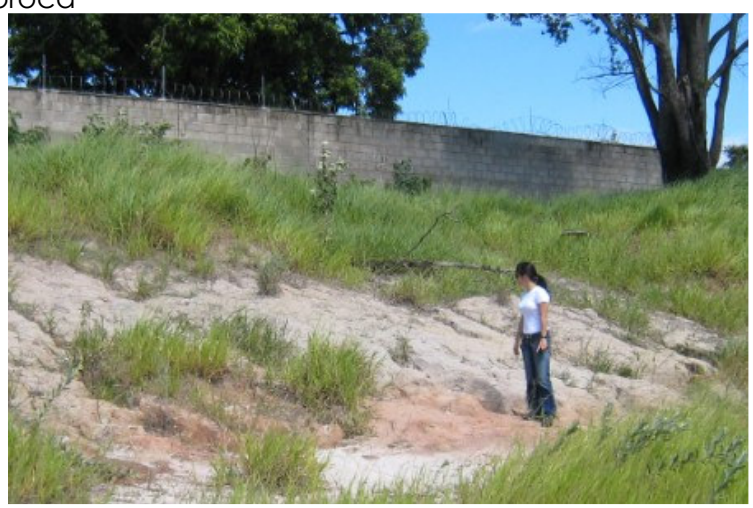

Figura 38. Local de coleta da amostra 3 - Sulcos 
A Amostra 1 foi retirada de um solo residual jovem com características da rocha mãe, representadas pelas lâminas de deposição provenientes do arenito. Homogênea a olho nu, a Amostra 2 se encontra em local de solo sedimentar. Já a Amostra 3 encontra-se em local com solo intermediário entre jovem e maduro, heterogêneo, porém sem características da rocha mãe. Como o solo é evoluído do arenito, ou seja, composto principalmente por quartzo, a pouca mica e feldspato existentes praticamente não são identificados. Além disso, esses minerais sofrem maiores alterações que o quartzo, que é muito resistente ao intemperismo.

Foram coletadas amostras deformadas, para realização dos ensaios de caracterização, e indeformadas, para os ensaios de erodibilidade e mecânicos.

\section{2 - Caracterização}

Para a caracterização física das amostras de solos estudados foram realizados ensaios de granulometria conjunta com e sem defloculante, índices físicos e limites de consistência. Os ensaios de azul de metileno, análise térmica diferencial (ATD), análise termogravimétrica diferencial (ATG), $\Delta \mathrm{pH}$ e curva característica (papel filtro e funil de placa porosa) também foram realizados para caracterizar o solo estudado.

\subsection{1 - Granulometria conjunta}

Na preparação do material ensaiado, o solo foi passado na peneira \#10 (2mm) e deixado em repouso úmido. Após o repouso, transferiu-se a mistura para o dispersor e bateu por $15 \mathrm{~min}$. Recolheu-se a mistura numa proveta de capacidade $1000 \mathrm{~cm}^{3}$ acrescentando água destilada até completar esse volume. O defloculante utilizado no ensaio de sedimentação foi o hexametafosfato de sódio. A suspensão foi homogeneizada e realizaram-se as leituras nos tempos $1,2,3,5,9,15,30,60,120,240$ e 480 minutos. O ensaio seguiu o procedimento da norma da ABNT NBR 7181/84. Também foram realizados ensaios sem defloculante para avaliar o comportamento do solo em campo. 


\subsection{2 - Limites de consistência}

\section{Limite de Liquidez}

Após seco ao ar, o solo foi passado na peneira \#40 $(0,42 \mathrm{~mm})$ e no almofariz. Colocou-se sobre a placa de vidro cerca de $100 \mathrm{~g}$ do material adicionando água suficiente para formar uma pasta. Colocou-se a pasta na concha do aparelho de Casagrande e alisou-se a superfície com a espátula. Abriu-se um sulco $(1 \mathrm{~mm})$ com o cinzel ao longo do plano de simetria do aparelho. Girou-se a manivela 2 golpes por segundo, contando o número de golpes necessários para fechar a ranhura. Retirou-se cerca de $15 \mathrm{~g}$ de solo junto às bordas que se uniram para determinação da umidade. Adicionou-se água em quantidades pré-determinadas e repetiu-se o procedimento 4 vezes. O procedimento corresponde ao da norma da ABNT NBR 6459/84.

\section{Limite de Plasticidade}

Colocou-se em uma cápsula de porcelana cerca de $50 \mathrm{~g}$ de solo e adicionou-se água destilada suficiente para formar uma pasta. Sobre a placa de vidro esmerilhada, rolouse o solo com a mão. Pelo procedimento do ensaio, o mesmo deveria ter sido interrompido quando o bastonete de solo estiver com diâmetro de $3 \mathrm{~mm}$ e ocorrer o aparecimento de fissuras no mesmo, mas devido ao solo não plástico, isso não foi possível. A metodologia de ensaio seguiu a norma NBR 7180/84.

\subsection{3 - Índices físicos dos solos}

Foram feitas determinações de três índices físicos dos solos estudados, de massa específica dos sólidos, do teor de umidade e de massa específica dos solos em laboratório. Os demais índices, como índice de vazios, porosidade, grau de saturação e massa específica seca, foram determinados por fórmulas de correlação.

A massa específica dos sólidos foi determinada segundo a NBR 6508/84 colocandose no picnômetro a amostra de solo e adicionando-se água destilada até, 
aproximadamente, a metade do mesmo $\left(500 \mathrm{~cm}^{3}\right.$ a $\left.20^{\circ} \mathrm{C}\right)$. Para expulsão do ar contido na amostra, ferveu-se o conjunto em banho-maria por 30 minutos, mexendo-o em intervalos regulares de tempo e sempre adicionando água destilada para compensar a evaporação.

O teor de umidade foi determinado utilizando o método da estufa elétrica (NBR 6457/86) e a massa específica natural do solo foi determinada a partir da moldagem de corpos-de-prova dos ensaios de cone de penetração, com a medição da massa das amostras e de suas dimensões.

\subsection{4 - Azul de metileno}

O ensaio de azul de metileno foi realizado a fim de analisar os tipos de argilominerais presentes nas amostras de solo. A metodologia seguida foi a de Pejon (1992), cuja quantidade de cada material utilizado no ensaio está presente na Tabela 1.

Tabela 1 - Quantidades dos materiais utilizadas no método de Pejon (1992)

\begin{tabular}{lc}
\hline \multicolumn{1}{c}{ Variável } & Quantidade \\
\hline Solução de azul de metileno (azul/água destilada) & $0,15 \mathrm{~g}$ para $100 \mathrm{~mL}$ \\
Amostra $(\mathrm{g})$ & 2 a 4 \\
Água destilada $(\mathrm{mL})$ & 10 \\
Solução inserida $(\mathrm{mL})$ & 3 \\
Tempo de reação $(\mathrm{min})$ & 3 \\
\hline
\end{tabular}

A amostra deve ser previamente seca ao ar até seu peso ficar constante. Pesa-se pequena quantidade de amostra homogeneizada (0,5 a 1 grama) e coloca-se no béquer, adiciona-se $10 \mathrm{ml}$ de água destilada e agita-se o conjunto para homogeneização. Após passar pelo agitador magnético por durante três minutos, adiciona-se $1 \mathrm{ml}$ da solução de azul de metileno ao béquer e cronometra-se o tempo. O agitador deve ser mantido ligado durante todo o ensaio. Mantém-se a suspensão solo+água+azul de metileno em agitação constante por 3min, em seguida é retirada uma gota da suspensão com o bastão de vidro e colocada cuidadosamente sobre o papel de filtro.

Caso o teste seja negativo (não apresentar um anel mais claro ao redor), o procedimento é repetido quantas vezes forem necessárias para que se atinja o ponto onde o teste seja positivo. Ao se atingir este ponto, aguarda-se mais 3 minutos e realiza-se 
novamente o teste para a confirmação. Se for positivo o ensaio está encerrado. Caso seja negativo, prossegue-se com o procedimento até o resultado positivo.

\subsection{5 - ATD e ATG}

O método de análise térmica diferencial (ATD) consiste no aquecimento de uma amostra de argila em velocidade constante juntamente com uma substância termicamente inerte (óxido de alumínio), com registros das transformações endo ou exotérmicas da argila em relação ao padrão inerte. O aparelho de ATD possui três "portas-amostras". Em dois deles são acondicionadas a alumina calcinada $\left(\mathrm{Al}_{2} \mathrm{O}_{3}\right)$, no terceiro é acondicionada a amostra a ser analisada. Os materiais devem ser levemente compactados, para que se obtenha uma homogeneização.

O gradiente de variação de temperatura é ajustado, assim como a temperatura final do ensaio. Nos ensaios executados foi adotada uma variação de $12,5^{\circ} \mathrm{C} / \mathrm{min}$ e temperatura final de $1000^{\circ} \mathrm{C}$. O ensaio é controlado automaticamente por um software desenvolvido para este fim e sua realização é contínua até o final sem a interferência do laboratorista.

Obtém-se assim uma tabela de temperatura em graus Celsius em função da deflexão do galvanômetro onde as ordenadas positivas são as deflexões correspondentes as transformações exotérmicas e as ordenadas negativas, às transformações endotérmicas (Santos, 1989).

A preparação da amostra para o ensaio de análise termogravimétrica diferencial (ATG) é a mesma utilizada para o ATD. O aparelho utilizado para a análise de ATD e ATG está mostrado na Figura 39. 


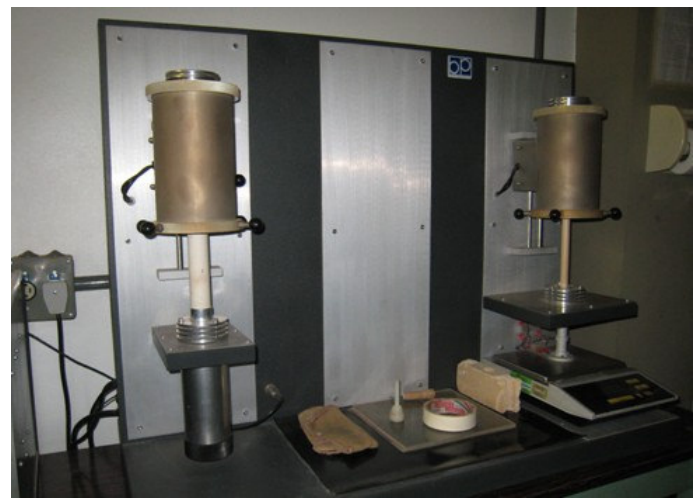

Figura 39. Aparelho do ensaio ATD e ATG

\subsection{6 - $\Delta \mathrm{pH}$ do solo}

$\mathrm{O}$ pH do solo é medido em solução com água destilada e $\mathrm{KCl} 1 \mathrm{M}$, separadamente. A relação solo-solução é de 1:2,5 (Camargo et al., 1986). Logo, a quantidade de solo utilizada foi de $50 \mathrm{~g}$ para $125 \mathrm{ml}$ de água ou $\mathrm{KCl}$, que foi posteriormente agitada por $30 \mathrm{~min}$. Após, a solução foi deixada em repouso por 60min e, assim, foram realizadas as medidas de pH com auxílio de um peagâmetro.

$\mathrm{O}$ valor do $\Delta \mathrm{pH}$ é dado pela diferença entre $\mathrm{O} \mathrm{pH}$ em $\mathrm{KCl}$ e em $\mathrm{H}_{2} \mathrm{O}$ e permite analisar o estágio de intemperização do solo, que aumenta quanto maior a quantidade de finos presentes no solo.

Para resultados menores que zero, há predominância de cargas negativas no solo, ou seja, ele possui maior capacidade de absorção de cátions. Já para resultados maiores que zero, as cargas positivas são predominantes. Nesse último caso, o teor de oxi-hidróxidos de ferro e alumínio é maior que o de argilominerais, o que ressalta o fato do solo estar em estágio avançado de intemperização.

\subsection{7 - Curva característica}

A curva característica foi determinada através da união dos resultados do método do papel filtro e do funil de placa porosa. Inicialmente, pretendia-se realizar somente ensaios de papel filtro, entretanto, ele mostrou-se ineficiente para umidades próximas à de 
saturação, ou seja, para sucções muito baixas. Devido ao fato, o ensaio de funil de placa porosa foi realizado porque permite definir os valores de umidade correspondentes a baixos valores de sucções pré-determinadas. A determinação da curva característica é importante para o estudo de solos não saturados porque permite relacionar um índice físico do solo (umidade ou grau de saturação) com sua sucção matricial.

\section{Papel filtro}

A sucção matricial foi determinada pelo método do papel filtro, descrito por Marinho (1995). Para evitar o efeito da histerese, os corpos-de-prova foram previamente saturados por 24 horas sobre uma placa porosa em um recipiente com água destilada até a metade de sua altura. Cada um foi seco ao ar até atingir o valor massa desejado, que corresponde a certa umidade escolhida previamente. Após isso, foram embalados com papel filtro Whatman $n^{\circ} 42$ em ambas as faces da amostra (Figura 40), de modo que o papel só ficasse em contato com o solo. Para garantir o contato, discos de PVC foram dispostos sobre o papel. O conjunto foi embalado com papel filme e deixado em ambiente isolado termicamente até atingir o equilíbrio da sucção (aproximadamente de 7 a 10 dias).

Passado o tempo necessário, foram medidas as umidades do papel filtro e do corpode-prova. Para que a umidade do papel não fosse afetada, o que causaria mudanças no resultados de sucção, foi utilizado um recipiente de isopor no transporte entre a estufa e a balança de precisão 0,0001g. Através da umidade do papel ( $\left.W_{p}\right)$ estimou-se a sucção matricial do solo $(\Psi)$ utilizando-se as equações propostas por Chandler et al. (1992).

Para $w_{p}>47 \%$ :

$$
\Psi(\mathrm{kPa})=10(6.05-2.48 \log \mathrm{wp})
$$

para $w_{p} \leq 47 \%$ :

$$
\Psi(\mathrm{kPa})=10(4.84-0.0622 \mathrm{wp})
$$


Com os pares de pontos de sucção por umidade foi determinada a curva de retenção do solo com auxílio do software RETC® e ajuste proposto por Van Genutchen (1980).

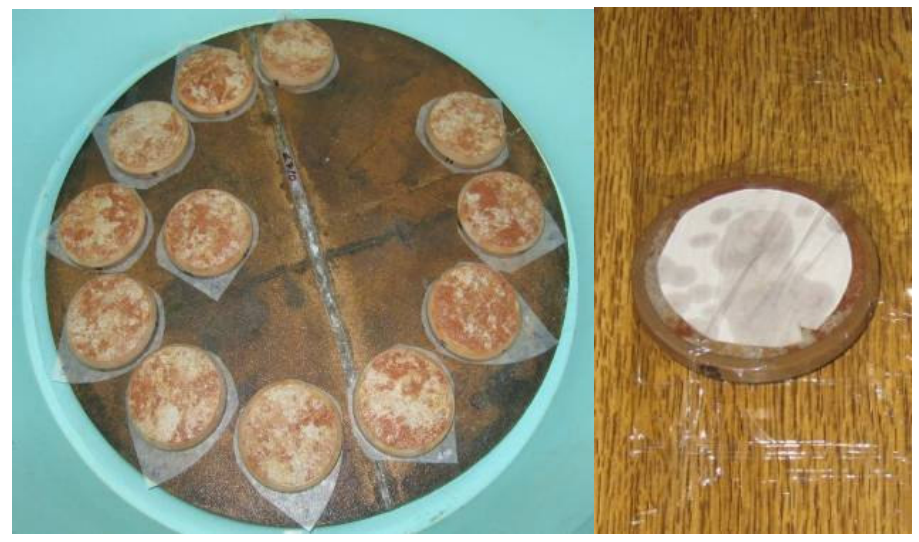

Figura 40. Saturação dos corpos-de-prova e detalhe do papel filtro em contato com o corpo-deprova.

\section{Funil de placa porosa}

O equipamento consiste num funil provido de uma placa porosa e de um tubo flexível através do qual se impõem gradientes de altura pela redução ou elevação do nível d'água de um reservatório acoplado ao funil (Rodrigues, 2007). Proposto por Libardi (1995), esse ensaio impõe sucção no solo colocando-se uma amostra saturada sobre a placa porosa e rebaixando o nível d'água do reservatório até o nível desejado, de forma que ocorra drenagem por um furo no reservatório, lembrando que o sistema deve estar saturado de água destilada antes de se colocar a amostra. O fluxo é interrompido quando a amostra atinge a sucção pré-determinada, ou seja, quando o sistema entra em equilíbrio e a água não é mais expulsa do reservatório. Então é determinada a umidade do corpo-de-prova correspondente à sucção imposta. 


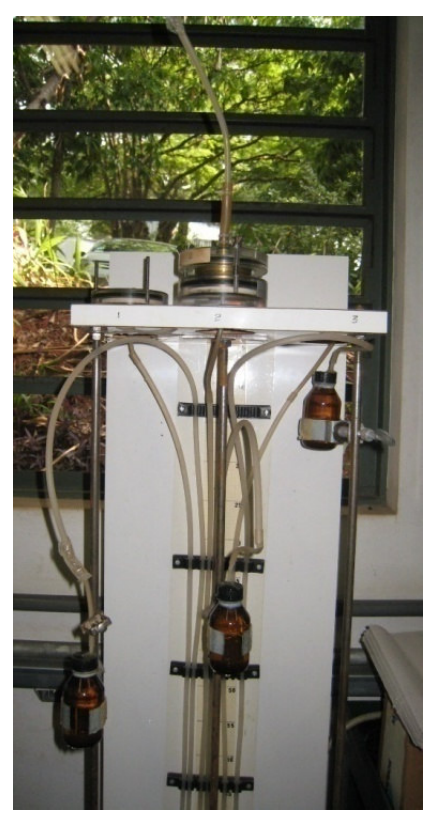

Figura 41. Ensaio de funil de placa porosa para determinação da curva característica do solo

\section{3 - Propriedades mecânicas}

Na determinação dos parâmetros de resistência, foram realizados ensaios de compressão edométrica, para avaliar o histórico de tensões do solo, e de cisalhamento direto na condição natural e inundada, para estudar o efeito da variação da sucção matricial na resistência. Foi necessário realizar ensaios de cisalhamento ao invés de triaxiais porque os solos estudados não possibilitaram a preparação de corpos de prova cilíndricos para o último, por serem muito arenosos.

\subsection{1 - Compressão edométrica}

Para avaliação do histórico de tensões, ensaios de compressão edométrica foram realizados em amostras na umidade natural e na condição inundada. Nele foram aplicados os seguintes estágios de carga; 3,6; 7,2; 14,8; 25; 50; 100; 200; 400 e 800kPa. Em cada estágio, espera-se a estabilização das variações verticais. O procedimento do ensaio está descrito na NBR 12007/90. 


\subsection{2 - Cisalhamento direto}

Nesse ensaio determinam-se as tensões e deslocamentos verticais e horizontais do corpo de prova em vários estágios de carregamento (tensões verticais correspondentes a $27 \mathrm{kPa}, 54 \mathrm{kPa}, 109 \mathrm{kPa}$ e $218 \mathrm{kPa})$. Assim, determina-se a envoltória de resistência e, conseqüentemente, a coesão e o ângulo de atrito. Os corpos-de-prova são quadrados e possuem dimensões de $60 \mathrm{~mm}$ de lado e $20 \mathrm{~mm}$ de altura. O procedimento de ensaio seguido é descrito por Stancati et al. (1981). A velocidade de ensaio utilizada foi de $0,3 \mathrm{~mm} / \mathrm{s}$. Pelas características dos corpos-de-prova considera-se que esse ensaio é do tipo lento.

\section{4 - Erodibilidade}

A erodibilidade indica o grau de facilidade com que as partículas de solo destacamse e são transportadas, fator que contribui para a erosão do solo, principalmente pela ação da água. Foram realizados três tipos de ensaio de erodibilidade: Inderbitzen, metodologia MCT (absorção de água e perda por imersão) e penetração de cone, descritos a seguir.

\subsection{1 - Inderbitzen}

Inderbitzen (1961) propôs um método de ensaio que possibilita avaliar a medida da erodibilidade através da determinação da taxa de erosão do solo sob condições variáveis de escoamento, inclinação da superfície e teor de umidade do solo. O ensaio consiste em submeter uma amostra de solo indeformada nivelada na superfície da rampa à ação da água, controlando o fluxo até um máximo de $2 \mathrm{~h}$ de duração. A perda depende do tipo de solo, das condições do ensaio e das características da amostra.

No estudo de solos do Distrito Federal, Fácio (1991) procurou estabelecer uma metodologia padrão a partir de uma série de ensaios variando os valores de vazão, declividade da rampa e tempo de duração do ensaio. A partir dos resultados obtidos, o autor propôs uma rampa de $0,33 \mathrm{~m}$ de largura por 1,30m de comprimento e declividade de $10^{\circ}$, na qual percola-se uma vazão de $50 \mathrm{ml} / \mathrm{s}$. A amostra, nivelada com a superfície da 
rampa, possui 100mm de diâmetro e é embebida por 15 minutos, a fim de anular o efeito de eventuais forças de sucção presentes no estado natural. A duração dos ensaios realizados foi de 20 minutos com a utilização de peneiras $n^{\circ} 50,100$ e 200 . O autor sugere ainda que os gráficos sejam expressos em perda acumulada de solo $\left(\mathrm{g} / \mathrm{cm}^{2}\right)$ versus tempo de duração (min).

Além disso, Santos (1997, apud Ramidan, 2003) sugeriu uma modificação na largura da rampa, de modo que esta deveria ter o diâmetro do corpo-de-prova, assegurando que todo o fluxo de água passe sobre a amostra. Em conseqüência, a vazão nesse ensaio foi alterada para $17,5 \mathrm{~mL} / \mathrm{s}$ e o tempo total para 30 minutos.

Dessa forma, o equipamento construído e utilizado nessa pesquisa (Figura 42) é uma mistura entre o proposto inicialmente por Inderbitzen e a simulação do impacto da gota, com a largura da rampa próxima ao diâmetro do corpo-de-prova, obtendo-se assim a avaliação da erodibilidade do solo tanto pela ação da gota, como pelo escoamento laminar, representando mais fielmente as condições de campo.

Como as dimensões da rampa propostas por Fácio (1991) eram muito grandes para a adaptação do sistema que simula o impacto da gota, elas foram reduzidas para $500 \mathrm{~mm}$ de comprimento e $110 \mathrm{~mm}$ de largura, que é a mais próxima possível da largura do corpode-prova, o qual possui altura de $5 \mathrm{~cm}$. As peneiras utilizadas foram as de $\mathrm{n}^{\circ} 50,100$ e 200 . A vazão de ensaio foi mantida no padrão de Fácio (1991), ou seja, foi de 50ml/s.

Para reproduzir as condições campo, as amostras foram ensaiadas com diferentes ângulos de inclinação $\left(15^{\circ}\right.$ e $\left.31^{\circ}\right)$. Além disso, elas foram analisadas em inclinações variáveis às de campo, para possibilitar a comparação. A inclinação de $50^{\circ}$ foi utilizada, pois existem taludes negativos em certos pontos ao longo do processo erosivo e essa é a maior inclinação possível do equipamento. 


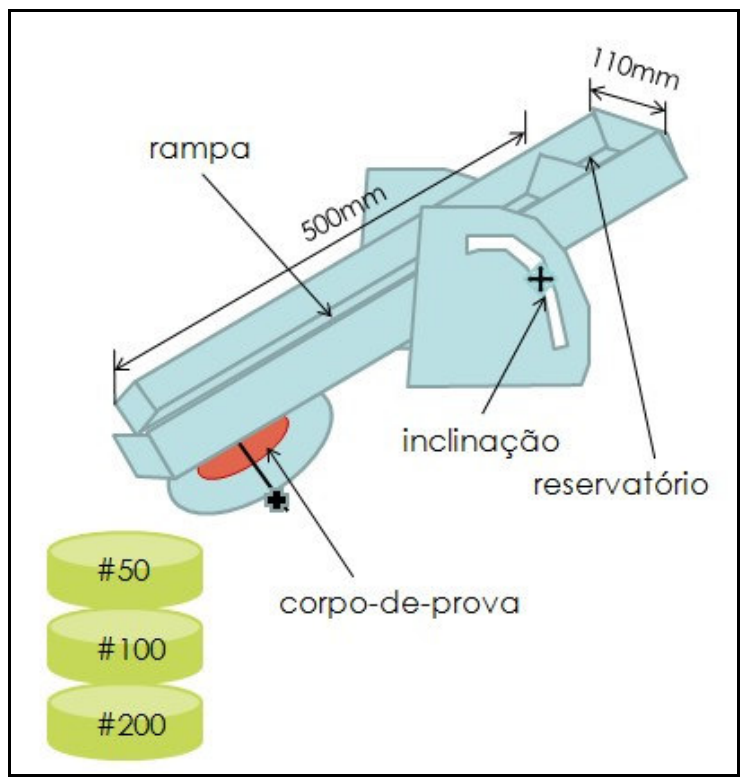

a) representação esquemática

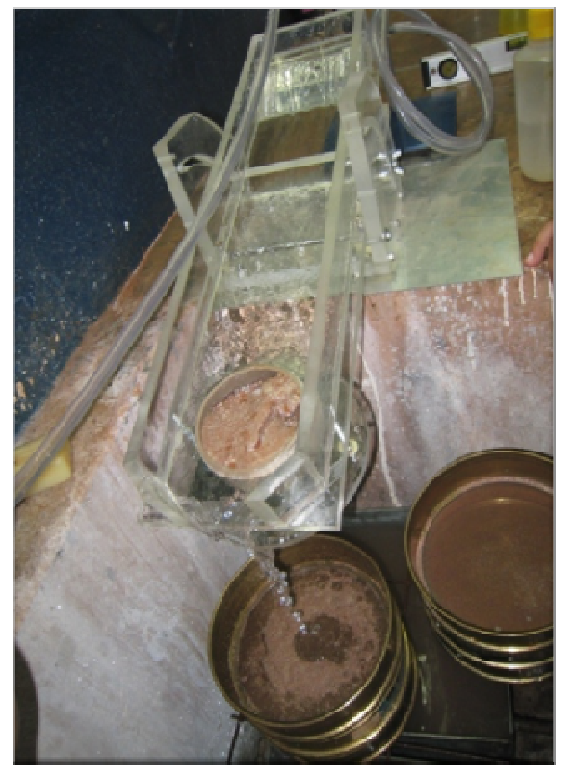

b) realização do ensaio

Figura 42. Equipamento Inderbitzen construído

Como proposto por Inderbitzen (1961), um "chuveiro" foi utilizado na simulação da ação das gotas de chuva. As gotas foram distribuídas de forma a caírem somente sobre o corpo-de-prova e, nesse caso, não houve escoamento laminar, ou seja, toda a vazão foi direcionada à simulação da ação da chuva. Antônio (2007) explica que a máxima chuva ocorrida em Bauru no ano de 1993 corresponde a intensidade de $28 \mathrm{~mm}$ em meia hora. Porém, não foi possível reproduzir o fenômeno, pois a vazão necessária é muito baixa e inviável ao equipamento desenvolvido. Por isso, foi mantida a vazão de $50 \mathrm{ml} / \mathrm{s}$ utilizada no ensaio convencional (escoamento superficial) para efeitos comparativos, apesar de extrapolar significativamente uma condição de chuva real.

Mendes (2006) observou que a maior perda de solo nos primeiros cinco minutos do ensaio, vindo a se estabilizar próximo a 10 minutos. Porém, como outros trabalhos mostraram que essa estabilização pode não ocorrer, dependendo do tipo de solo analisado, a duração do ensaio realizado foi de 30 minutos, seguindo proposta de Santos (1997, apud Ramidan, 2003). Assim, foi possível uma maior caracterização da curva perda de solo pelo tempo. 
Ramidan (2003) estudou uma voçoroca causada pela remoção de uma camada de solo argiloso em Itumbiara-GO. Entre os ensaios para avaliar a erodibilidade do solo, utilizou o Inderbitzen e verificou que a maior quantidade de perda de solo ocorre nos 5 minutos iniciais de cada ensaio. Por isso, as peneiras utilizadas foram trocadas em 1, 5, 10, 20 e 30 minutos, permitindo uma melhor definição da curva no início de ensaio, que é quando ocorrem as maiores perdas de solo,

Os resultados dos ensaios são expressos em termos de perdas de solo $\mathrm{x}$ tensão cisalhante aplicada $\left(\tau_{H}\right)$. A partir do ajuste das retas são identificados os parâmetros de erodibilidade $(K)$, que representa $\circ$ gradiente de perda do solo em relação às tensões hidráulicas aplicadas, e a tensão crítica de cisalhamento $\tau_{\text {Hcrit, }}$ que corresponde ao valor de $\tau_{H}$ para erosão nula (Figura 43 ).

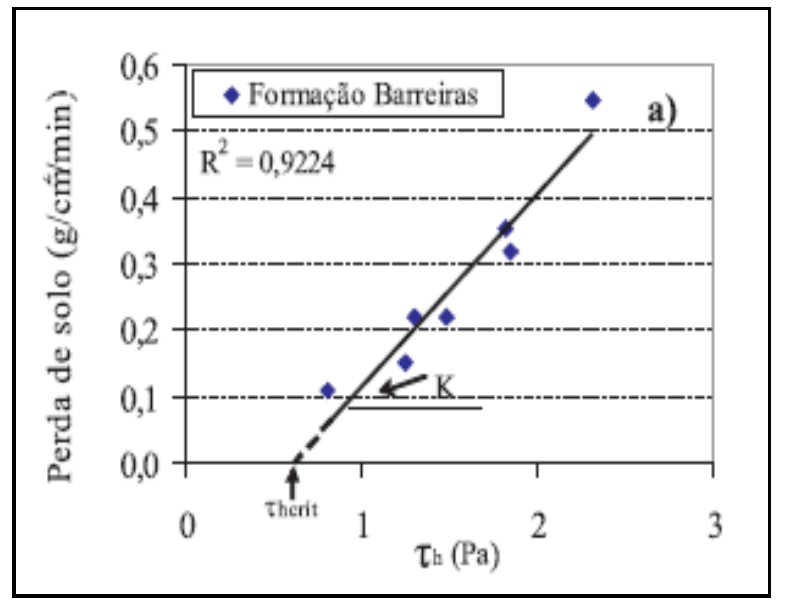

Figura 43. Representação da perda de solo versus tensão cisalhante aplicada no ensaio Inderbitzen (Lafayette et al., 2005)

A tensão cisalhante $\left(\tau_{H}\right)$ foi calculada segundo a equação 3 , na qual $\gamma$ é o peso específico da água, h é a altura e $d$ a declividade.

$$
\tau_{H}=\gamma . h . d
$$




\subsection{2 - Absorção de água e perda por imersão}

O ensaio para avaliar a erodibilidade segundo a metodologia MCT foi desenvolvido para erosão em taludes rodoviários e baseia-se nos resultados de ensaios de absorção d'água e perda de massa por imersão de corpos-de-prova miniatura (Nogami \& Villibor, 1979). Nesse ensaio, mede-se o volume de água absorvido pelo corpo de prova em função do tempo, por cerca de 1 hora. Logo após, realiza-se o ensaio de perda por imersão por um período de 24 horas. Os corpos-de-prova são moldados a partir de amostras indeformadas com dimensões de $53 \mathrm{~mm}$ de diâmetro e $50 \mathrm{~mm}$ de altura.

O índice de absorção (S) é o coeficiente angular do trecho inicial entre volume de água absorvido dividido pela área do corpo-de-prova e a raiz do tempo (Figura 59). Para avaliar a erodibilidade do solo é utilizado um gráfico de perda por imersão (Pi) versus índice de absorção. Nogami \& Villibor (1995) propõem um limite no qual E=52S/Pi, amostras acima dessa relação são classificadas como de alta erodibilidade. Porém, Pejon (1992) desenvolveu pesquisas nas quais sugere o limite de 40S/Pi. É importante ressaltar que os Nogami \& Villibor (op. cit.) estudaram solos do estado de São Paulo e Pejon estudou solos da região de Piracicaba especificamente.

\subsection{3 - Penetração de cone}

Nesse ensaio (Figura 44), os corpos-de-prova foram ensaiados com peso em forma de cone de $300 \mathrm{~g}$ liberado a $10 \mathrm{~mm}$ de altura do corpo de prova. Para cada anel moldado, foram feitas 9 leituras de penetração e, assim, fez-se a média dos corpos de prova em condição natural (Pnat) e dos saturados (Psat). Foram moldados 6 corpos de prova de cada amostra no campo, tendo assim 3 com as características do solo natural e 3 saturados por uma hora.

Após o cálculo da média, efetuou-se o cálculo da variação de penetração (DP), obtido pela equação 4, e comparou-se o resultado com a variação limite(DPlimite) indicada 
por Alcântara e Vilar (1998), obtida pela equação 5. Para valores de DP maiores que DPlimite, a erodibilidade é alta; caso contrário, ela é baixa.

$$
\begin{aligned}
& \text { DP }=(\text { Psat-Pnat }) / \text { Pnat } \\
& \text { DPlimite }=4,5 . \text { Pnat }
\end{aligned}
$$
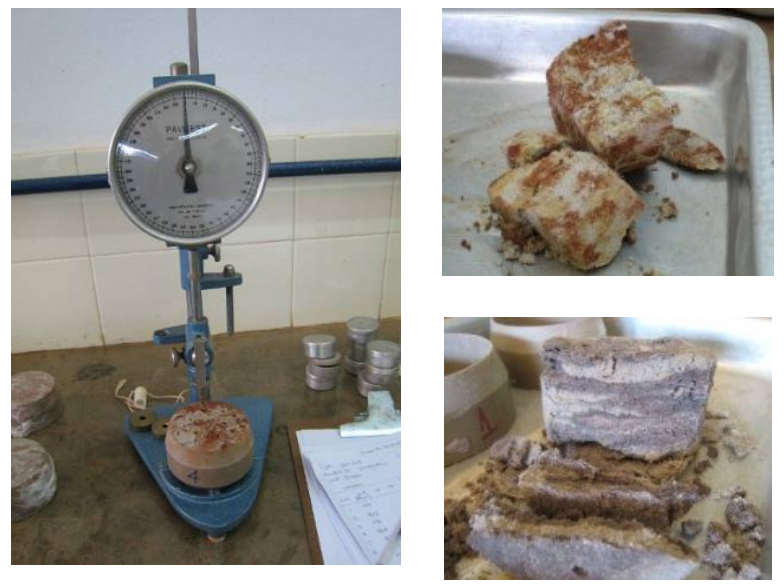

Figura 44. Ensaio de cone e heterogeneidade da amostra 3 (superior) e 1 (inferior)

Para as amostras 1 e 3 (homogêneas a olho nu), o limite de $\pm 5 \%$ em relação à média para descarte das leituras não foi levado em conta, pois desconsiderava uma grande quantidade de leituras de penetrações do cone metálico.

\section{5 - Ensaios de campo}

Foram realizados cinco ensaios de sondagem de simples reconhecimento com medida do SPT (Figura 45), conforme ABNT NBR 6484/01, por uma empresa contratada para esse fim. Assim, foi possível representar o perfil longitudinal e transversal às bordas do processo, além de amostras de solo com a profundidade para análise das características do solo. Com as amostras coletadas nessas sondagens, foram realizados ensaios de granulometria conjunta com e sem defloculante e de $\Delta \mathrm{pH}$. 


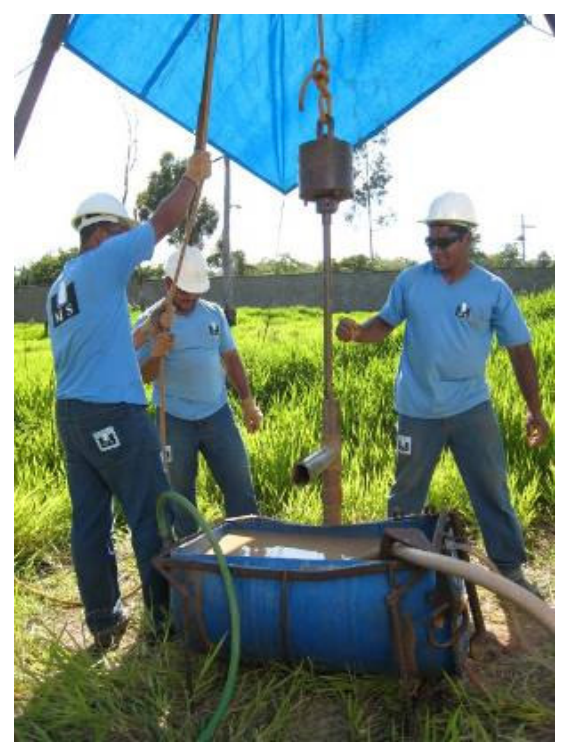

Figura 45. Realização das sondagens de simples reconhecimento na área de pesquisa 


\section{5 - RESULTADOS}

Os resultados de todos os ensaios realizados na área em estudo serão apresentados nesse capítulo e foram subdivididos em itens chamados: caracterização, erodibilidade, parâmetros mecânicos e ensaios de campo.

\section{1 - Caracterização}

A seguir estão presentes os resultados dos ensaios de granulometria conjunta, limites de consistência, massa específica dos sólidos, azul de metileno, ATD/ATG, $\Delta \mathrm{pH}$ e curva característica.

\subsection{1 - Granulometria conjunta}

$\mathrm{Na}$ Figura 46 a Figura 48, encontram-se as curvas granulométricas com e sem defloculante dos três amostras de solos ensaiados. Verifica-se que todas as amostras são classificadas como areia média a fina pouco argilosa, apesar da Amostra 3 apresentar cerca de $4 \%$ a mais de finos nas curvas com defloculante (Figura 48). Observa-se que, nas curvas sem defloculante, não há presença da fração argilosa, ressaltando a influência da agregação dos argilominerais, que atuam como grãos de maior dimensão. 


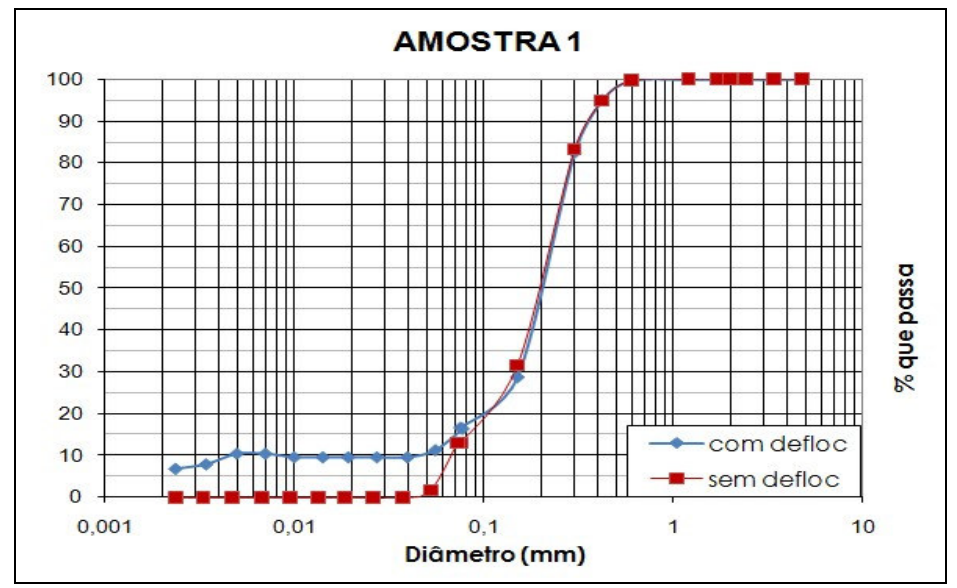

Figura 46. Curvas granulométricas da amostra 1 com e sem defloculante

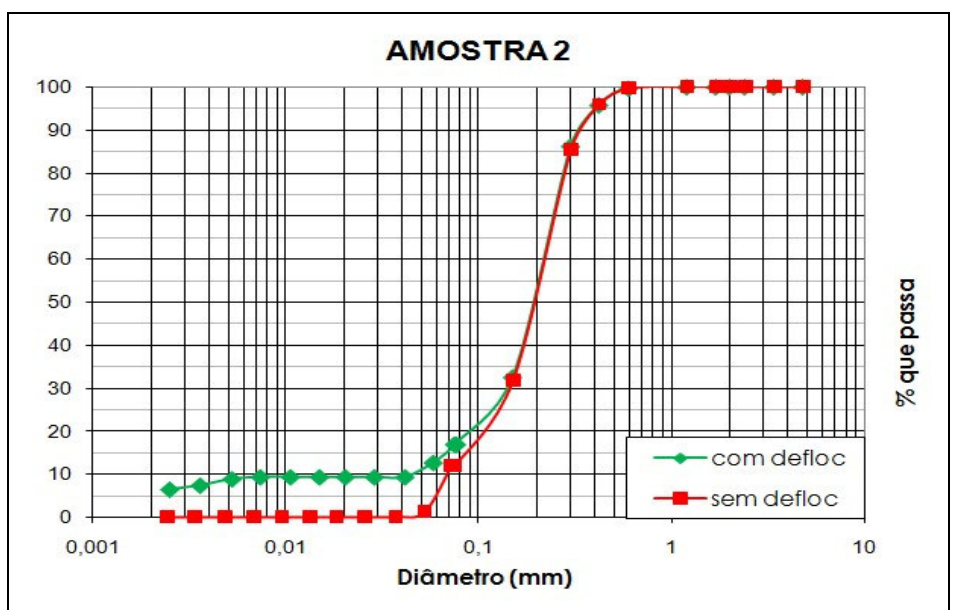

Figura 47. Curvas granulométricas da amostra 2 com e sem defloculante

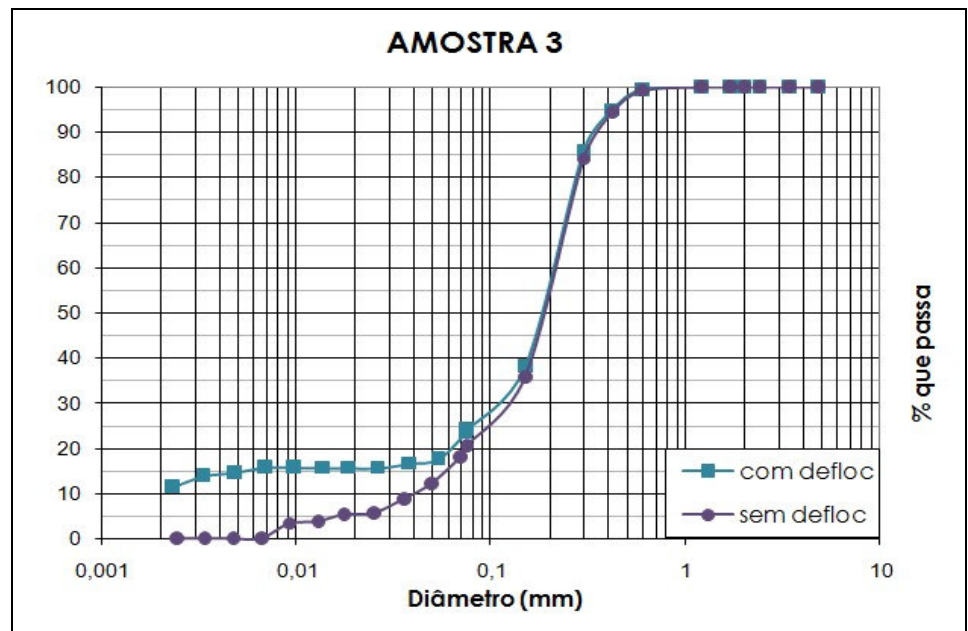

Figura 48. Curvas granulométricas da amostra $3 \mathrm{com}$ e sem defloculante 


\subsection{2 - Limites de consistência}

Na Tabela 2 estão apresentados os limites de consistência determinados para cada uma das amostras ensaiadas. Observa-se que as amostras 1 e 2 não permitiram a determinação do limite de plasticidade, pois não são plásticas, diferentemente da amostra 3, que apresentou um índice de plasticidade igual a $10 \%$.

\begin{tabular}{cccc} 
Tabela $2-$ Limites de consistência das amostras estudadas \\
\cline { 2 - 4 } Amostra & LL & LP & IP \\
& $(\%)$ & $(\%)$ & $(\%)$ \\
\hline 1 & 12,7 & NP & - \\
2 & 15,4 & NP & - \\
3 & 25,5 & 15,3 & 10,0 \\
\hline
\end{tabular}

\subsection{3 - Índices físicos}

Na Tabela 3 são apresentados os resultados da massa específica natural, teor de umidade e massa específica dos sólidos. Os resultados obtidos para massa específica dos sólidos ( $\left.\rho_{s}\right)$ são característicos de materiais arenosos, próximos a $2,7 \mathrm{~g} / \mathrm{cm}^{3}$.

\begin{tabular}{|c|c|c|c|}
\hline Amostra & $\begin{array}{c}\rho \\
\left(\mathrm{g} / \mathrm{cm}^{3}\right)\end{array}$ & $\begin{array}{l}W \\
(\%)\end{array}$ & $\begin{array}{c}\rho_{\mathrm{s}} \\
\left(\mathrm{g} / \mathrm{cm}^{3}\right)\end{array}$ \\
\hline 1 & 1,991 & 14,3 & 2,694 \\
\hline 2 & 2,021 & 13,8 & 2,688 \\
\hline 3 & 1,922 & 12,1 & 2,702 \\
\hline
\end{tabular}

\subsection{4 - Azul de metileno}

Apesar da pequena quantidade de argila presente nas amostras analisadas, foram realizados ensaios para determinar o tipo de argilomineral, sua atividade e outras informações possíveis. A partir da massa de solo seco e do volume de azul utilizados, podese calcular os valores correspondentes à atividade da fração argila, o valor de azul de metileno, a superfície específica e a capacidade de troca catiônica, que representa o resultado para $100 \mathrm{~g}$ de solo. Os resultados obtidos para as três amostras ensaiados são apresentados na Tabela 4. 
Tabela 4 - Resultados do ensaio de adsorção de azul de metileno

\begin{tabular}{cccccccc}
\hline Amostra & $\begin{array}{c}\text { Argila } \\
(\%)\end{array}$ & $\begin{array}{c}\text { Massa } \\
(\mathrm{g})\end{array}$ & $\begin{array}{c}\text { Volume } \\
(\mathrm{ml})\end{array}$ & $\begin{array}{c}\text { Acb } \\
(\mathrm{g} / 100 \mathrm{~g})\end{array}$ & $\begin{array}{c}\mathrm{Vb} \\
(\mathrm{g} / 100 \mathrm{~g})\end{array}$ & $\begin{array}{c}\mathrm{SE} \\
(\mathrm{m} 2 / \mathrm{g})\end{array}$ & $\begin{array}{c}\mathrm{CTC} \\
(\mathrm{meq} / 100 \mathrm{~g})\end{array}$ \\
\hline 1 & 7 & 2,4619 & 8,0 & 6,963 & 0,487 & 11,926 & 1,524 \\
2 & 7 & 2,5405 & 7,0 & 5,904 & 0,413 & 10,112 & 1,292 \\
3 & 11 & 2,0927 & 13,0 & 8,471 & 0,932 & 22,799 & 2,913 \\
\hline
\end{tabular}

\subsection{5 - ATD e ATG}

A Figura 49 a Figura 51 apresentam os resultados de análise térmico diferencial (ATD) respectivamente para as amostras 1, 2 e 3. Os resultados permitiram determinar o tipo de argilomineral (caulinita) de forma direta e não através de correlações de resultados, como ocorre no ensaio de adsorção de azul de metileno.

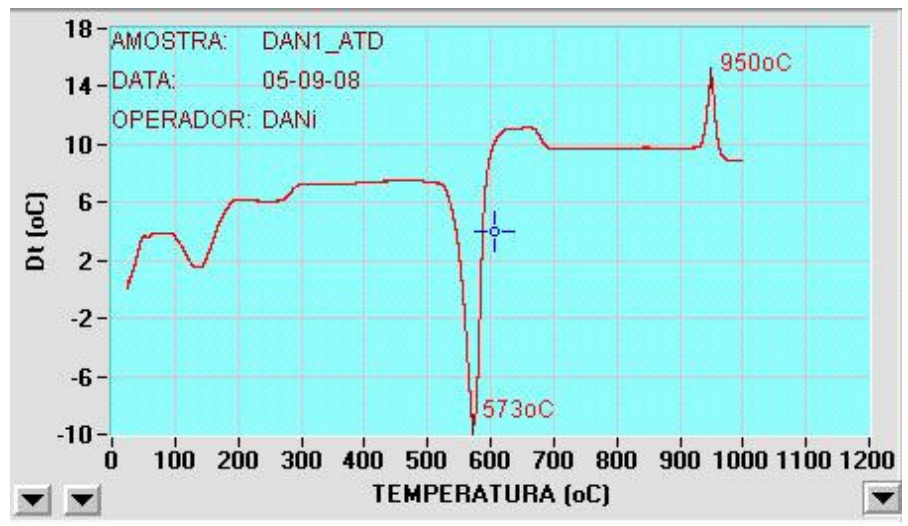

Figura 49. Resultado do ensaio ATD da amostra 1

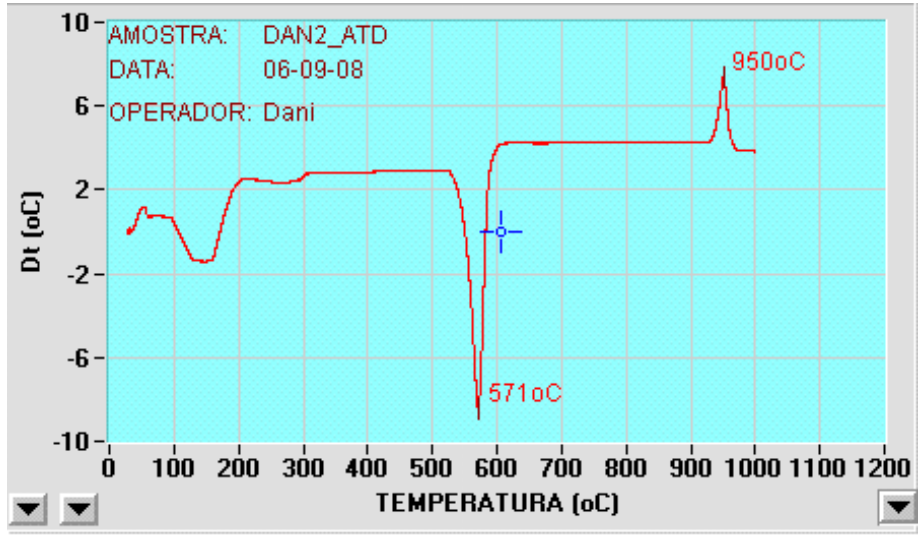

Figura 50. Resultado do ensaio ATD da amostra 2 


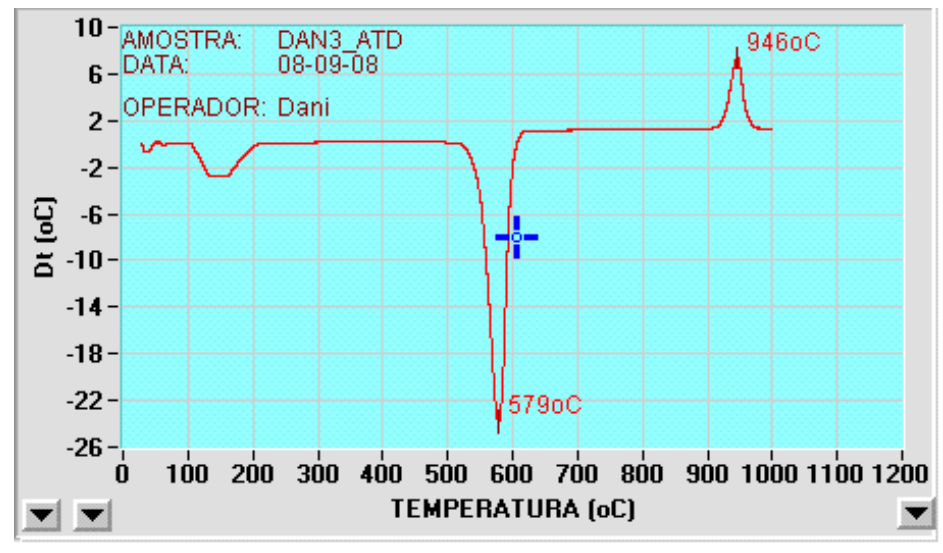

Figura 51. Resultado do ensaio ATD da amostra 3

Em relação aos ensaios ATG, os resultados obtidos não permitiram confirmar os resultados dos ensaios ATD. Tal fato pode ter ocorrido devido à presença de contaminantes no solo local. A Figura 52 mostra um gráfico característico obtido para o ensaio ATD de uma das amostras ensaiadas.

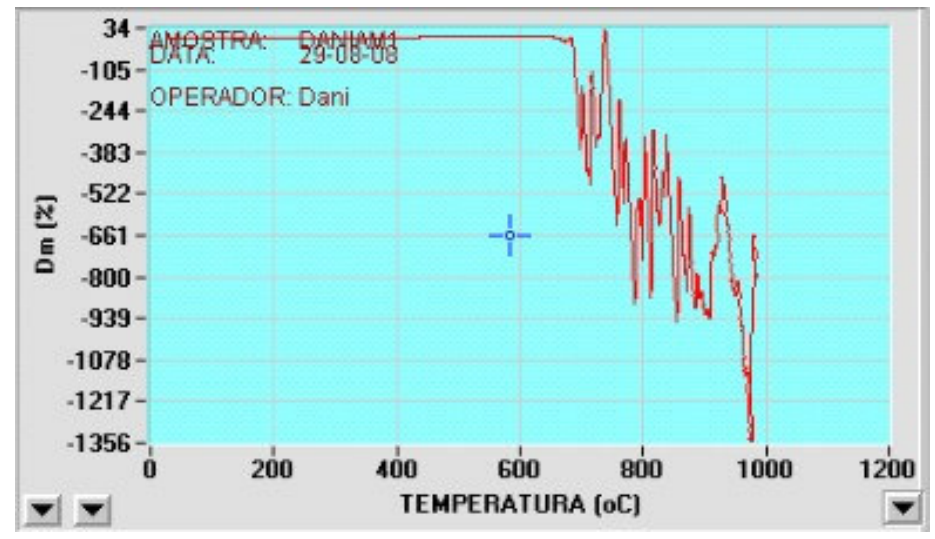

Figura 52. Resultado característico do ensaio ATG para uma das amostras estudadas

\section{$5.1 .6-\Delta \mathrm{pH}$}

A Tabela 5 mostra os resultados de $\Delta \mathrm{pH}$ obtidos, todos com valores negativos, logo, há uma predominância de cargas negativas. No entanto, não se pode afirmar que estas sejam permanentes ou variáveis. Segundo Camapum de Carvalho et al. (2006) valores de $\mathrm{pH}$ em $\mathrm{KCl}$ menores indicam que há uma maior presença de argilominerais em detrimento de oxi-hidróxidos de ferro e alumínio, ou seja, o solo se encontra menos intemperizado. 
Tabela 5 - Valores de $\mathrm{pH}$ obtidos e resultados

\begin{tabular}{cccc}
\hline Amostra & $\mathrm{H} 2 \mathrm{O}$ & $\mathrm{KCl}$ & $\Delta \mathrm{pH}$ \\
\hline 1 & 5,34 & 4,04 & $-1,30$ \\
2 & 6,20 & 4,49 & $-1,71$ \\
3 & 5,37 & 4,17 & $-1,20$ \\
\hline
\end{tabular}

\subsection{7 - Curva característica}

Para uma melhor definição da curva de retenção das amostras estudadas, foram utilizados resultados do ensaio de funil de placa porosa em conjunto com o de papel filtro. Assim, determinou-se a curva característica, com o auxílio do software RETC desenvolvido pelo Laboratório de Salinidade dos Estados Unidos, representada como uma linha tracejada na Figura 53 a Figura 55.

A distribuição, obtida através dos ensaios, apresenta duas pressões de entrada de ar, representadas pelos pontos de inflexão da curva de retenção. Esse tipo de curva é chamado de bimodal, sendo a primeira parte (umidades mais altas) caracterizada pelos macroporos, formados pelos vazios entre agregados e/ou grãos maiores, e a segunda pelos microporos, formados no interior dos agregados, conforme descrito por Rodrigues (2007).

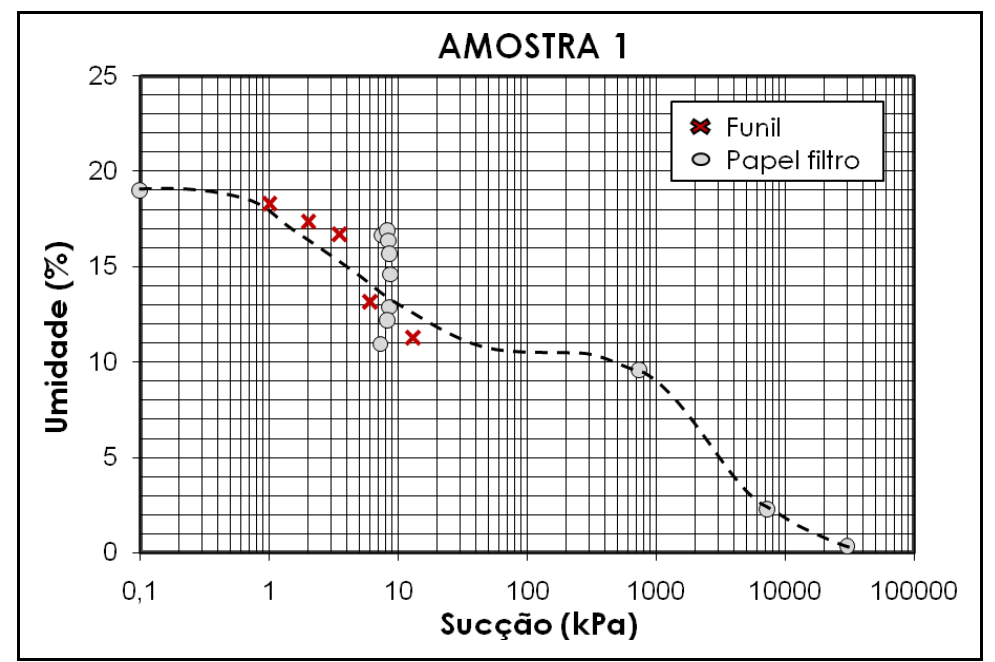

Figura 53. Curva característica da Amostra 1 


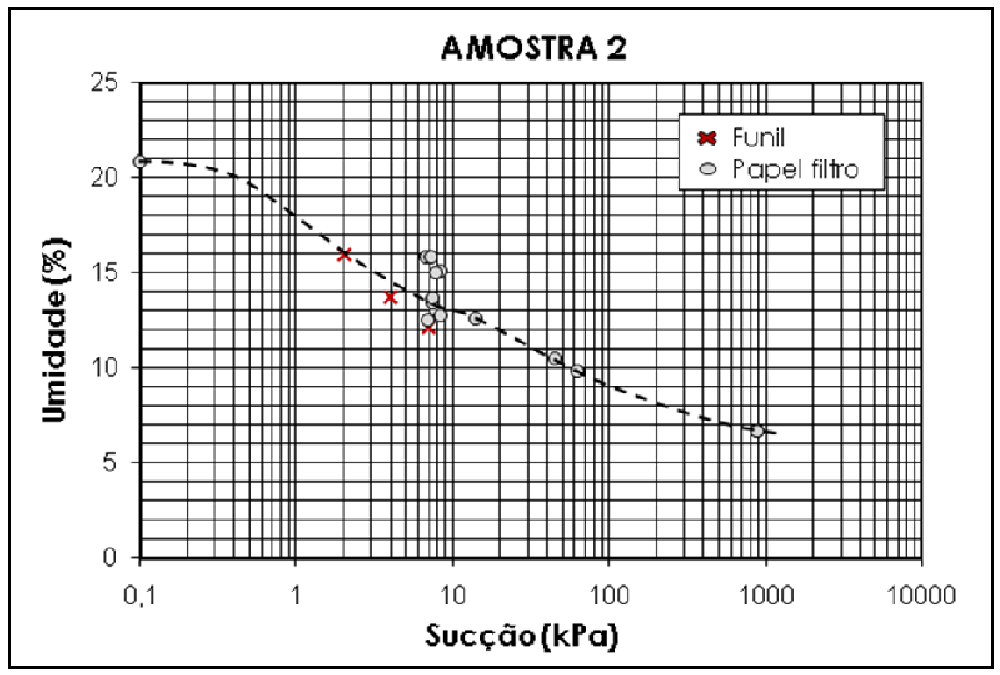

Figura 54. Curva característica da Amostra 2

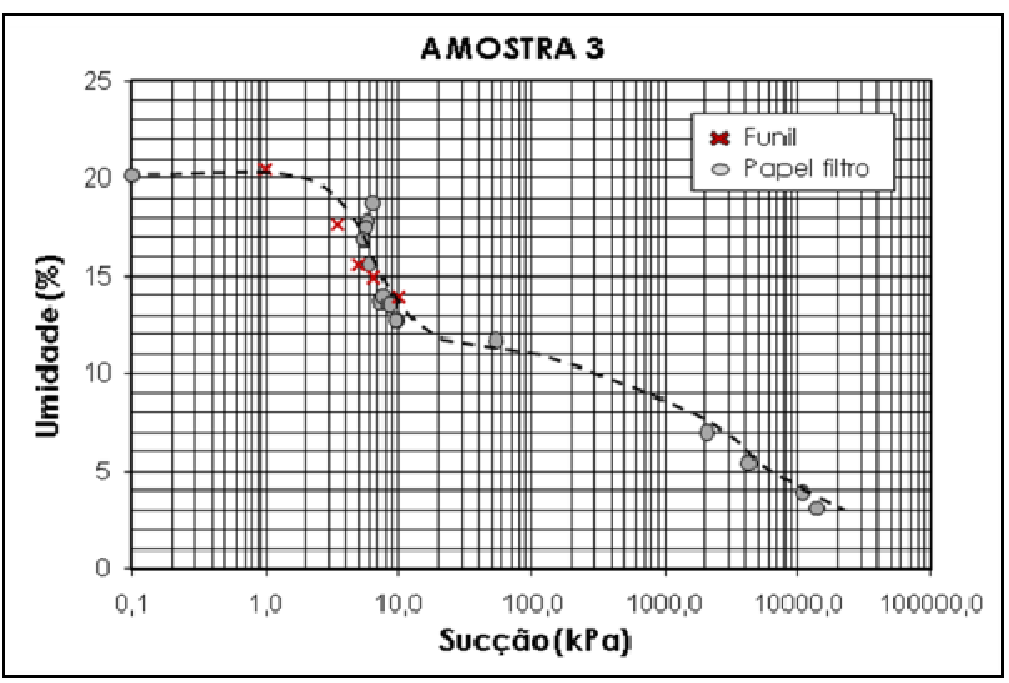

Figura 55. Curva característica da Amostra 3

\section{2 - Erodibilidade}

Entre os ensaios de erodibilidade, foram executados aqueles que seguem as metodologias de: Inderbitzen (1961) como ensaio de mesmo nome, de Nogami \& Villibor (1979) com o ensaio de absorção de água e de Alcântara \& Vilar (1998) com o ensaio de penetração de cone, cujos resultados são apresentados a seguir. 


\subsection{1 - Inderbitzen}

Na Figura 56 a Figura 58 encontram-se os resultados com escoamento laminar (a) e com a ação da gota (b), realizados separadamente. Cada amostra foi ensaiada em 3 inclinações diferentes $\left(15^{\circ}, 31^{\circ}\right.$ e $\left.50^{\circ}\right)$. Os gráficos estão expressos em termos da perda de solo acumulada $\left(\mathrm{g} / \mathrm{cm}^{2}\right)$ por tempo (minutos). Verifica-se a tendência de estabilização das perdas de solo em cerca de 10 minutos de ensaio, que está de acordo com os resultados apresentados por Pereira et al. (2003, apud Mendes, 2006).

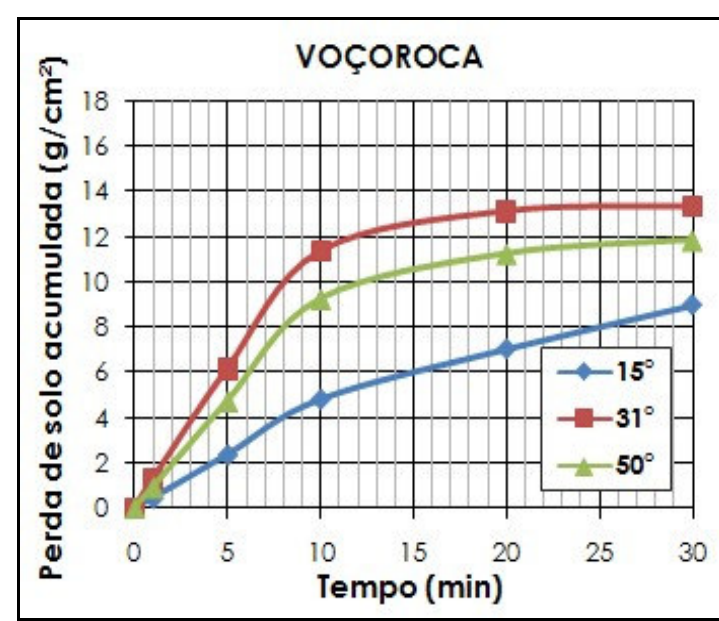

a) escoamento laminar

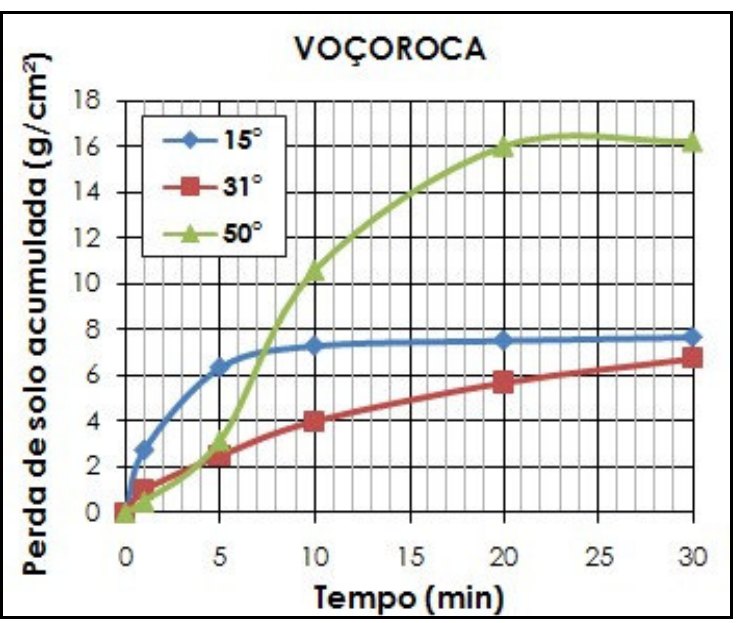

b) gota

Figura 56. Resultados do ensaio Inderbitzen para a amostra 1

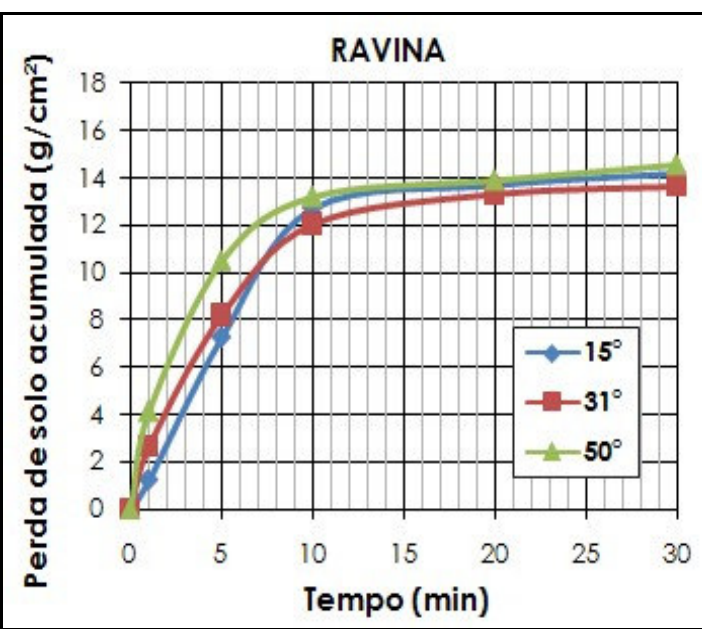

a) escoamento laminar

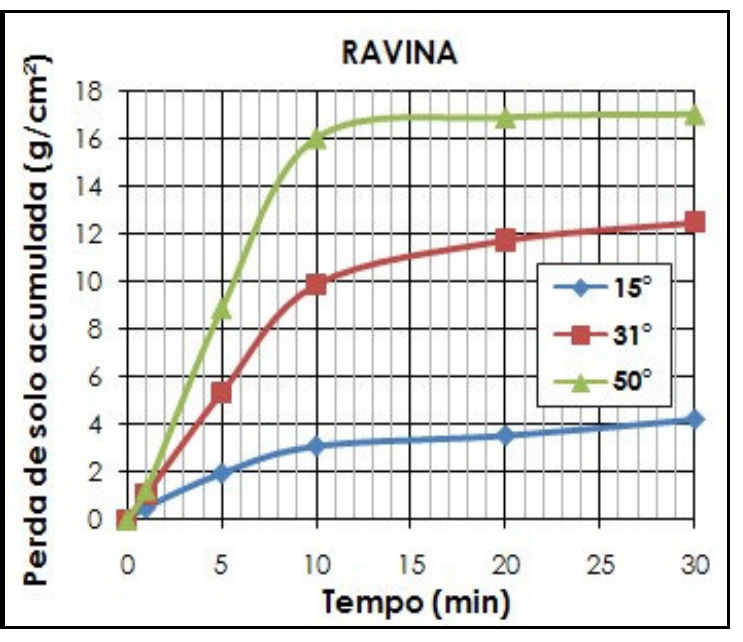

b) gota

Figura 57. Resultados do ensaio Inderbitzen para a amostra 2 


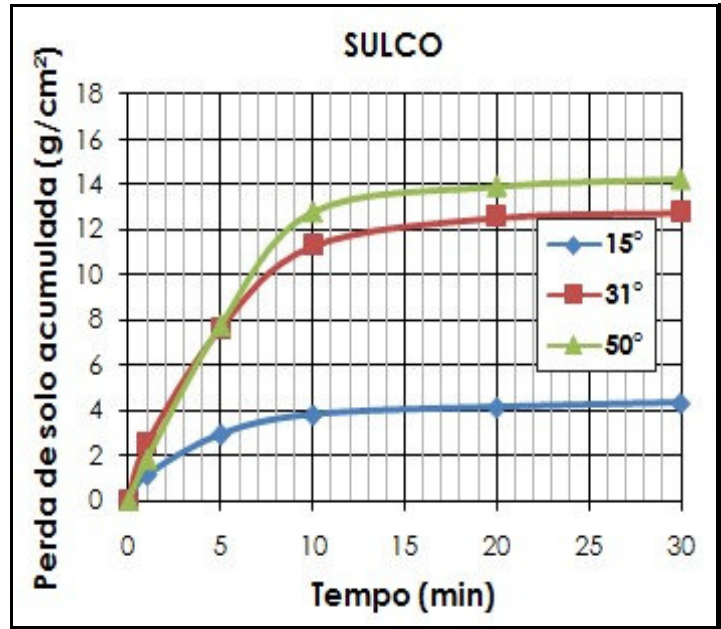

a) escoamento laminar

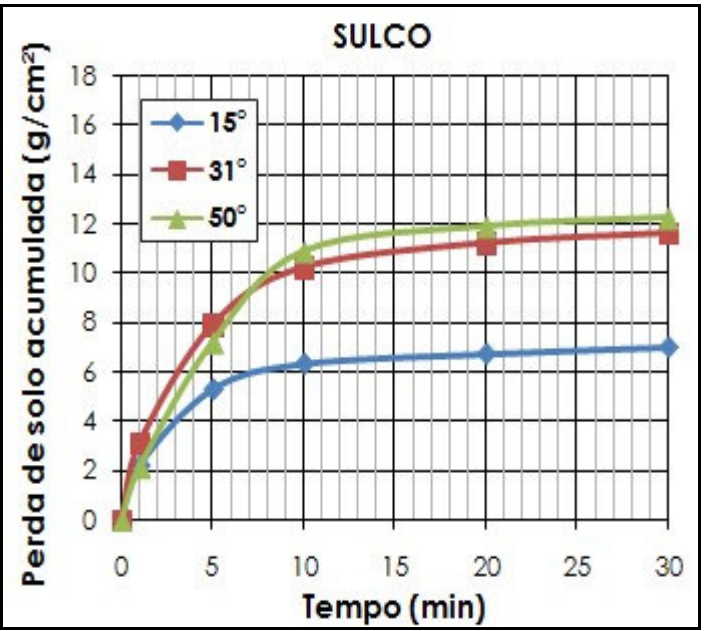

b) gota

Figura 58. Resultados do ensaio Inderbitzen para a amostra 3

Observa-se que não foi possível determinar um comportamento padrão de perda de solo, apesar de todos possuírem a mesma textura. Os resultados obtidos com as três peneiras (\#50, \#100 e \#200) com cada inclinação encontram-se no APÊNDICE A. Também não é possível determinar um padrão de perda de solo com o aumento da inclinação da rampa. Pode-se verificar uma tendência ao aumento da perda de areia média conforme cresce a inclinação da rampa, tanto para o escoamento laminar, quanto para a ação da gota na amostra de solo. Entretanto, esses resultados devem ser considerados como parciais, pois não foi possível verificar a repetibilidade desse ensaio, especialmente devido a heterogeneidade das amostras.

\subsection{2 - Absorção de água e perda por imersão}

A erodibilidade também foi avaliada empregando-se a metodologia MCT, proposta por Nogami \& Villibor (1979), com o ensaio de absorção de água e perda por imersão. A partir do gráfico de absorção de água pelo tempo, determinou-se o coeficiente angular da curva de absorção (S) de cada corpo-de-prova, como na Figura 59. Os valores dos coeficientes obtidos foram então relacionados com a perda imersão dos mesmos corpos- 
de-prova após a absorção da água. Na Tabela 6 estão apresentados os resultados de vários corpos-de-prova de cada amostra de solo estudada.

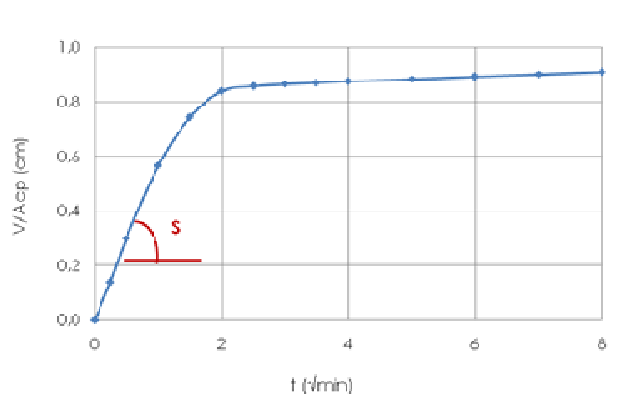

Figura 59. Resultado típico da curva de absorção de água para determinação do coeficiente angular

Tabela 6 - Resultados dos ensaios de absorção para cada amostra ensaiada

\begin{tabular}{|c|c|c|}
\hline Amostra & $\begin{array}{c}S \\
(\mathrm{~cm} / \sqrt{\min })\end{array}$ & $\begin{array}{c}\mathrm{Pi} \\
(\%)\end{array}$ \\
\hline \multirow{9}{*}{1} & 0,548 & 39,3 \\
\hline & 0,227 & 46,3 \\
\hline & 0,167 & 31,3 \\
\hline & 0,370 & 28,6 \\
\hline & 0,880 & 42,0 \\
\hline & 0,630 & 35,7 \\
\hline & 0,830 & 36,2 \\
\hline & 0,930 & 41,7 \\
\hline & 0,729 & 37,9 \\
\hline \multirow{10}{*}{2} & 0,310 & 51,1 \\
\hline & 0,252 & 47,7 \\
\hline & 0,314 & 47,7 \\
\hline & 0,306 & 47,1 \\
\hline & 0,672 & 37,0 \\
\hline & 1,292 & 40,7 \\
\hline & 0,234 & 21,9 \\
\hline & 0,520 & 44,2 \\
\hline & 1,200 & 14,2 \\
\hline & 1,090 & 38,3 \\
\hline \multirow{10}{*}{3} & 0,113 & 40,2 \\
\hline & 0,183 & 42,2 \\
\hline & 0,239 & 38,9 \\
\hline & 0,169 & 44,5 \\
\hline & 0,104 & 16,7 \\
\hline & 0,118 & 31,6 \\
\hline & 0,140 & 28,7 \\
\hline & 0,140 & 30,3 \\
\hline & 0,170 & 23,7 \\
\hline & 0,130 & 33,9 \\
\hline
\end{tabular}




\subsection{3 - Penetração de cone}

Os resultados do ensaio de penetração de cone, sugeridos por Alcântara e Vilar (1998), são apresentados na Tabela 7. Para as amostras 1 e 3, nitidamente heterogêneas, os limites de leitura mínima e máxima de $\pm 5 \%$ da leitura média não foram considerados, pois descartavam uma grande quantidade de dados. Neste ensaio, alguns corpos-de-prova ensaiados apresentaram resultados distintos dos outros ensaios realizados para avaliar a erodibilidade dos solos estudados. Isso ocorre porque alguns valores de DP obtidos foram menores que DPlimite e, portanto, classificaram o solo como de baixa erodibilidade.

\begin{tabular}{|c|c|c|c|}
\hline Amostra & $\begin{array}{l}\mathrm{DP} \\
(\%)\end{array}$ & $\begin{array}{l}\text { Pnat } \\
\text { (mm) }\end{array}$ & $\begin{array}{c}P_{\text {limite }} \\
(\%)\end{array}$ \\
\hline \multirow{3}{*}{1} & 38,35 & 11,19 & 50,36 \\
\hline & 30,70 & 5,36 & 24,10 \\
\hline & 35,92 & 10,20 & 45,90 \\
\hline \multirow{3}{*}{2} & 59,59 & 5,49 & 24,70 \\
\hline & 35,90 & 5,36 & 24,12 \\
\hline & 5,21 & 6,19 & 27,83 \\
\hline \multirow{3}{*}{3} & 16,10 & 6,13 & 27,59 \\
\hline & 42,99 & 3,38 & 15,21 \\
\hline & 56,10 & 4,16 & 18,72 \\
\hline
\end{tabular}

\section{3 - Parâmetros mecânicos}

Ensaios de compressão edométrica na condição de umidade natural e inundada foram realizados para avaliar o histórico de tensões dos solos estudados. As tensões de préadensamento $\left(\sigma^{\prime}\right.$ ad) foram determinadas através do método de Pacheco e Silva e são apresentados na Tabela 8. Comparando-se os valores das tensões de pré-adensamento na condição natural e inundada, observou-se que a tensão de pré-adensamento ( $\sigma^{\prime}$ ad $)$ na condição natural foi sempre maior que na condição saturada, conforme ilustrado na Figura 60. Dessa forma, o aumento da umidade do solo provoca uma redução na contribuição da sucção matricial no pré-adensamento desse solo. 
Tabela 8 - Tensão de pré-adensamento para as amostras nos estados natural e inundado

\begin{tabular}{ccc}
\hline Amostra & Característica & $\begin{array}{c}\sigma^{\prime} \text { ad } \\
(\mathrm{kPa})\end{array}$ \\
\hline \multirow{2}{*}{1} & Natural & 32,0 \\
& Inundada & 17,0 \\
\hline \multirow{2}{*}{2} & Natural & 28,0 \\
& Inundada & 5,5 \\
\hline \multirow{2}{*}{3} & Natural & 30,5 \\
& Inundada & 21,0 \\
\hline
\end{tabular}

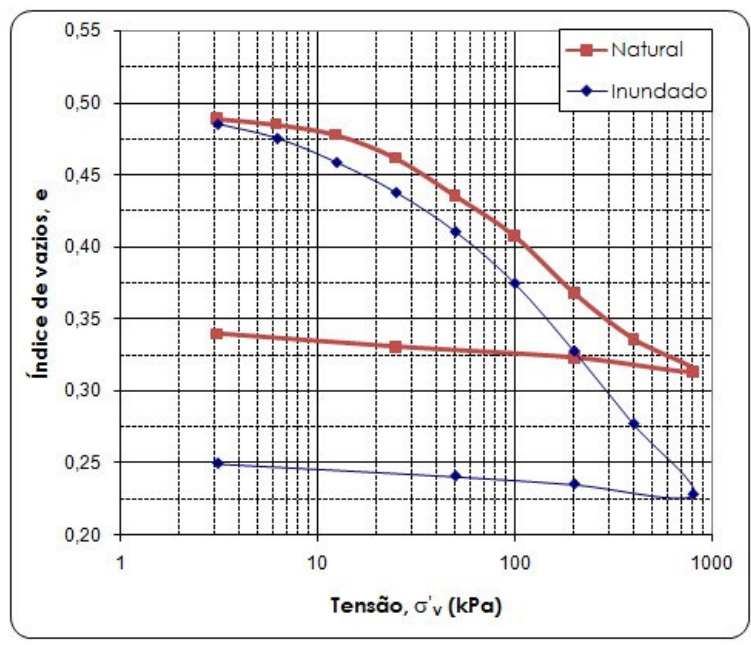

Figura 60. Resultado típico da curva compressão edométrica na condição natural e inundada (Am. 3)

O resultado dos ensaios de compressão edométrica indica que os ensaios de cisalhamento direto foram conduzidos para a condição normalmente adensada, pois as tensões de pré-adensamento só são maiores na primeira das quatro tensões verticais empregadas nos ensaios de cisalhamento direto realizados. Ensaios triaxiais foram selecionados inicialmente para determinação das propriedades do solo, porém, em algumas amostras coletadas não foi possível talhar os corpos-de-prova cilíndricos, porque o solo era muito arenoso. Por isso, os ensaios de cisalhamento direto foram realizados para esse fim.

Foram realizados ensaios de cisalhamento direto com a amostra natural e inundada. A velocidade máxima a ser utilizada em um ensaio drenado, ou seja, para que não haja excesso de poro-pressão na fase de ruptura, pode ser estimada a partir de resultado de um ensaio de compressão edométrica, conforme sugere Gibson \& Henkal (1954, apud Head, 1982), pela equação 6. 


$$
t_{f}=12,7 \times t_{100}
$$

Na qual: $\dagger_{100}=$ tempo para que ocorra $100 \%$ do adensamento primário;

$t_{f}=$ tempo para que ocorra a ruptura.

Assim, a velocidade máxima de ensaio foi definida determinando-se o valor de $t_{100}$ a partir do estágio de tensão vertical de $100 \mathrm{kPa}$ do ensaio de compressão edométrica realizado na amostra 3, apresentada na Figura 61. Assim sendo, com tioo foi igual a 0,203 minutos, tem-se:

$$
t_{f}=12,7 \times 0,203=2,57 \text { minutos }
$$

A velocidade máxima de ensaio (Head, 1982) para que não se gere poro-pressão é dada por:

$$
\mathrm{V}_{\text {máx }}=\frac{\varepsilon_{f} \times L}{100 \times t_{f}}
$$

Na qual: $L$ = tamanho do corpo-de-prova $(\mathrm{mm})$;

$\varepsilon_{f}=$ deformação na ruptura (\%);

$t_{f}=$ tempo para que ocorra a ruptura (min).

Para as dimensões do corpo de prova ensaiado e assumindo que a deformação máxima na ruptura (£f) estimada é de $10 \%$ tem-se:

$$
\mathrm{V}_{\text {máx }}=\frac{10 \times 60}{100 \times 2,57}=2,3 \mathrm{~mm} / \mathrm{min}
$$

Nos ensaios de cisalhamento direto realizados a velocidade de ensaio utilizada foi de 0,30 mm/min, muito inferior a máxima permitida para que não se gerasse poro-pressão, para possibilitar as leituras visualmente por um único operador. Assim, esses ensaios podem ser considerados do tipo lento e os parâmetros de resistência determinados são em termos de tensões efetivas.

As curvas típicas de tensão de cisalhamento e deformação vertical por deslocamento horizontal são apresentadas na Figura 62. Cada curva corresponde a uma tensão vertical (em kPa) a qual o corpo-de-prova foi submetido, como pode ser observado 
na legenda. As envoltórias de resistência estão apresentadas na Figura 63 a Figura 65 , respectivamente para as amostras 1, 2 e 3.

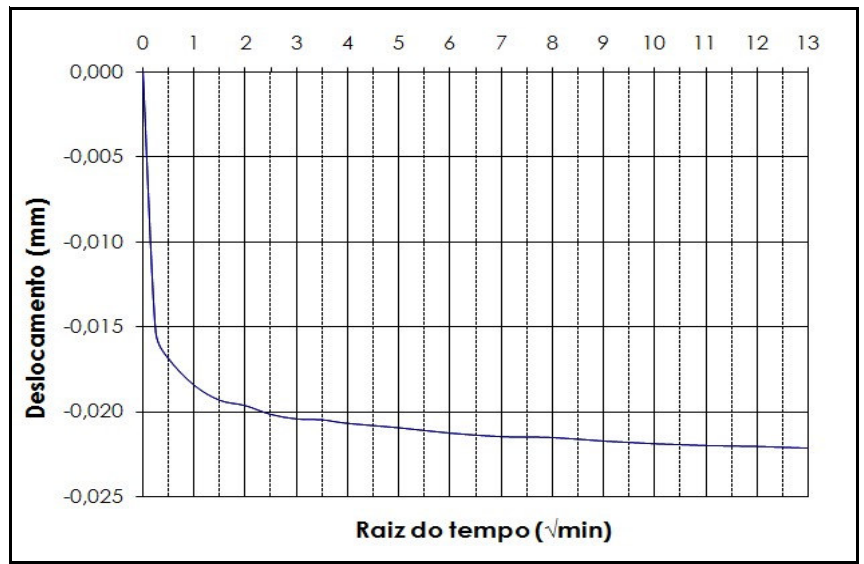

Figura 61. Determinação do tempo para ocorrer $100 \%$ do adensamento primário ( $\left.\dagger_{100}\right)$ com base no resultado do ensaio de compressão edométrica da amostra 3 para tensão vertical de $100 \mathrm{kPa}$.
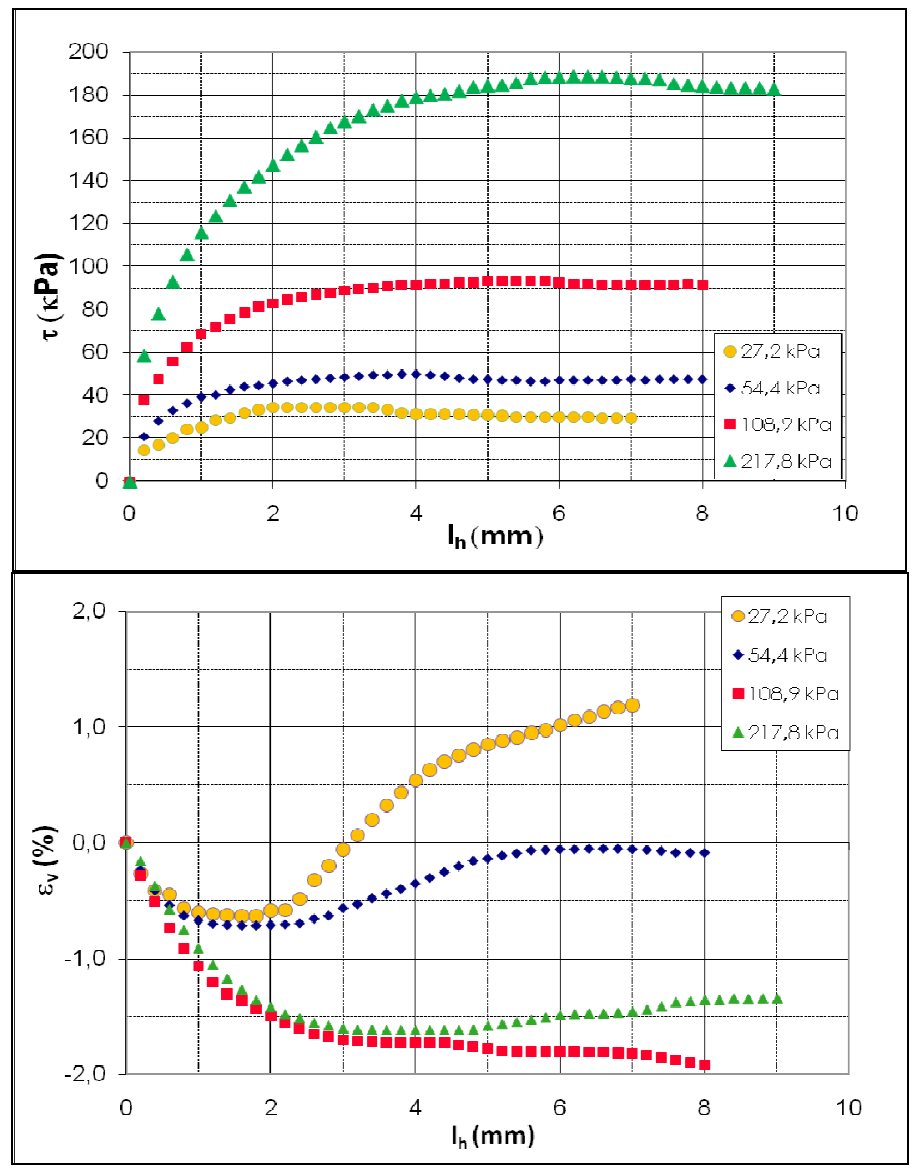

Figura 62. Curvas típicas do ensaio de cisalhamento realizado em uma das amostras ensaiadas 


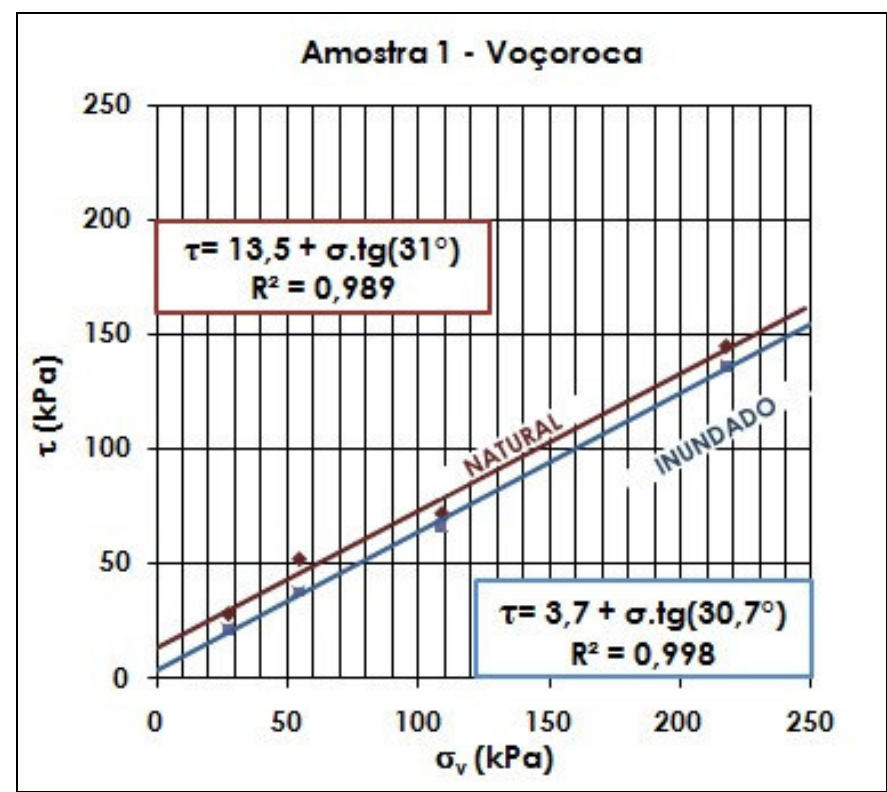

Figura 63. Envoltória de resistência e respectivos parâmetros de resistência para a amostra 1 na condição natural e inundada

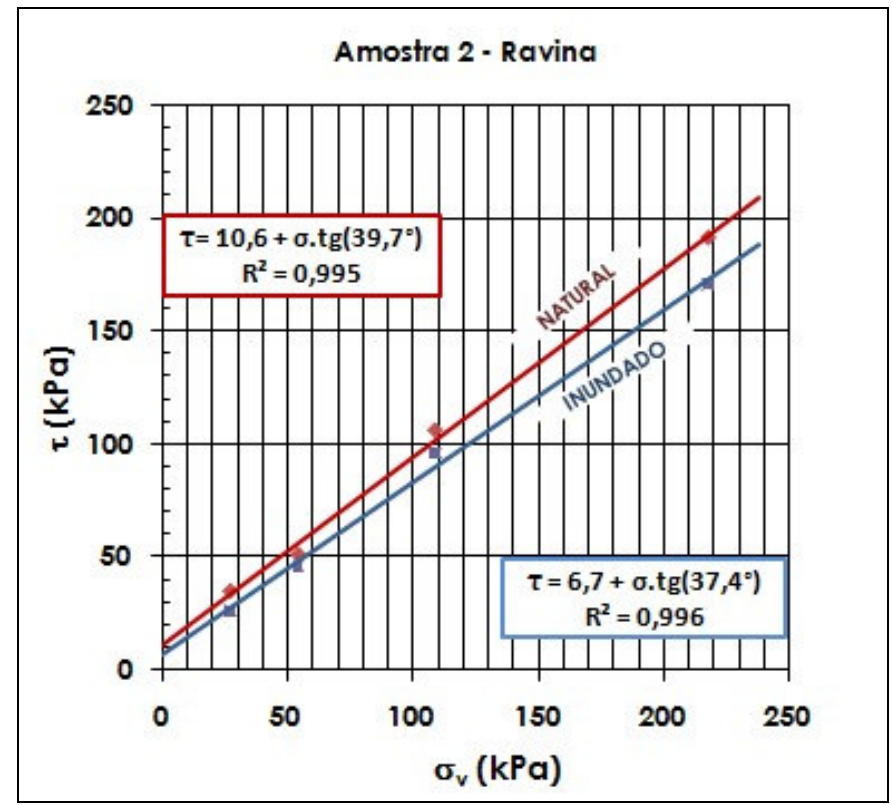

Figura 64. Envoltória de resistência e respectivos parâmetros de resistência para a amostra 2 na condição natural e inundada 


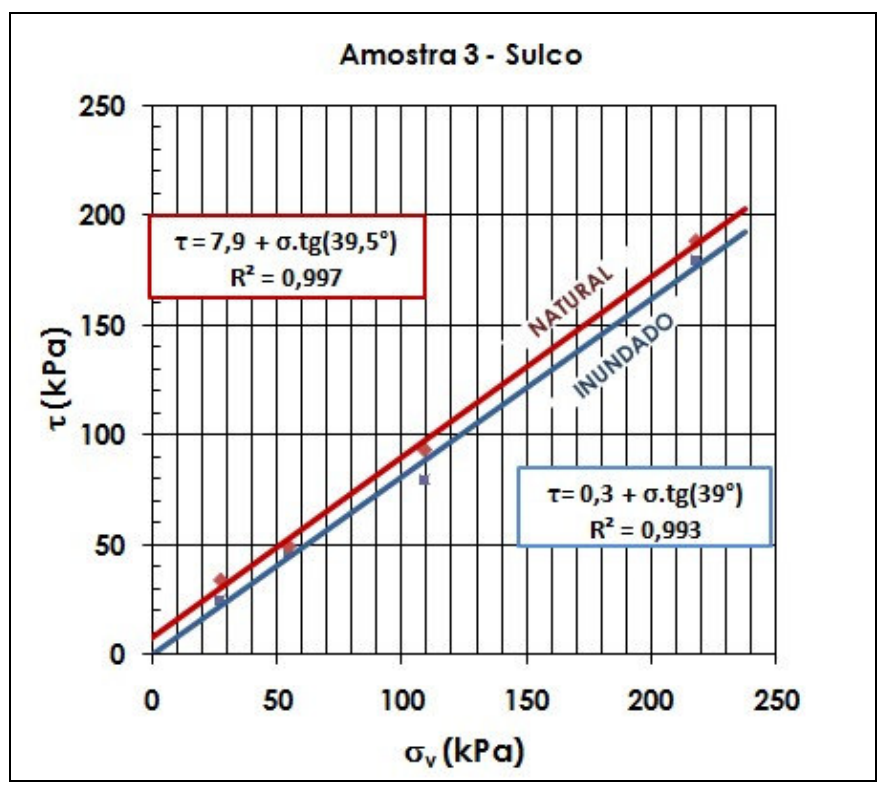

Figura 65. Envoltória de resistência e respectivos parâmetros de resistência para a amostra 3 na condição natural e inundada

Os resultados dos ensaios realizados nas amostras naturais e inundadas indicaram a diminuição do intercepto de coesão com a ação da água sem mudanças consideráveis do ângulo de atrito (Tabela 9). Esse comportamento é característico para solos arenosos.

Tabela 9 - Parâmetros de resistência para as três amostras ensaiadas na condição natural e inundada

\begin{tabular}{cccc}
\hline Amostra & Característica & $\begin{array}{c}\text { Coesão } \\
(\mathrm{kPa})\end{array}$ & $\begin{array}{c}\text { Ângulo de atrito } \\
\left({ }^{\circ}\right)\end{array}$ \\
\hline \multirow{2}{*}{1} & Natural & 12,6 & 31,3 \\
& Inundada & 2,5 & 30,7 \\
\multirow{2}{*}{2} & Natural & 10,6 & 39,8 \\
& Inundada & 6,6 & 37,4 \\
\hline \multirow{2}{*}{3} & Natural & 7,8 & 39,5 \\
& Inundada & 0,3 & 39,0 \\
\hline
\end{tabular}

\section{4 - Ensaios e observações de campo}

As sondagens de simples reconhecimento com medida do SPT foram realizadas na borda do talude do processo erosivo, dispostos de forma a definir o perfil estratigráfico. Ensaios transversais à borda do talude foram realizados a fim de avaliar a influência do fluxo 
de água no talude longitudinalmente e transversalmente. A localização desses ensaios está representada na Figura 35.

\subsection{1 - Sondagem de simples reconhecimento}

Na Figura 66 é apresentado o resultado de uma das sondagens de simples reconhecimento com medida de SPT realizada na área, representativa de todas as demais. Observa-se, nessa figura, que o perfil de solo é arenoso, mas com presença de camadas mais argilosas. Nessa sondagem, o nível d'água foi encontrado a cerca de 3,5m de profundidade. Os valores de NSPT indicam um ressecamento nos primeiros metros (NSPT igual a 11, no primeiro, e 8 , no segundo metro) e depois este diminui para valores entre 2 e 8 a profundidades entre 3 e $9 \mathrm{~m}$. A partir de $10 \mathrm{~m}$ de profundidade, o Nspt aumenta entre 16 e 42 , atingindo o impenetrável do SPT aos 13m de profundidade.

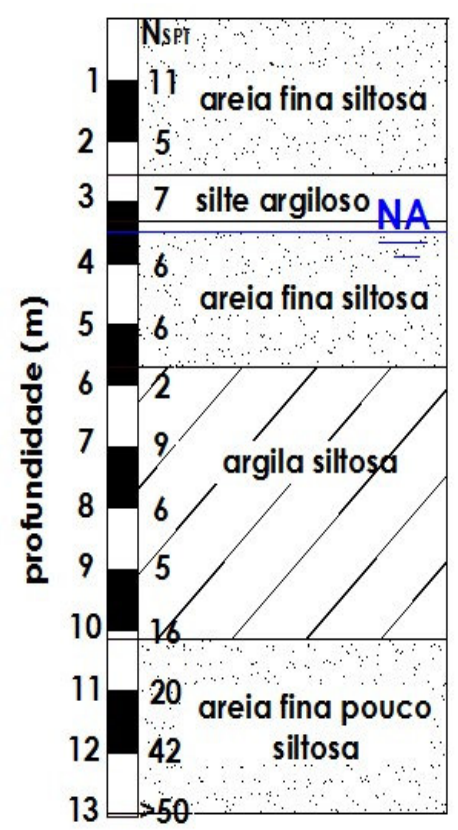

Figura 66. Resultado obtido da sondagem 2 


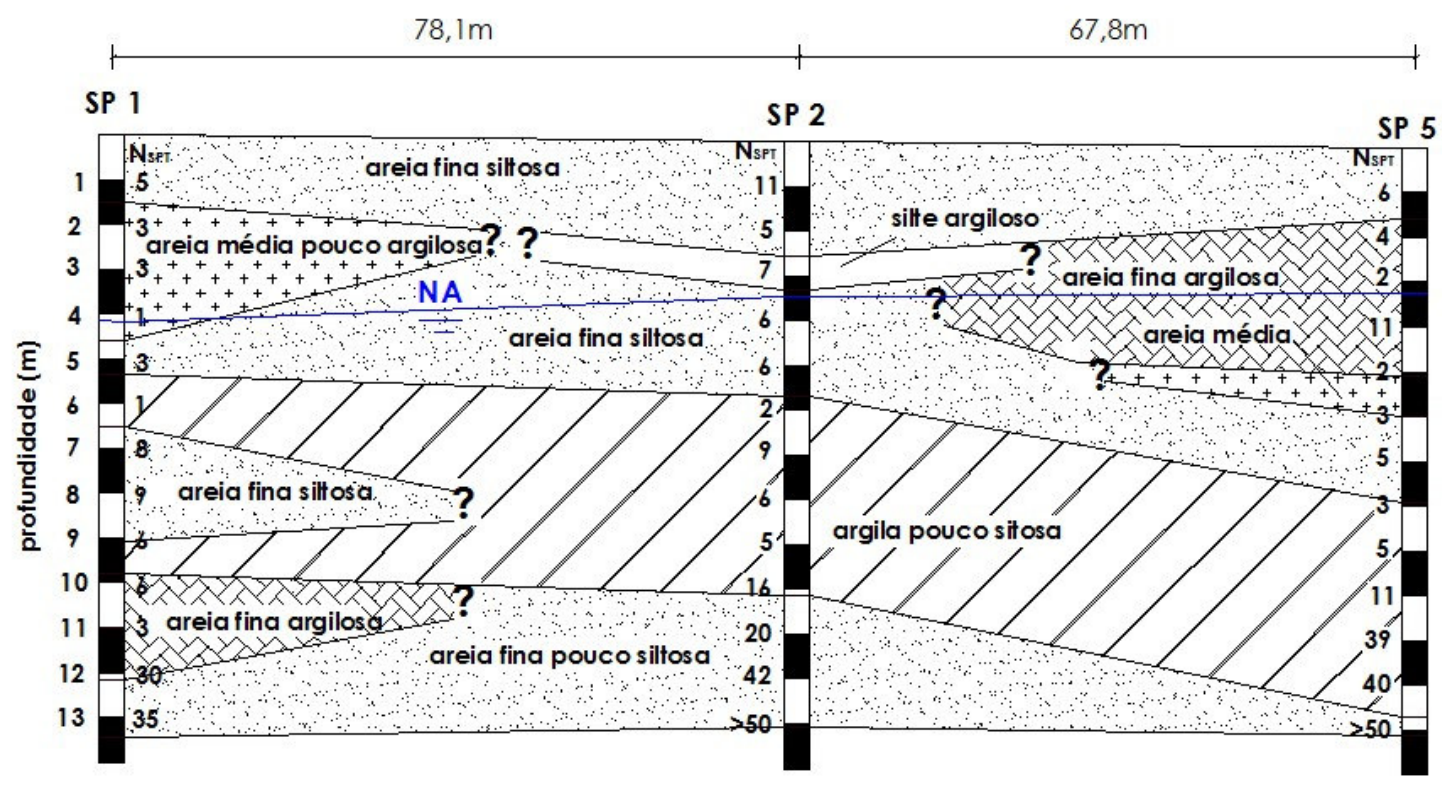

Figura 67. Perfil longitudinal interpretado a partir do resultado das sondagens 1, 2 e 5.

A variabilidade do solo pode ser observada no perfil longitudinal interpretado a partir de sondagens de simples reconhecimento (Figura 67). Tal variação pode ser notada também na Figura 68, que possibilita analisar a variabilidade de cor do solo com a profundidade. A presença de maiores quantidades de óxido de ferro é observada nas amostras com coloração avermelhada. Na superfície de todos os furos de sondagem, foi verificada coloração escura, proveniente de matéria orgânica.

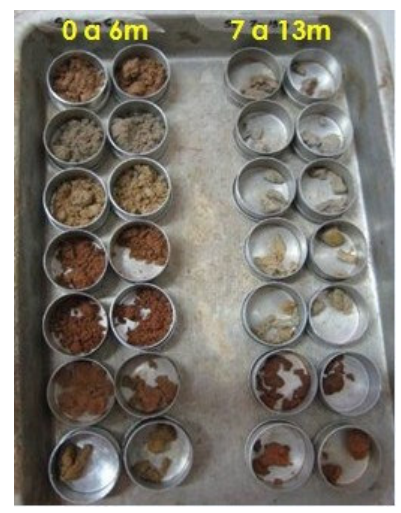

Figura 68. Amostras de solos em cápsulas de umidade coletadas na sondagem 1 


\subsection{3 - Observação da evolução do processo erosivo no campo}

O avanço do processo erosivo no tempo foi avaliado realizando levantamentos topográficos em dois locais previamente selecionados em função do que se observou na área. No local 2, no qual há um processo de ravinamento, a evolução não foi nítida, tanto nas observações de campo, como no monitoramento topográfico. Por isso, o avanço nesse local não será apresentado.

No local 1, no qual há um talude de voçoroca, observou-se que a evolução por escorregamento ocorre nos locais onde há uma concentração do fluxo de água superficial (Figura 69).

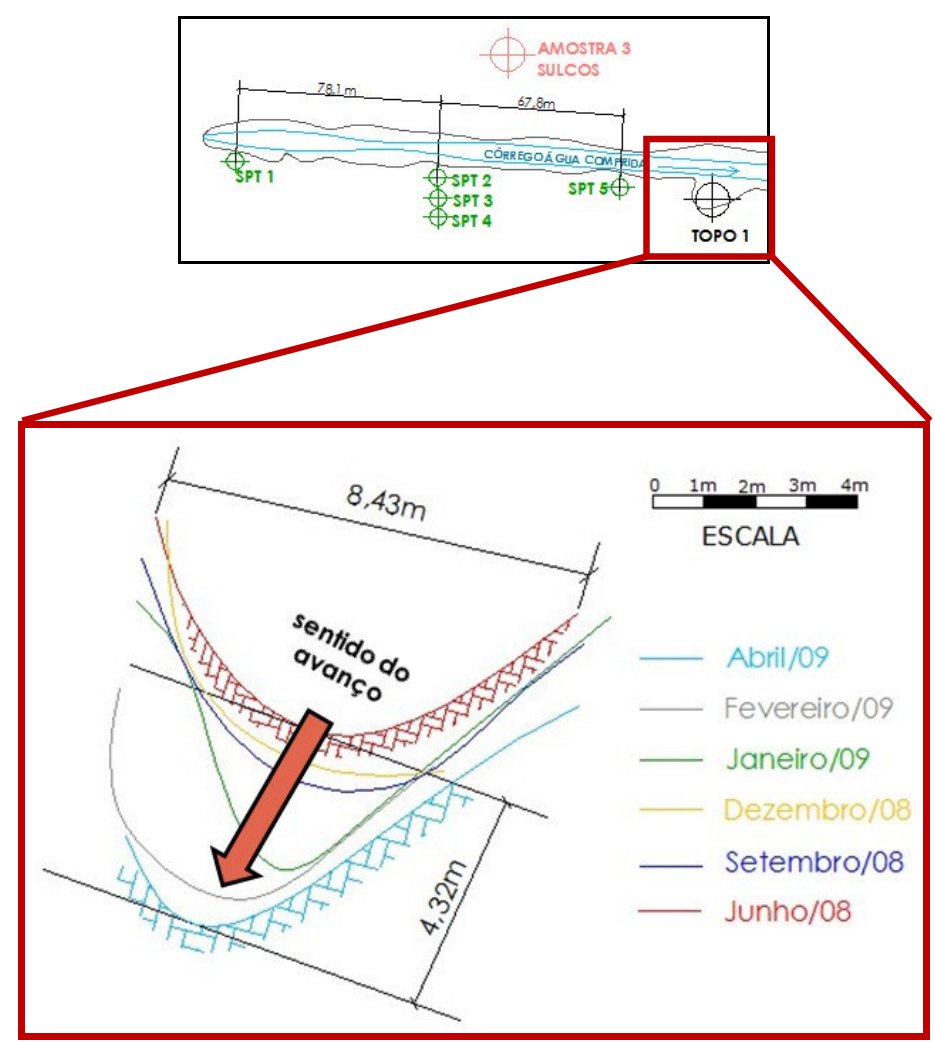

Figura 69. Representação esquemática da evolução do processo erosivo no local 1 da área estudada

Pode-se observar que houve um avanço de cerca de 4,3m entre os meses de junho e abril de 2009 e que este avanço não é linear. A evolução não foi representada em todos os meses que foram feitas medidas, pois alguns não apresentaram avanços significativos das bordas do talude. 
Na observação de campo realizadas nas várias excursões realizadas na área foi possível verificar trincas de retração paralelas às bordas dos taludes, as quais são caminhos preferenciais de entrada de água, que desencadeiam os escorregamentos sucessivos em fatias (Figura 70).

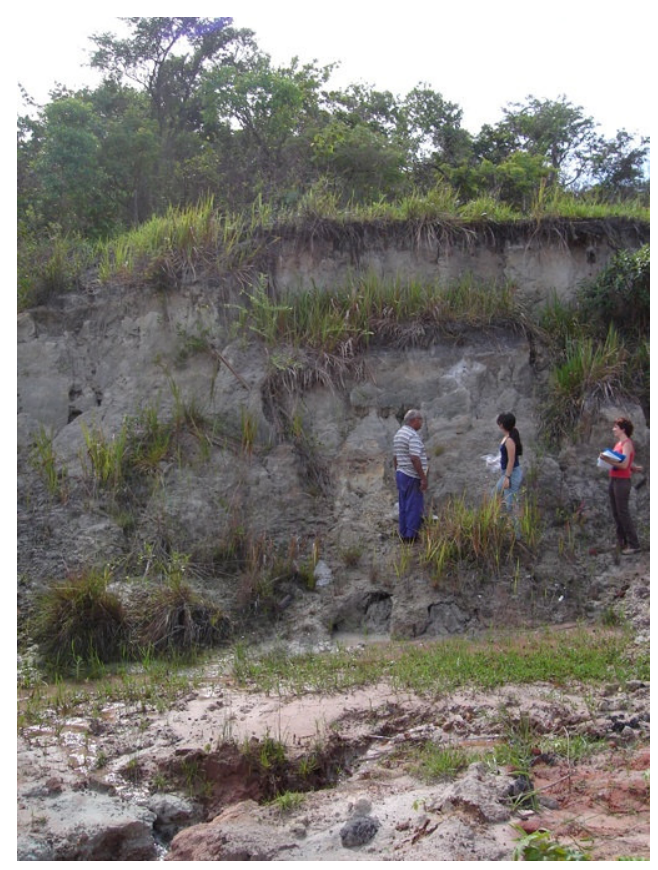

Figura 70. Escorregamentos sucessivos observados em campo

Com a retirada do material da base, ocorrem quedas de blocos e escorregamentos. Em alguns casos, com a cimentação superficial (como observado nos ensaios SPT) e a vegetação, é formada uma camada muito resistente, em torno de $50 \mathrm{~mm}$, que não é removida inicialmente pelo fenômeno citado. Dessa maneira os taludes nesses locais são negativos no topo, como mostra a Figura 71. Entretanto, essa camada mais resistente é destruída quando ocorre um descalçamento da base. 


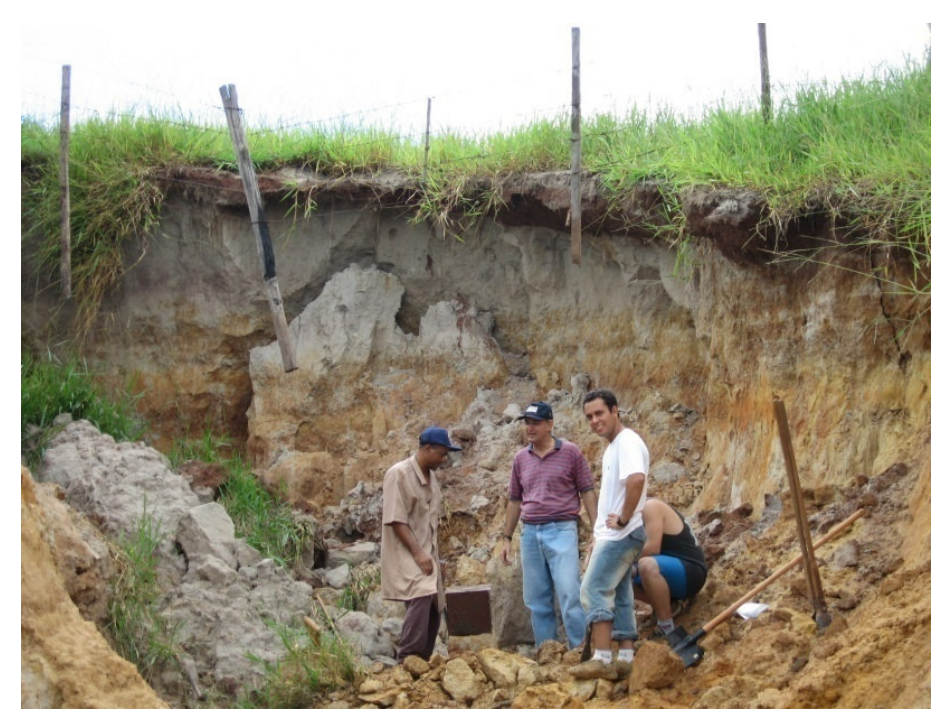

Figura 71. Superfície resistente do talude no seu topo

Nos trabalhos de campo, constatou-se que o avanço da voçoroca e da ravina estudadas se deu por escorregamento do solo dos taludes (Figura 72). Verifica-se ao lado da ravina (local de coleta da amostra 2 e levantamento topográfico 2) orifícios horizontais no talude causados pelo fenômeno de erosão interna retrogressiva, que carreia as partículas do interior do maciço (Figura 73).

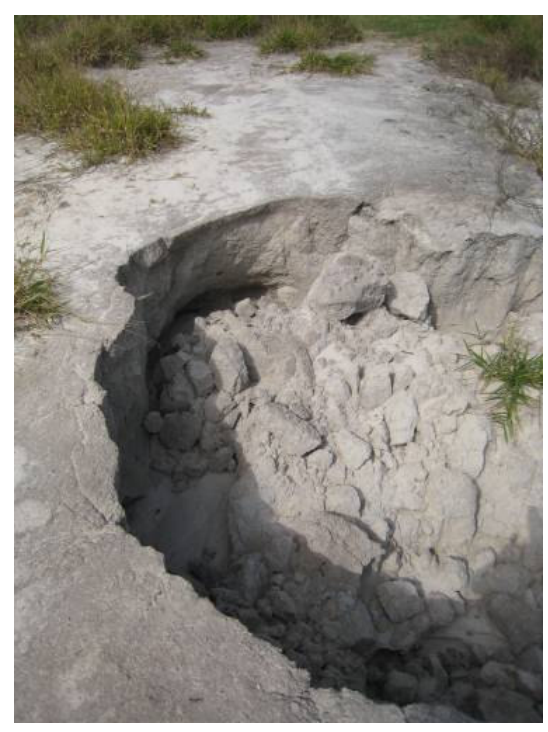

Figura 72. Solo escorregado no pé do talude no local de levantamento topográfico 2 


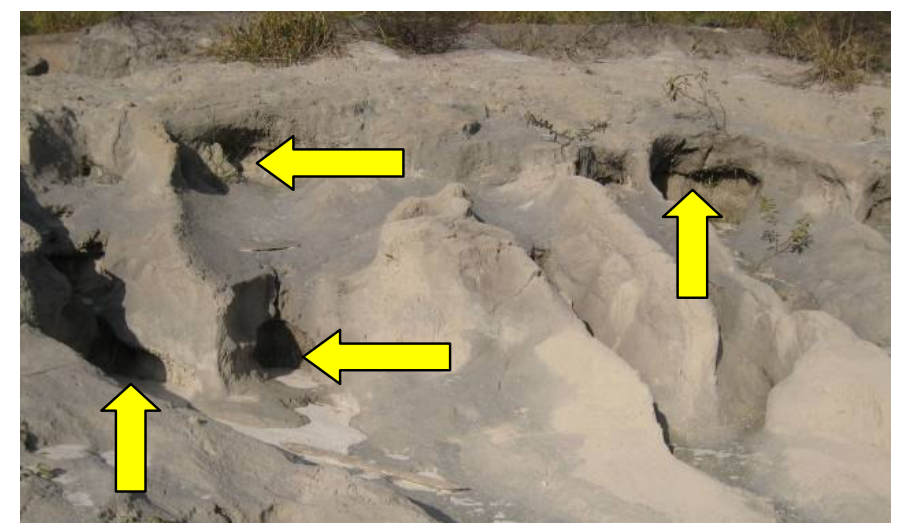

Figura 73. Formação de canais devido ao fenômeno de erosão interna retrogressiva 


\section{6 - ANÁLISE DOS RESULTADOS}

\section{1 - Caracterização}

\subsection{1 - Ensaios de campo}

O perfil de solo obtido através da sondagem SPT é característico de locais nos quais ocorre deposição de sedimentos com valores de Nspt baixos, com variação de textura e cor. Em geral, os perfis apresentam valores de Nspi entre 2 e 11 golpes até $12 \mathrm{~m}$ de profundidade. Após essa profundidade, os solos se tornam mais resistentes com Nspt aumentando para valores superiores a 50 golpes (Figura 66).

O solo predominante encontrado nas sondagens SPT é uma areia com pequena quantidade de finos (silte e/ou argila). Além dele, camadas de argila de até $5 \mathrm{~m}$ de espessura são verificadas no perfil. Os solos têm textura e cor que variam muito, ressaltando a ocorrência de deposição de sedimentos na área estudada.

$\mathrm{Na}$ Figura 67, tem-se representado o perfil longitudinal ao processo erosivo interpretado com base nos resultados de 3 ensaios SPT. Apesar da grande distância entre os furos tenta-se representar esse perfil, o que não foi tarefa fácil devido à dificuldade de representação dos horizontes de materiais que ocorrem no local, que possui grande variabilidade de solo. 


\subsection{2 - Ensaios de laboratório}

A partir das curvas granulométricas obtidas nos ensaios de granulometria conjunta, as amostras superficiais retiradas em 3 locais distintos e representativos do processo erosivo foram classificados texturalmente como areia argilosa com cores variando de vermelho a cinza claro. Segundo a classificação Unificada, essas amostras são do grupo SC e, na classificação HRB, são solos A-2-4. Na Tabela 10 estão apresentadas as porcentagens de cada fração no ensaio com e sem defloculante, esse último representado pela letra "s".

Tabela 10 - Classificação das amostras de solo estudadas

\begin{tabular}{ccccccc}
\hline \multirow{2}{*}{ Amostra } & \multicolumn{3}{c}{ Granulometria } & \multicolumn{3}{c}{ Classificação } \\
\cline { 2 - 7 } & $\begin{array}{c}\text { areia média } \\
(\%)\end{array}$ & $\begin{array}{c}\text { areia fina } \\
(\%)\end{array}$ & $\begin{array}{c}\text { silte } \\
(\%)\end{array}$ & $\begin{array}{c}\text { argila } \\
(\%)\end{array}$ & Unif. & HRB \\
\hline 1 & 50 & 38 & 5 & 7 & SC & A-2-4 \\
1 1s & 51 & 45 & 4 & 0 & & \\
2 & 46 & 41 & 6 & 7 & SC & A-2-4 \\
$2 \mathrm{~s}$ & 47 & 50 & 3 & 0 & & \\
3 & 45 & 36 & 8 & 11 & SC & A-2-4 \\
$3 \mathrm{~s}$ & 46 & 39 & 15 & 0 & & \\
\hline
\end{tabular}

A inexistência da fração de argila nos ensaios sem defloculante indica que, no campo, os argilominerais se agregam formando grumos ou agregando-se a partículas de solo, formando grãos maiores de textura variada (Figura 46 a Figura 48).

Na condição natural, tais amostras possuem os índices físicos apresentados na Tabela 11. O índice de vazios varia de $0,514<e<0,614$ e os vazios do solo não estão totalmente preenchidos por água $(57,2 \%<S r<63,5 \%)$, havendo assim a presença de fase gasosa com alguma sucção no solo.

Tabela 11 - Índices físicos do solo

\begin{tabular}{ccccccc}
\hline \multirow{2}{*}{ Am. } & $\begin{array}{c}\rho \\
(\mathrm{g} / \mathrm{cm} 3)\end{array}$ & $\begin{array}{c}\mathrm{W} \\
(\%)\end{array}$ & $\begin{array}{c}\mathrm{\rho s} \\
(\mathrm{g} / \mathrm{cm} 3)\end{array}$ & $\mathrm{e}$ & $\begin{array}{c}\mathrm{n} \\
(\%)\end{array}$ & $\begin{array}{c}\mathrm{Sr} \\
(\%)\end{array}$ \\
\hline 1 & 1,911 & 14,3 & 2,694 & 0,614 & 38,0 & 63,5 \\
2 & 2,021 & 13,8 & 2,688 & 0,514 & 34,0 & 72,4 \\
3 & 1,922 & 12,1 & 2,702 & 0,578 & 36,6 & 57,2 \\
\hline
\end{tabular}


Devido ao fato de ser um solo arenoso, o limite de liquidez é baixo, pois possui pequena quantidade de argilominerais pouco ativos. Por isso, quando o solo é saturado, ele perde sua estrutura, podendo se liquefazer e tornar-se instável.

Os resultados dos ensaios de azul de metileno (Tabela 4) foram interpretados com auxílio de ábacos sugeridos por Fabri (1994) e Pejon (1992). Dessa forma, as amostras foram classificadas com relação ao tipo de argilomineral, sua atividade e comportamento laterítico, segundo valores de $\mathrm{Vb}$ e Acb (Tabela 12).

Tabela 12 - Atividade dos argilominerais dos solos estudados e comportamento laterítico segundo classificação de Fabri (1994).

\begin{tabular}{ccccc}
\hline \multirow{2}{*}{ Amostra } & \multirow{2}{*}{ Tipo } & Atividade & \multicolumn{2}{c}{ Comp. Laterítico } \\
\cline { 4 - 5 } & Fabri (1994) & Vb & Acb \\
\hline 1 & Caulinita & Pouco ativa & Laterítico & Laterítico \\
2 & Caulinita & Pouco ativa & Laterítico & Laterítico \\
3 & Caulinita & Pouco ativa & Laterítico & Laterítico \\
\hline
\end{tabular}

As amostras, classificadas como pouco ativas, representam solos bastante evoluídos, de comportamento laterítico, formados por solos enriquecidos através de intemperismo por óxidos de ferro e/ou alumínio de coloração típica vermelho, amarelo, marrom e alaranjado.

Para todas as amostras, observou-se que as curvas resultantes do ensaio ATD (Figura 49 a Figura 51) são características de caulinita com forte reação endotérmica de desidroxilação em torno de $575^{\circ} \mathrm{C}$ e outro pico exotérmico, correspondente à nucleação da mulita, a aproximadamente $950^{\circ} \mathrm{C}$. Entretanto, como as amostras foram secas a temperatura de $50^{\circ} \mathrm{C}$ antes do ensaio, a reação endotérmica em torno de $140^{\circ} \mathrm{C}$ se deve ou à água adsorvida na superfície externa dos argilominerais ou à água entre camadas de argilas 2:1, total ou parcialmente expansivas.

Os argilominerais presentes nos solos foram classificados como caulinita, através de ensaios de adsorção de azul de metileno, e os solos classificados como de comportamento laterítico. A caulinita, de pouca atividade, é resultante da evolução de vários outros argilominerais. 
As curvas características obtidas com a integração de dados do ensaio de funil de placa porosa e de papel filtro são representativas de solos arenosos com baixa capacidade de retenção de água. Observa-se que há uma queda brusca dos valores de umidade correspondentes a um mesmo valor de sucção (desaturação), que está compreendido entre 5 a 10kPa. Verifica-se, através dos índices físicos, que as amostras se encontram no local com baixa porosidade, o que causa um achatamento da curva de retenção, fazendo com que a umidade necessária para saturação do solo seja menor que na condição de alta porosidade (solo fofo).

\section{2 - Erodibilidade}

Analisando as curvas para a Amostra 1 (Figura 56), verificou-se que não há relação entre a inclinação da rampa e a perda de solo para os dois tipos de ação da água (laminar e gota). Para a Amostra 2, constatou-se que a influência da ação da gota depende da inclinação do terreno, ou seja, quanto maior a inclinação, maior é a perda de solo (Figura 57.b). Porém, para o escoamento laminar, essa relação não foi observada, uma vez que as perdas foram praticamente iguais independentemente da inclinação (Figura 57.a).

Foi verificado para a Amostra 3 uma maior perda de solo com o aumento da inclinação nos dois tipos de ensaios (laminar e gota), apesar das curvas para inclinações de rampa maiores $\left(31^{\circ}\right.$ e $\left.50^{\circ}\right)$ apresentarem pequena variação entre si. Para $15^{\circ}$, a gota gera uma perda de solo maior que o escoamento, que nesse solo foi em torno de $50 \%$. Deve-se ressaltar que nos ensaios que procuraram representar a ação da gota, empregou-se uma vazão muito elevada que não representa o histórico de chuvas que ocorre na área.

Os resultados dos ensaios Inderbitzen representados por faixas granulométricas são apresentados nos APÊNDICES A.1 a A.3. Em geral, verifica-se que há uma maior perda de partículas de menor dimensão (retido entre as peneiras $n^{\circ} 50$ e $n^{\circ} 100$ ) com inclinações baixas $\left(15^{\circ}\right)$, ou seja, com o aumento da intensidade da solicitação, maior será a capacidade da água de carrear os grãos de maior dimensão (retidos na peneira $\mathrm{n}^{\circ} 50$ ) em 
detrimento dos grãos retidos entre as peneiras $n^{\circ} 50$ e $n^{\circ} 100.0$ material mais fino (retido entre as peneiras $n^{\circ} 100$ e 200) é totalmente carreado para todas as inclinações e para todas as amostras estudadas.

A interpretação dos resultados dos ensaios Inderbitzen realizados podem não ser o mais apropriado para representar o comportamento do local estudo, pois seria necessário um maior número de ensaios para permitir avaliar a repetibilidade desses resultados, especialmente devido a variabilidade dos materiais que ocorrem na área.

A Figura 74 a Figura 76 mostram os resultados em termos de perda de solo por tensão cisalhante. Com esses gráficos é possível determinar a taxa de erodibilidade (K) e a tensão crítica de cisalhamento $\left(\tau_{\text {Hcrit }}\right)$.

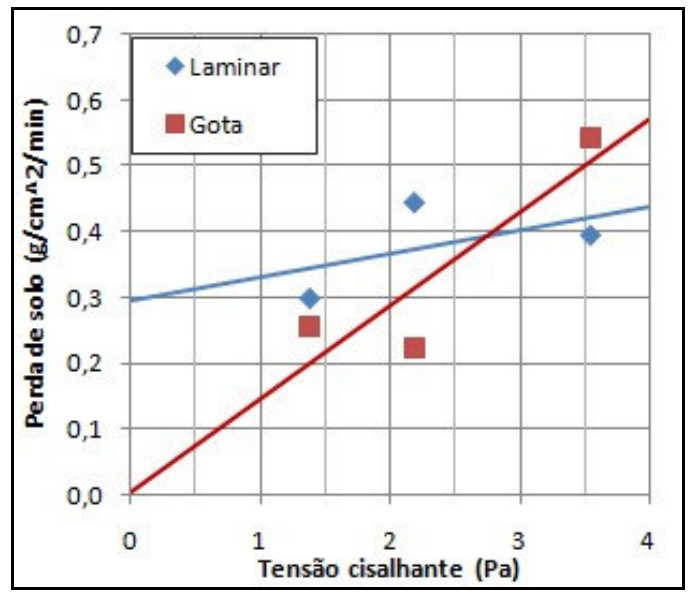

Figura 74. Gráficos para interpretação do ensaio Inderbitzen para a amostra 1

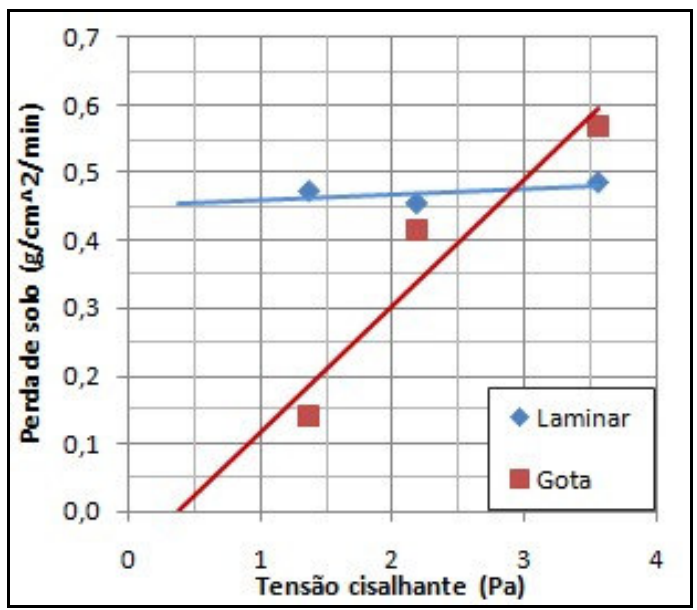

Figura 75. Gráficos para interpretação do ensaio Inderbitzen para a amostra 2 


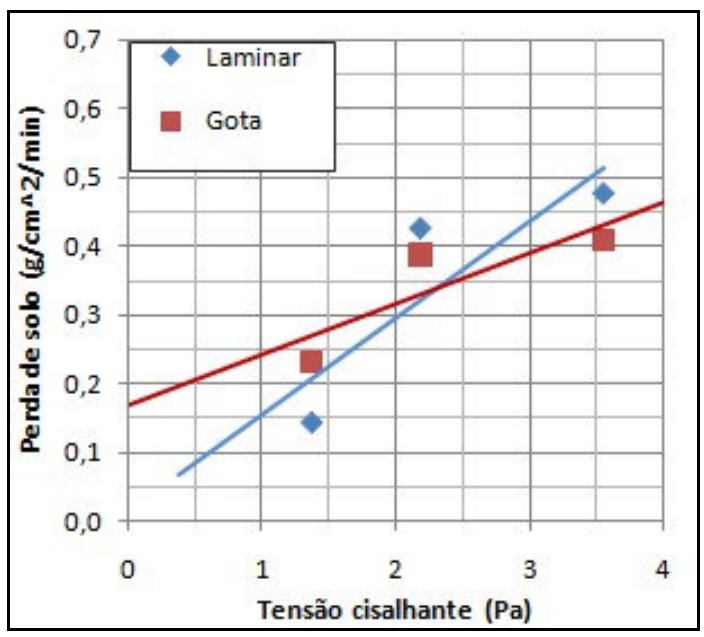

Figura 76. Gráficos para interpretação do ensaio Inderbitzen para a amostra 3

Conforme a classificação de Bastos (1999), todos os resultados obtidos são característicos de materiais de alta a média erodibilidade, pois possuem uma taxa de erodibilidade $(\mathrm{K})$ maior que $0,1 \mathrm{~g} / \mathrm{cm} 2 / \mathrm{min} / \mathrm{Pa}$ ou no intervalo entre $\mathrm{O}$ valor anterior $\mathrm{e}$ 0,001 $\mathrm{g} / \mathrm{cm} 2 / \mathrm{min} / \mathrm{Pa}$, como pode ser observado na Tabela 13, para as três inclinações de rampa empregadas. Entretanto, observou-se valores distintos entre a erodibilidade medida nos ensaios de escoamento laminar e ação de gota. Nos ensaios realizados as tensões cisalhantes críticas $\left(\tau_{\text {crit }}\right)$ foram negativas, pois a perda de solo é muito alta para tensões cisalhantes baixas. Isso causa o achatamento da reta, o que faz com que o coeficiente angular (K) seja pequeno.

Tabela 13 - Parâmetros resultantes do ensaio Inderbitzen para as três amostras estudadas

\begin{tabular}{ccc}
\hline \multirow{2}{*}{ Amostra } & Laminar & Gota \\
\cline { 2 - 3 } & $\begin{array}{c}\mathrm{K} \\
\left(\mathrm{g} / \mathrm{cm}^{2} / \mathrm{min} / \mathrm{Pa}\right)\end{array}$ & $\begin{array}{c}\mathrm{K} \\
\left(\mathrm{g} / \mathrm{cm}^{2} / \mathrm{min} / \mathrm{Pa}\right)\end{array}$ \\
\hline 1 & 0,036 & 0,141 \\
2 & 0,008 & 0,187 \\
3 & 0,140 & 0,042 \\
\hline
\end{tabular}

Em suma, o ensaio Inderbitzen permitiu avaliar a influência da inclinação do terreno na perda de solo por escoamento laminar ou pelo impacto da gota. Os resultados dos ensaios representados nas curvas de perda de solo acumulada versus tempo para as três amostras não seguiram um único padrão. Logo, as amostras analisadas, mesmo coletadas 
num mesmo local erodido, não mostraram uma tendência, tanto com o aumento da inclinação, quanto com a troca do escoamento laminar pela ação da gota.

Outros ensaios de erodibilidade utilizados foram o de absorção de água e o de perda por imersão (MCT), cuja síntese dos resultados está apresentada na Figura 77. As linhas representam os limites propostos por Nogami \& Villibor (1979) e por Pejon (1992) para diferenciar no gráfico as regiões de alta e baixa erodibilidade.

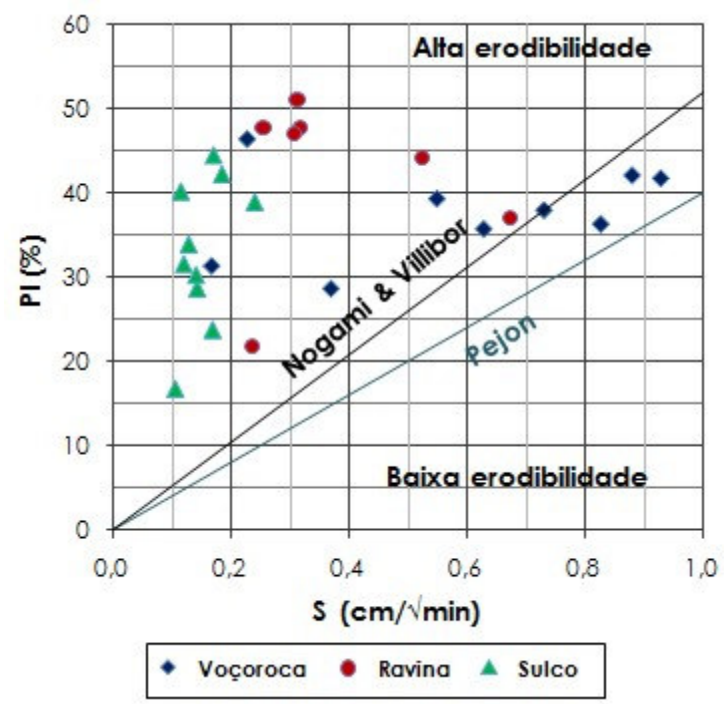

Figura 77. Ábaco com resultados dos ensaios de absorção de água para avaliação da erodibilidade das amostras estudadas

Nogami \& Villibor (1979) estudaram vários solos do estado de São Paulo e verificaram que o limite definido por eles classificava corretamente mais de $90 \%$ das amostras de erosão em taludes de corte. Enquanto Pejon (1972), que estudou solos da região de Piracicaba especificamente, explica que seu limite obteve cerca de $80 \%$ de bons resultados. Verifica-se que, na maioria dos ensaios, o limite proposto por Nogami \& Villibor (1979) classifica as amostras como erodíveis. Entretanto, é o limite proposto por Pejon (1992) que engloba todos os resultados obtidos, sendo assim mais indicado para classificar os solos do local estudado. Também se observa que as amostras apresentam resultados bem variáveis alternando de erodíveis a altamente erodíveis. 
O terceiro tipo de ensaio utilizado para avaliar a erodibilidade dos solos foi o de penetração de cone. Constatou-se que alguns resultados não foram representativos do comportamento de campo, pois classificaram o solo como de baixa erodibilidade, como mostrado na Figura 78. Observando também que a variação de $\pm 5 \%$ da leitura média, proposta por Alcântara \& Vilar (1998), nos solos heterogêneos estudados diminuem consideravelmente o número de dados do ensaio que podem ser utilizados.

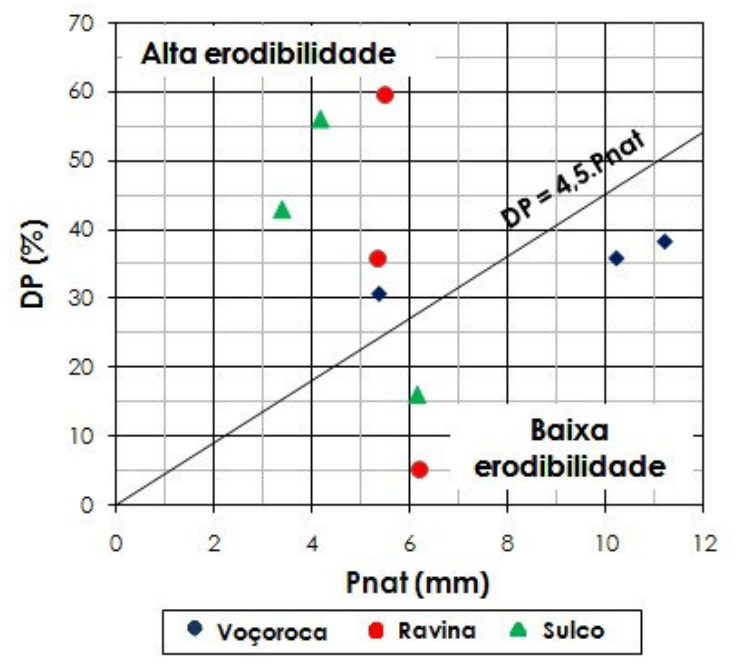

Figura 78. Ábaco com resultados dos ensaios de penetração de cone para avaliação do grau de erodibilidade do solo

Por essas razões foram realizados ensaios de penetração de cone com períodos de saturação de 2, 4 e 8 horas para avaliar qual representaria melhor o limite de DP sugerido por Alcântara \& Vilar (1998). Constatou-se que o aumento do período de saturação da amostra não elevou o teor de umidade do corpo-de-prova, que já se encontrava praticamente saturado após uma hora em contato com a água. Assim, não foi possível observar alteração significativa nos resultados em relação ao procedimento convencional. Na umidade natural, os resultados dos ensaios não variaram significativamente, pode-se afirmar que a variação de $P_{n a t}$ (média das leituras de penetração na condição de campo) se deve à heterogeneidade do solo e não à ação da sucção do solo.

Dessa forma, as amostras estudadas possuem alta erodibilidade, ou seja, suas partículas são facilmente destacadas e transportadas pela ação da água. Tal ação foi 
avaliada através do ensaio de absorção de água, da resistência à penetração de um cone em corpos-de-prova na condição natural e saturada, da ação da gota destacando as partículas e do carreamento de tais partículas de solo através de fluxo superficial do tipo laminar (ensaio Inderbitzen).

\section{3 - Resistência e comportamento de solo não-saturado}

O ensaio de cisalhamento direto apresentou resultados característicos de um solo arenoso. Os valores de ângulo de atrito foram, tanto para a condição natural, como para a condição inundada, variáveis entre $30^{\circ}$ e $40^{\circ}$. Outra característica observada é o paralelismo das envoltórias de resistência, ou seja, o efeito da inundação no solo resultou principalmente na diminuição da coesão, não afetando significativamente o ângulo de atrito (Figura 63 a Figura 65, respectivamente para as amostras 1 a 3).

A curva característica dos solos estudados também é típica de um solo arenoso apresentando comportamento bimodal. Tal comportamento é representado por duas pressões de entrada de ar, uma correspondente ao efeito de sucção nos macroporos e outra ao efeito dos microporos (Figura 53 a Figura 55, respectivamente para as amostras 1 a 3).

As envoltórias de resistência determinadas foram analisadas considerando os teores de umidade para as três amostras, no estado natural e inundado, no intuito de avaliar a influência da sucção a partir das curvas características nas propriedades mecânicas do solo estudado. Esta representação encontra-se na Figura 79 a Figura 81, respectivamente para as amostras 1 a 3, nas quais tem-se as envoltórias de resistência (letra "a") e as curvas características (letra "b"). 

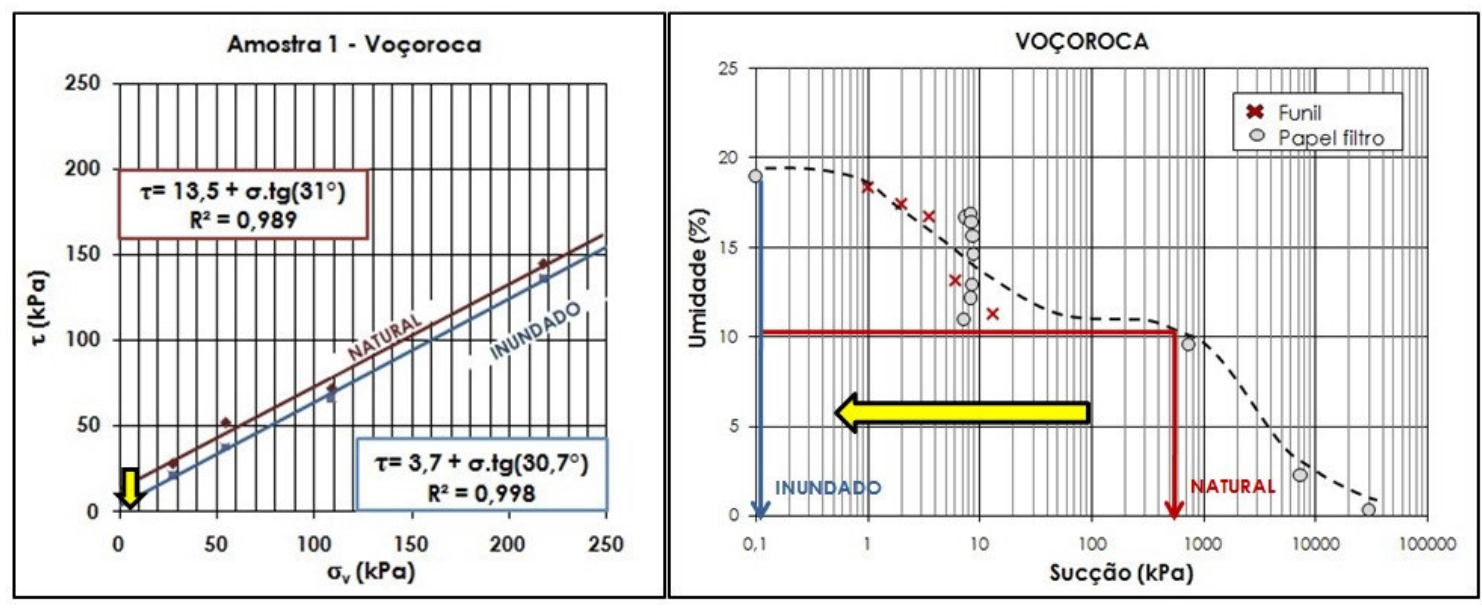

a) envoltória de resistência

b) curva característica

Figura 79. Influência da sucção na resistência para a amostra 1

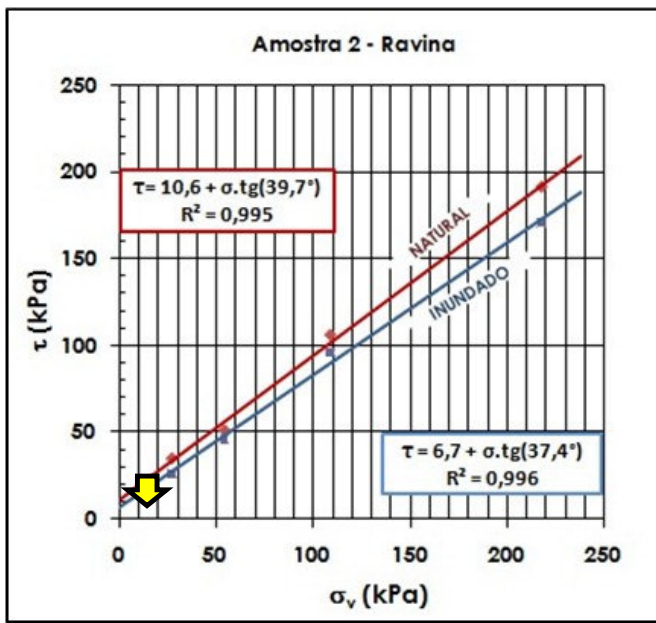

a) envoltória de resistência

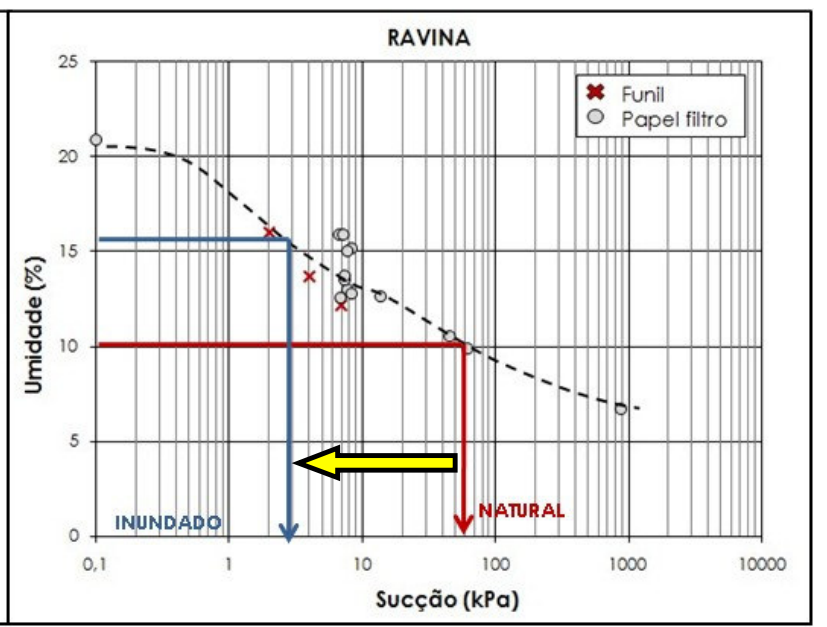

b) curva característica

Figura 80. Influência da sucção na resistência para a amostra 2

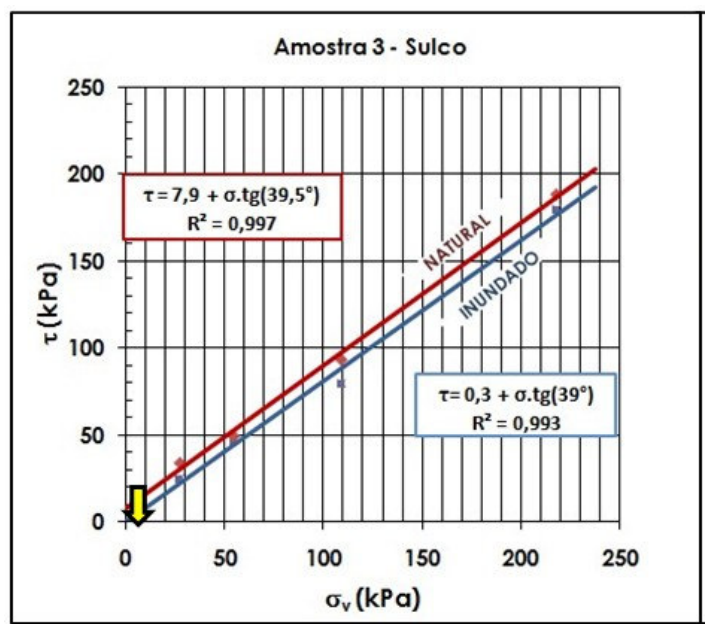

a) envoltória de resistência

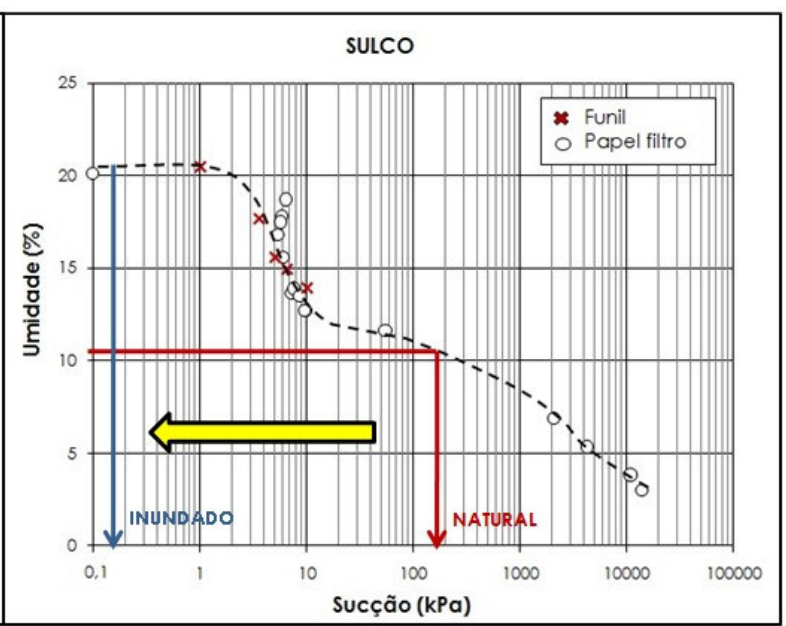

b) curva característica

Figura 81. Influência da sucção na resistência para a amostra 3 
Os valores de umidade dos ensaios realizados na condição natural e inundada foram lançados na curva característica de cada amostra para que fosse possível identificar a variação de sucção correspondente às umidades citadas. Obtiveram-se assim, para as três amostras, variações da umidade natural de $10 \%$ a $11 \%$ e, da umidade inundada, de $17 \%$ a 20\%. Tais valores representam variações na sucção matricial de praticamente zero para valores próximos a $800 \mathrm{kPa}$ para a amostra 1, $80 \mathrm{kPa}$ para a amostra 2 e $90 \mathrm{kPa}$ para a amostra 3. Logo, a inundação do corpo-de-prova, causou uma diminuição do efeito da sucção a valores próximos a zero.

Constatou-se para todas as amostras estudadas que a variação do ângulo de atrito em função da diminuição da sucção matricial não foi significativa. Ao contrário, verificou-se que a coesão do solo diminuiu com a inundação do corpo-de-prova, confirmando a influência da sucção matricial em favor da resistência do solo não-saturado. Dessa forma, os resultados corroboram os de Teixeira (1996), que também estudou a resistência de um solo arenoso laterítico não-saturado.

Analisando os resultados do ensaio de compressão edométrica na condição natural e inundada, pode-se novamente ressaltar o efeito da ação da sucção matricial em favor da rigidez do solo. Na umidade natural, o solo apresentou uma tensão de pré-adensamento maior que a tensão obtida na condição inundada (Tabela 8).

Os resultados de ensaios de cisalhamento direto na condição natural e inundada destacam que a inundação do solo causa uma redução significativa da sucção matricial e, conseqüentemente, no valor do intercepto de coesão, fato importante que deve ser considerado quando se estuda o processo de evolução das erosões na área.

\section{4 - Ensaios de campo}

\subsection{1 - Alterações nos solos provocados pelo fluxo d'água}

Sondagens de simples reconhecimento foram realizadas transversalmente ao processo erosivo visando estudar as mudanças nas características texturais e mineralógicas 
do solo provocadas pelo fluxo d'água no interior do talude. A Figura 82 mostra o perfil transversal resultante fornecido por empresa contratada. É possível constatar novamente que as diferentes camadas de solo, apesar da variabilidade, tem continuidade e há somente uma variação de sua espessura.

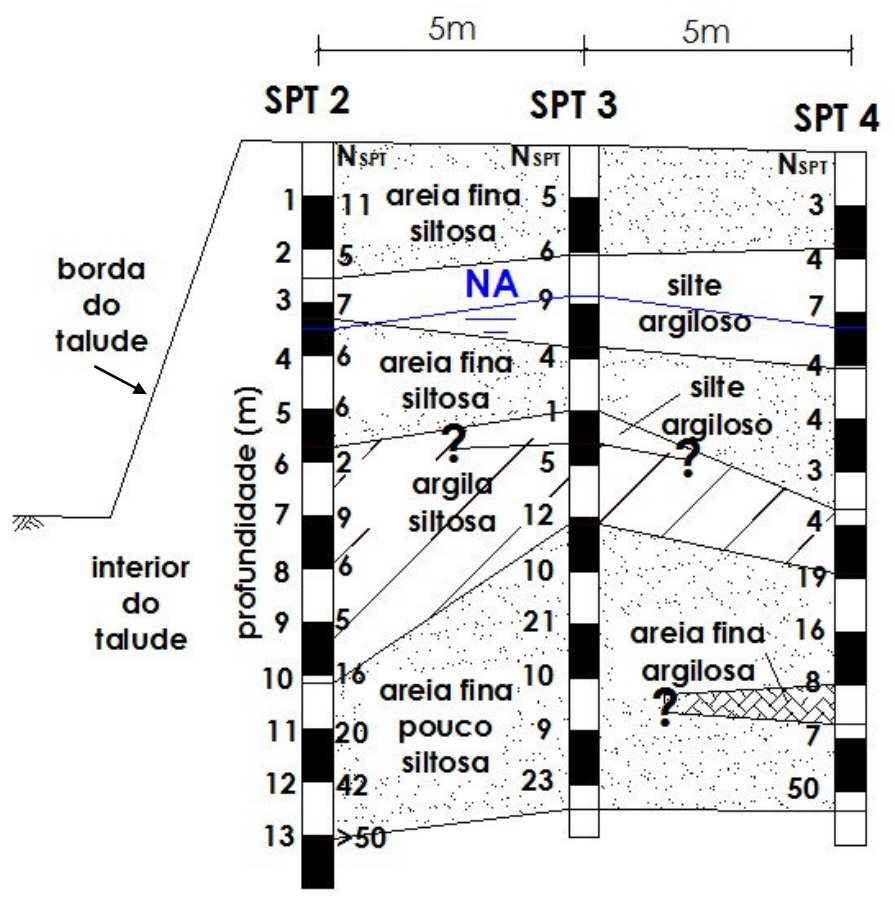

Figura 82. Perfil transversal interpretado a partir do resultado das sondagens

As amostras deformadas coletadas durante as sondagens de simples reconhecimento possibilitaram a realização de ensaios de granulometria conjunta e avaliar a variação da composição granulométrica ao longo da profundidade próxima à borda do talude da erosão (SPT 2), distante 5m (SPT 3) e 10m (SPT 4) é apresentada na Figura 83. 


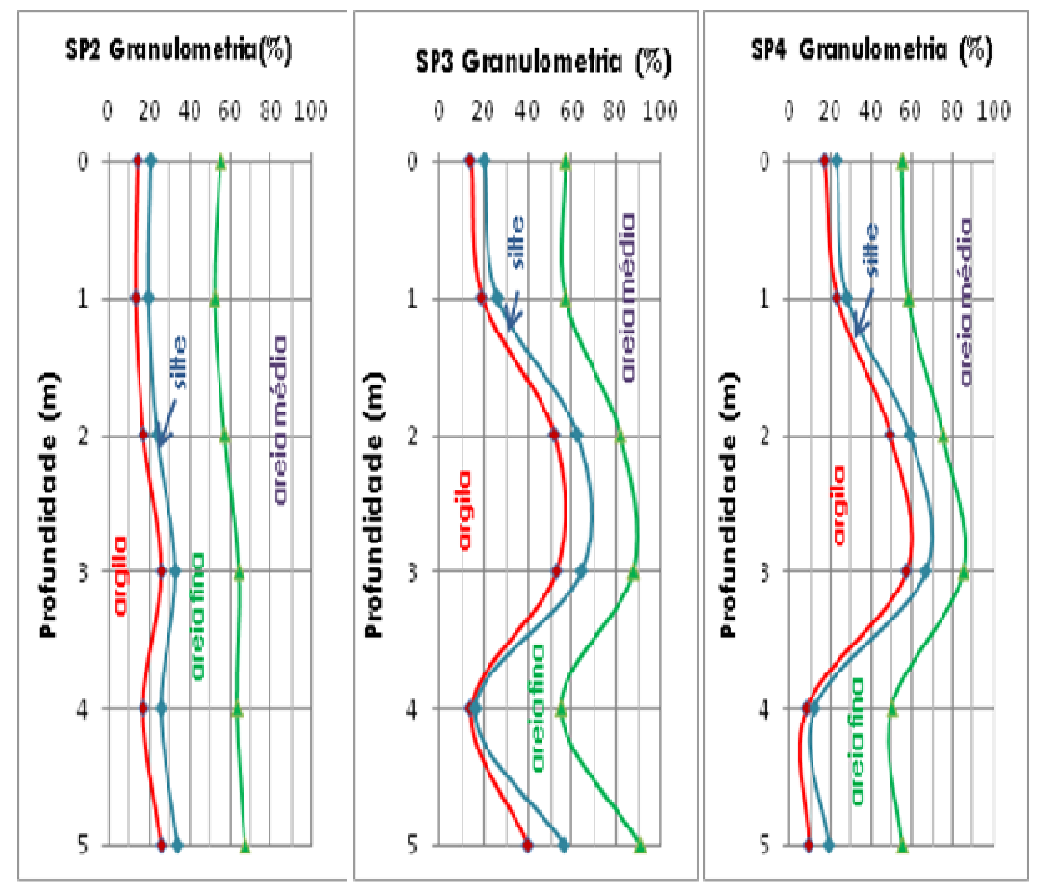

Figura 83. Variação da granulometria ao longo do perfil transversal

A Figura 83 possibilitou constatar o efeito do fluxo de água no interior do talude no sentido transversal à erosão, pois a variação da porcentagem de argila é claramente notada à medida que se afasta da borda do talude. É possível analisar que, na borda do talude (SPT 2), a quantidade de argila é muito menor que a 5m (SPT 3) e 10m (SPT 4) de distância da borda do talude, mostrando a influência do fluxo de água em direção à sua face. Quanto mais distante do talude, maior é a porcentagem de argila, pois o fluxo de água tende primeiramente a carrear os finos mais próximos à sua borda. O inverso ocorre com a porcentagem de areia, que é maior nas bordas do talude e diminui quanto mais se distancia da borda.

Em todas as amostras coletadas das sondagens foi observado que os valores de $\Delta \mathrm{pH}$ são negativos (Figura 84), o que indica que o solo não apresenta um estágio avançado de evolução, sendo o teor de oxi-hidróxidos de ferro e alumínio menor que a presença de argilominerais. Em geral, a diferença entre eles diminui mais próximo à superfície, o que confirma que o solo se encontra mais intemperizado e evolvído nos horizontes mais superficiais. Logo, os resultados desse ensaio estão de acordo com dos ensaios de adsorção 
de azul de metileno, que indicaram presença de caulinita e solo de comportamento laterítico, já que as mesmas foram coletadas mais próximas a superfície do terreno.

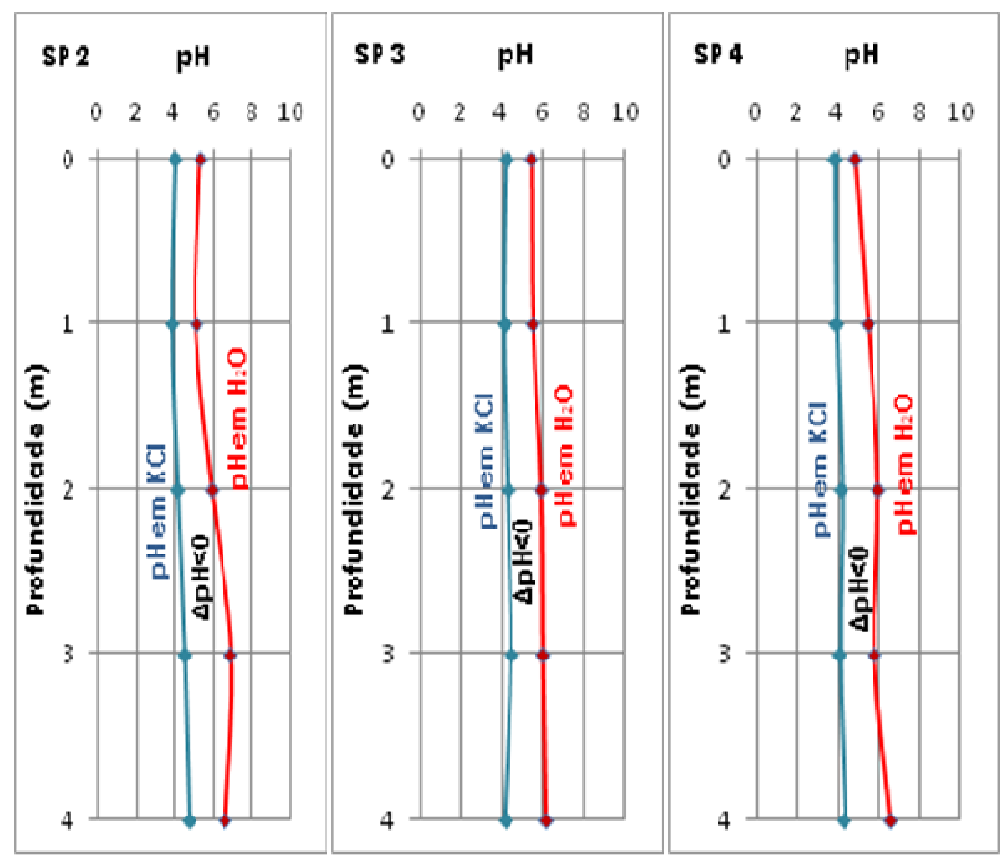

Figura 84. Variação do pH ao longo do perfil transversal à erosão

A variação do pH possibilitaria uma análise da influência do fluxo de água no talude através do grau de intemperismo do solo. Nessa análise, verificou-se que o fluxo no interior do maciço reduz a quantidade de argilominerais, pois os carreia para fora. Através da análise de $\Delta \mathrm{pH}$, pode-se assumir que o solo não apresenta o teor de oxi-hidróxidos de ferro e alumínio maior que a quantidade de argila, fato justificado pela nível d'água raso e fluxo de água superficial. Entretanto, verificou-se que quanto mais próximo a superfície, menor é o $\Delta \mathrm{pH}$, ou seja, maior é o teor de oxi-hidróxidos de ferro e alumínio e, conseqüentemente, mais intemperizado é solo. 


\subsection{2 - Ensaios de campo}

Na Figura 85 está representado o perfil interpretado para a sondagem de simples reconhecimento número 2, que pode ser considerado típico do local estudado. Nela consta o perfil interpretado pela empresa contratada (Figura 85.a) com base na identificação tátil e visual do mestre sondador e a segunda representação (Figura 85.b) correspondente aos resultados dos ensaios de granulometria conjunta realizados de metro a metro com as amostras coletadas durante o ensaio.

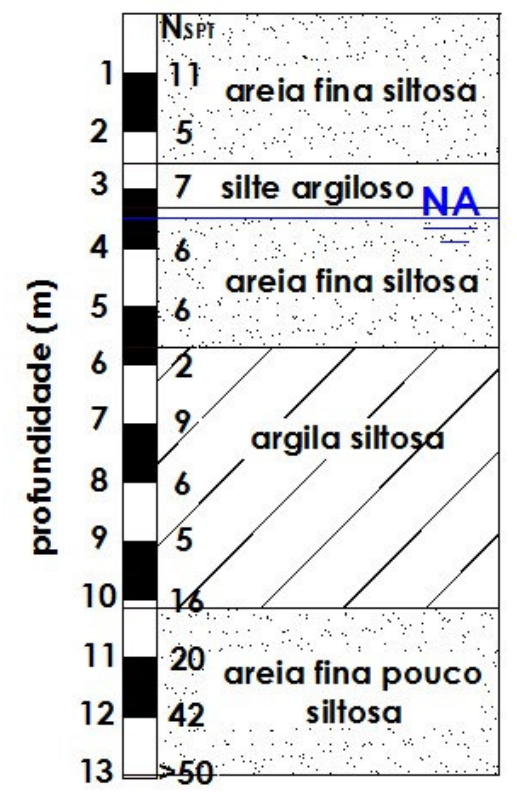

a)identificação tátil visual

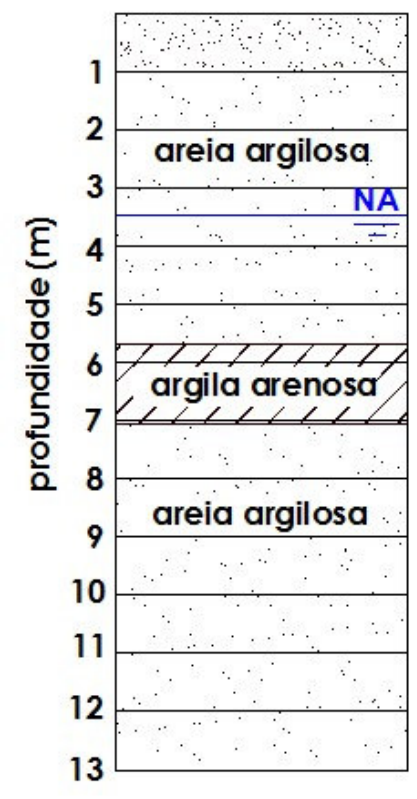

b) ensaios de granulometria conjunta

Figura 85. Perfis de sondagem obtido a partir da sondagem 2

Os ensaios de granulometria conjunta realizados nas amostras coletadas a cada metro das sondagens mostraram que o perfil de solo fornecido pela empresa contratada não corresponde ao obtido nos ensaios de laboratório. Esse fato pode estar associado ao efeito da agregação dos finos ou com outros grãos de solo, como verificado nos resultados do ensaio de granulometria conjunta com e sem defloculante, bem como pela falta de experiência do mestre sondador. 


\section{5 - Observações de campo}

Em geral, o processo de evolução da erosão observado em campo se dá pela concentração de água em certos pontos do terreno que carreiam o solo, gerando um alívio de tensão no terreno. Esse fato, associado à formação de trincas de retração e ao fluxo à jusante, resulta em tombamentos, quedas ou escorregamentos em fatia do material instável (Figura 86). Esses movimentos de massa ocorrem porque há o solapamento da base devido aos seguintes fatores: fluxo de água, liquefação do solo e alívio de pressões, que contribuem com a evolução do processo erosivo.

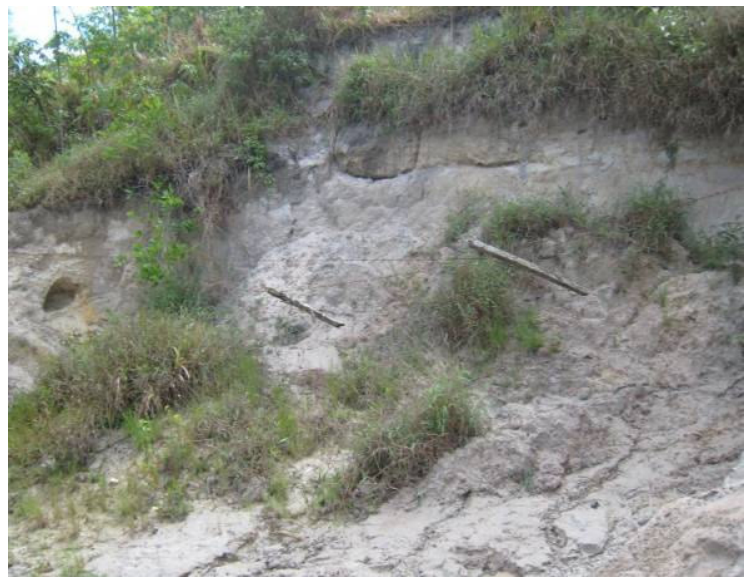

Figura 86. Escorregamento em fatias devido ao fluxo de água na base do talude no local de coleta da amostra 1

Na área estudada, observou-se que a distância das trincas de retração da borda do talude é maior em pontos nos quais a erosão encontra-se evoluída, ou seja, as fatias de escorregamento são maiores e mais espessas. Além disso, notou-se que novos ramos estão se formando a partir de escorregamentos nas bordas dos taludes, nas regiões onde há maior concentração de água de chuva.

Também pôde ser observada a cimentação superficial do solo em todos os locais de coleta de amostras. As espessuras variam de milímetros, encontradas na ravina, a centímetros, verificadas nas voçorocas. Algumas vezes, devido à cimentação superficial e 
ao ressecamento do solo, uma camada fina superficial se mantém estável, mas, à medida que o material da base é retirado, ela se desprende como o resto do material.

A evolução do processo, constatada a partir de levantamentos topográficos da borda do talude (Local 1), com o tempo pode ser avaliado no gráfico que representa o avanço do processo erosivo no tempo, conforme ilustrado na Figura 87. O início dos registros corresponde ao mês de junho de 2008, logo o décimo e último mês de análise corresponde ao mês de abril de 2009. A Figura 87 representa o avanço do fenômeno no ponto mais crítico do Local 1, identificado na Figura 69.

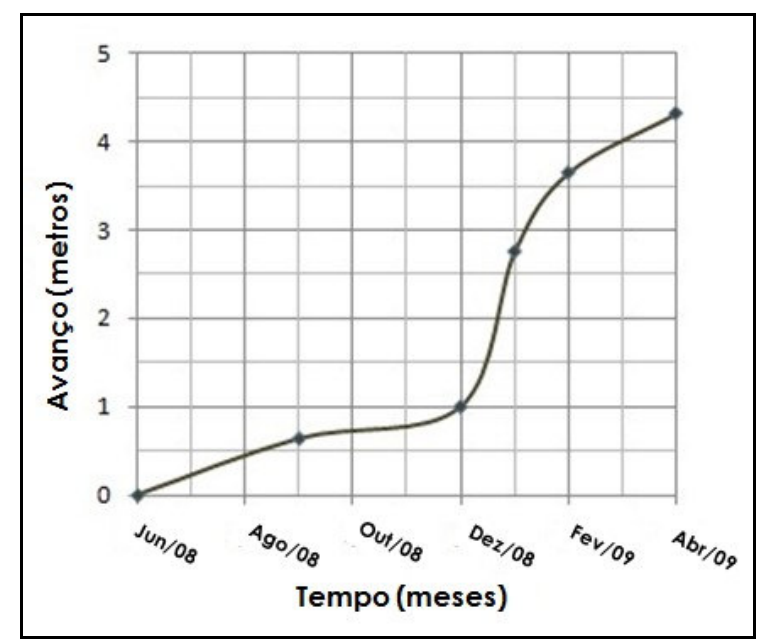

Figura 87. Representação do avanço do processo erosivo por mês observado com levantamentos topográficos em ponto mais crítico do Local 1

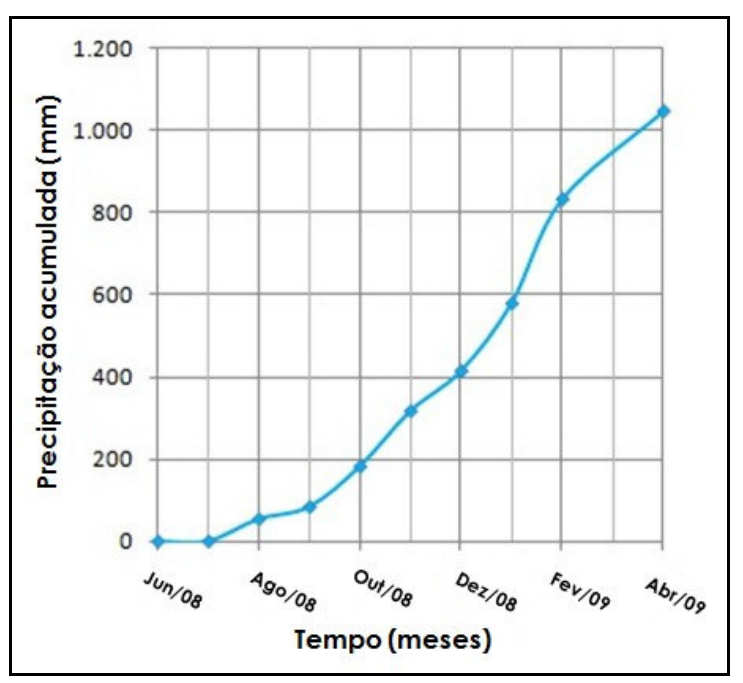

Figura 88. Representação da precipitação acumulada por mês no local estudado 
Através dos dados de precipitação fornecidos pelo Instituto de Pesquisas Meteorológicas da UNESP de Bauru (IPMET), observa-se que a quantidade de chuva, representada na Figura 88 pela precipitação acumulada, é determinante para o avanço da erosão. Entretanto, essa relação não é direta, como se pode analisar os meses de janeiro/09 e fevereiro/09. No mês de janeiro, observou-se um avanço de aproximadamente $2 m$, enquanto no de fevereiro foi de $1 \mathrm{~m}$, mesmo com uma maior quantidade de chuva.

Como observado através dos índices físicos das amostras ensaiadas, a umidade de saturação do solo é maior que o limite de liquidez. Para o solo estudado, o efeito da sucção foi verificado com a inundação do corpo-de-prova no ensaio de cisalhamento direto, que causou a diminuição da sua resistência, com a redução da coesão aparente, conforme demonstrado na Figura 79 a Figura 81. Logo, quando há chuvas, a ruptura da estrutura do solo pode ocorrer por excesso de umidade, ou seja, o solo pode se liquefazer e ser carreado, levando a novas instabilizações, fato que foi observado no campo e ilustrado na Figura 72. Nos locais nos quais o lençol freático foi atingido pelo processo erosivo, a região próxima à base do talude se liquefaz, fato verificado através do fenômeno de areia movediça quando se solicita o terreno com alguma carga.

O avanço do processo erosivo é observado em todos os locais de retirada das amostras estudadas, que variam desde um solo residual jovem com características da rocha mãe a um sedimentar. A principal forma de avanço são os escorregamentos em fatias devido à remoção de material confinante, o que causa alívios de pressão no terreno, e ao fluxo de água à jusante, que solapa a base do talude (Figura 89). Tais escorregamentos de superfície de ruptura circular geram uma estabilidade temporária, pois o solo escorregado (Figura 72) é logo removido pelo fluxo de água na base do talude, semelhante ao observado por Futai et al. (2005). 


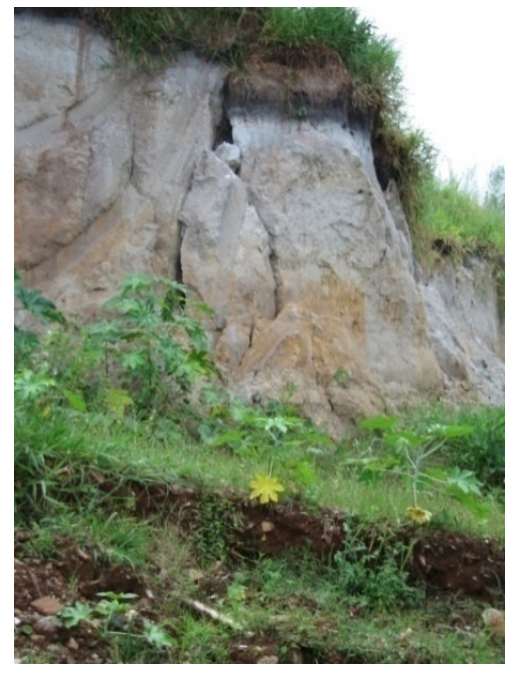

Figura 89. Escorregamento por alívio de pressão e solapamento da base

Como as cabeceiras do processo foram controladas com obras de contenção, a evolução só foi avaliada nas paredes das voçorocas. Nelas, normalmente, é possível verificar o fenômeno de erosão interna retrogressiva, que carreia partículas de solo e facilita a ocorrência de novos escorregamentos. O fluxo de água do interior do talude para sua face faz com que o solo seja carreado, formando assim vazios em forma de canais, característicos do fenômeno. Na área em estudo, é possível verificar a formação dos canais mesmo em um local no qual ocorre erosão em forma de sulcos e ravinas (Figura 73). O fato ocorre porque o nível d'água é raso e o córrego encontra-se assoreado devido à erosão, fazendo com que a água surja na superfície do terreno.

Uma simulação do comportamento em campo no local de coleta da amostra 1 foi feita empregando-se o Geoslope, ferramenta do programa GeoStudio para simular escorregamentos. Esse local foi escolhido porque é onde o processo erosivo está em estágio avançado (voçoroca). Dessa forma, a Figura 90 representa o avanço do processo erosivo, que ocorre por escorregamentos sucessivos em fatias.

Admitiu-se o solo na condição natural (Figura 90 - NATURAL) para que fosse possível avaliar somente a influência da remoção e da deposição de solo na base do talude. O nível d'água foi simulado com profundidade de aproximadamente $3 \mathrm{~m}$, conforme resultado das sondagens de simples reconhecimentos (com medida SPT) realizadas. É importante ressaltar 
que muitos fatores podem influenciar o processo, e assim diminuir o coeficiente de segurança e não foram considerados, por isso os valores apresentados são todos maiores que um para a condição natural do solo. Dentre esses fatores, podem ser citados: a saturação do solo e a subida no nível d'água com a chuva, o fenômeno de erosão interna retrogressiva e a sobrecarga causada pela vegetação à montante do talude. Além disso, as mesmas condições foram simuladas para um solo quase saturado. Os parâmetros de resistência e índices físicos utilizados são aqueles determinados a partir dos ensaios de cisalhamento direto na condição natural e inundada, na qual foi verificada uma diminuição do efeito da coesão em relação ao ensaio natural.

Quando o solo está em sua condição natural, seu fator de segurança para um talude com inclinação de $65^{\circ}$ é de 1,471 (Figura 90.a.1). Com o aumento do teor de umidade, essa condição de estabilidade é perdida, fato representado pela diminuição do fator de segurança para 0,850 (Figura 90.a.2). Assim, com a liquefação do material da base do talude e sua posterior remoção, ocorrem escorregamentos em fatias com deposição do solo escorregado.

O material depositado deixa o restante do talude estável, fato que corresponde ao aumento do coeficiente de segurança, tanto para o solo na condição natural (Figura 90. b.1), como na inundada (Figura 90.b.2). O fluxo de água superficial carreia aos poucos o solo depositado, diminuindo o fator de segurança de 1,739 para 1,569 (Figura 90.c.1) quando em condição natural.

O aumento do peso próprio do maciço, devido ao aumento do teor de umidade, em conjunto com a redução de resistência do solo causada pela água causam instabilizações sucessivas do talude, agravadas por fenômenos de erosão interna retrogressiva, que ocorrem na base do talude devido ao fluxo d'água. Dessa forma, os valores do fator de segurança se tornam menores que 1 (Figura 90.c.2). Essa remoção é progressiva até que ocorram novos escorregamentos, que dão continuidade ao processo erosivo. 
a.1) NATURAL

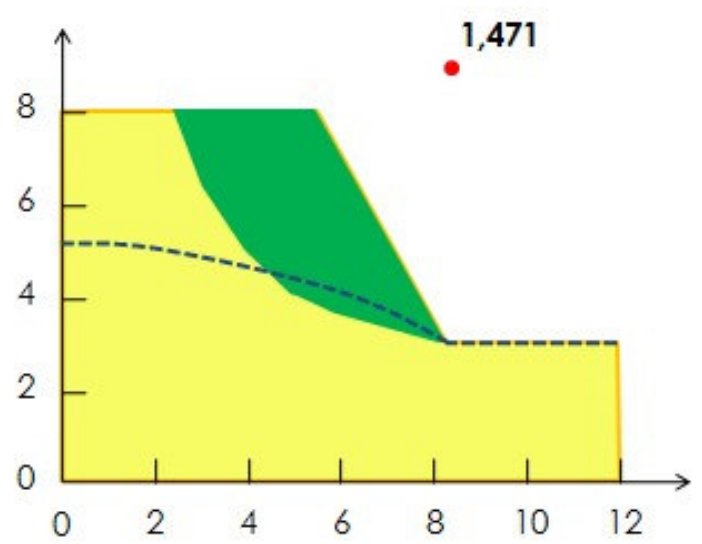

a.2) INUNDADA

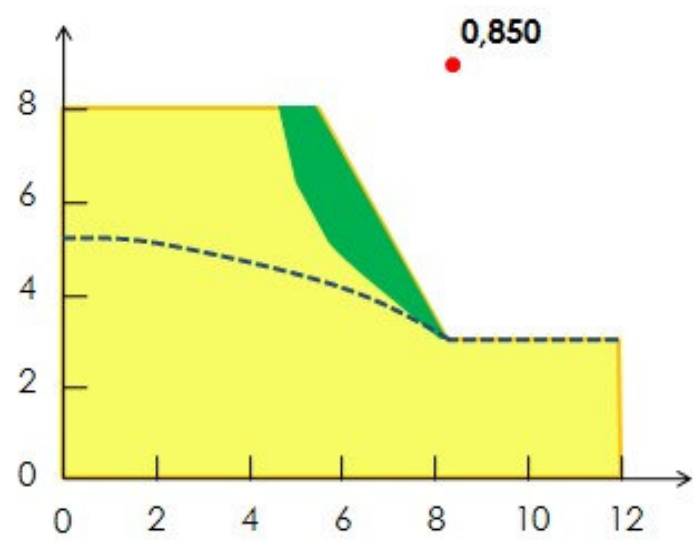

a) Situação inicial do talude no campo

b.1) NATURAL

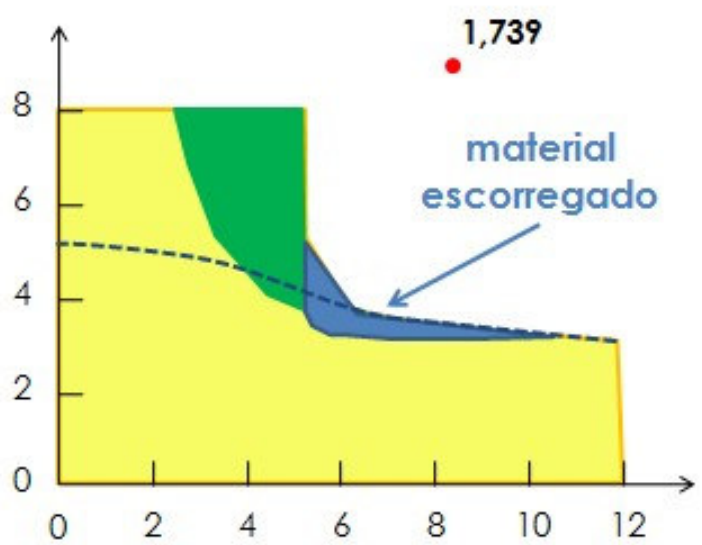

b) Material escorregado e depositado no pé do talude b.2) INUNDADA

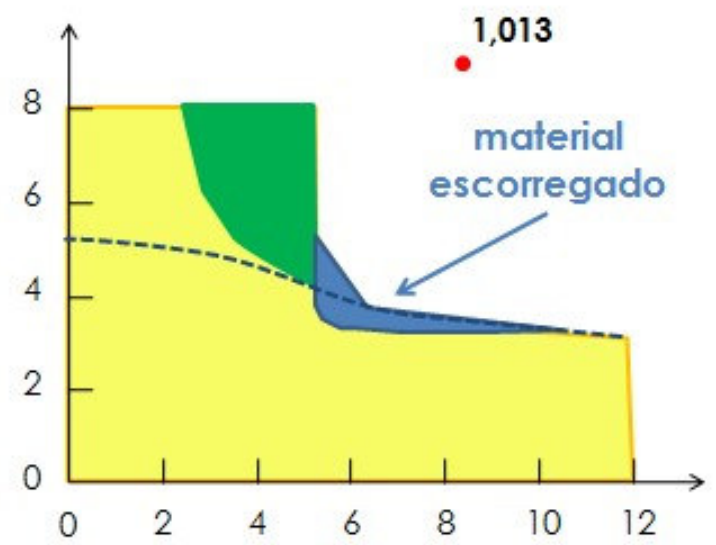

c.2) INUNDADA
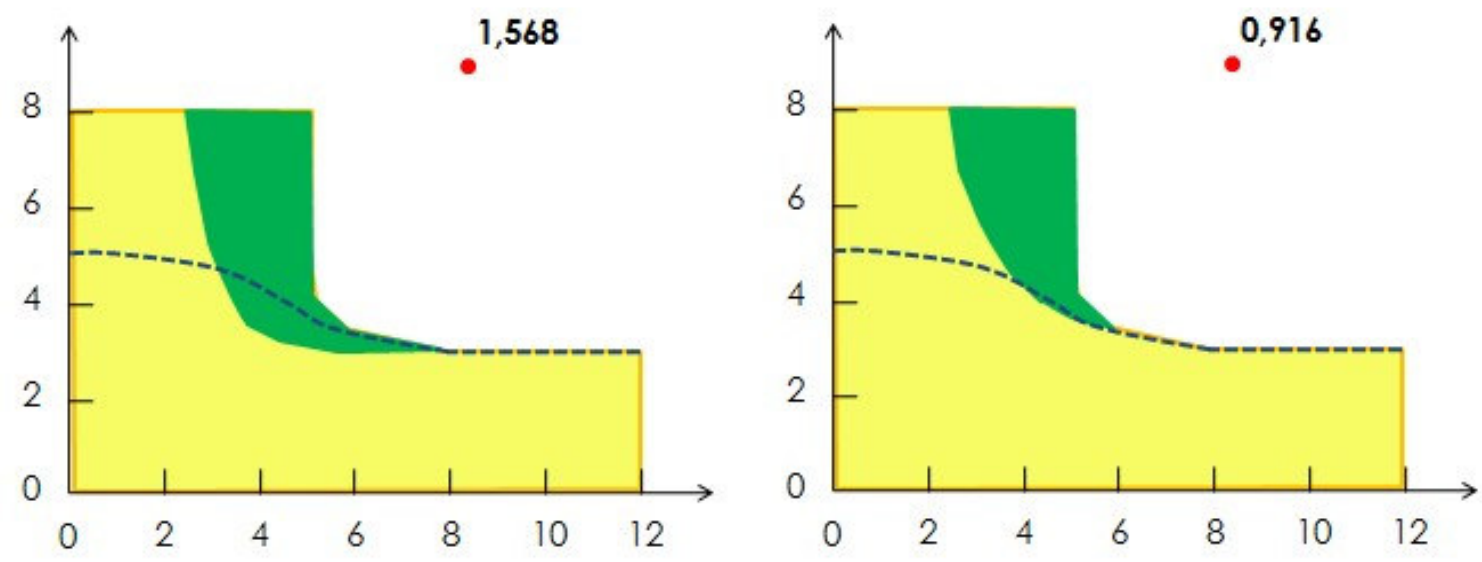

c) Remoção do material escorregado

Figura 90. Representação do mecanismo de instabilização 


\section{7 - CONCLUSÕES E SUGESTÕES PARA CONTINUIDADE}

A ocupação urbana, através da implantação de loteamentos, foi o fator agravante para a evolução dos processos erosivos na área estudada, que é classificada como de alta erodibilidade, segundo IPT (1994). A ramificação do processo erosivo que foi preenchida com entulho já sofreu erosão laminar, que removeu a camada de solo compactado superficial. O avanço do processo nesse local foi reduzido pela vegetação que cresceu, apesar das condições adversas. O chorume exudado e o lixo orgânico depositado no bolsão, que deveria ser somente de entulho, auxiliam a contaminação do solo em conjunto com o esgoto ainda despejado no local. Tal contaminação pode ser verificada a partir dos resultados do ensaio ATG, que apresentou curvas distintas das esperadas, pois os contaminantes afetaram esses resultados.

Os solos estudados são arenosos e apresentam pequena quantidade de argila e ela se agrega a outras partículas, dando a impressão de existência de grãos de maior dimensão, como comprovado nos ensaios de granulometria conjunta. Ou seja, em campo, não é possível identificar os argilominerais, pois essas agregações se comportam como siltes e areias. Além disso, a caulinita, tipo de argilomineral identificado nos ensaios de adsorção de azul de metileno e ATD, é um argilomineral evoluído e pouco ativo e não influencia a evolução desse processo através de fenômenos expansivos, por exemplo.

Alguns resultados de ensaios de laboratório indicam processo pedogenético avançado (solo laterítico), como os de adsorção de azul de metileno. Entretanto, outros não indicaram esse processo, como o ensaio de $\Delta \mathrm{pH}$. Constata-se no local que o solo é muito intemperizado e que realmente sofreu processo avançado de pedogênese, como sugere o ensaio de adsorção azul de metileno. $O$ ensaio de $\Delta \mathrm{pH}$ apresenta um resultado diferente talvez porque as amostras foram retiradas da superfície de taludes do processo erosivo, o que contribui para o carreamento de materiais devido à influência do fluxo de água no talude. Dessa forma, há a possibilidade dos oxi-hidróxidos de ferro e alumínio terem sido carreados com o fluxo de água no interior do talude da erosão. 
Outro fato que confirma a existência de solos lateríticos é a cimentação superficial existente em toda a área em estudo, apesar da resistência do solo ser baixa até aproximadamente $12 \mathrm{~m}$ de profundidade. Esses fatores foram identificados através de sondagens de simples reconhecimento com medida de SPT.

A distribuição granulométrica do solo é modificada pelo fluxo de água transversal ao processo erosivo no interior do talude, pois ele carreia os argilominerais do solo para o exterior do maciço de solo. As análises granulométricas das amostras obtidas em sondagens de simples reconhecimento ao longo da profundidade permitiram chegar a essa conclusão. É o fluxo de água transversal ao processo erosivo que faz com que o solo da base do talude se liquefaça e seja facilmente carreado, além de desencadear a erosão interna retrogressiva. O solo do local de estudo se liquefaz facilmente porque a umidade de saturação é maior que o seu limite de liquidez. Os argilominerais do solo são as primeiras partículas carreadas, devido à sua facilidade de destacamento e carreamento, conforme verificado no ensaio Inderbitzen.

Os ensaios para determinação de índices físicos levam à conclusão de que o solo não se encontra saturado. A saturação desse solo provoca uma redução nos valores do coeficiente de segurança, pois há uma diminuição da resistência. Tal diminuição se deve a praticamente anulação do efeito da sucção, que leva uma redução significativa da coesão, enquanto o ângulo de atrito quase não varia. A associação dos ensaios de cisalhamento direto e de determinação da curva característica do solo foi importante para compreender esse fenômeno. Em campo, a redução da resistência pode ser observada pelos escorregamentos sucessivos que ocorrem, principalmente na época das chuvas.

A alta erodibilidade do solo, obtida em geral em todas as metodologias empregadas, é representativa do comportamento observado em campo. Os resultados dos ensaios Inderbitzen (1961) são preliminares e não devem ser generalizados, pois é necessário realizar um maior número de ensaios devido à heterogeneidade das amostras. Entretanto, já foi possível constatar que nos 10 primeiros minutos de ensaio ocorreram as maiores perdas de solo e, após esse período, elas praticamente se estabilizam. O ensaio de penetração de 
cone apresentou tanto resultados coerentes como inconsistentes com o que se observa em campo. Acredita-se que isso ocorreu devido à heterogeneidade das amostras, que apresentaram resultados muito variáveis entre si. Para a área estudada, o ensaio que apresentou os melhores resultados foi o desenvolvido por Nogami \& Villibor (1979), apesar de ele ter sido desenvolvido para avaliar a erodibilidade de taludes rodoviários.

Através de levantamentos topográficos, se pode associar a ocorrência de eventos pluviosos aos escorregamentos, que caracterizam o principal meio de evolução do processo erosivo no local estudado. Porém, a relação entre quantidade de chuva e avanço da erosão não é linear, por exemplo, no mês de janeiro observou-se o maior avanço apesar de uma precipitação menor que em fevereiro.

As trincas de retração existentes no local não se devem aos argilominerais existentes no local de estudo, pois estes são pouco ativos. Dessa forma, acredita-se que elas devem ocorrer devido à saturação e secagem do talude, que causam aumento e alívio de tensão no terreno. A largura entre tais trincas que definem a espessura da fatia de escorregamento.

O mecanismo de evolução do processo erosivo estudado se dá da seguinte forma: as chuvas aumentam o teor de umidade do solo podendo, em alguns pontos, atingir a sua saturação. Uma vez saturado, o solo perde sua estrutura e, assim, é facilmente destacado e carreado, provocando a instabilidade dos taludes em fatias. O material escorregado é responsável por uma estabilidade aparente enquanto está depositado no pé do talude. Isso ocorre tanto em condição natural como inundada. Quando o solo depositado é retirado pelo fluxo à jusante, o processo é reativado, como mostrado na representação do mecanismo de instabilização empregando um software de estabilidade de taludes.

Para continuidade deste trabalho sugere-se a realização de um maior número de ensaios Inderbitzen, para possibilitar uma melhor avaliação dos resultados desse tipo de ensaio para o solo local.

Também se recomenda a realização de ensaios de penetração do piezocone (CPTU) para um detalhamento do perfil do subsolo e uma melhor caracterização do solo. 


\section{REFERÊNCIAS BIBLIOGRÁFICAS}

AGENA, S. S.; SAAD, A. M. Estudo da Erodibilidade como Subsídio para o Controle Preventivo da Erosão. In: V Simpósio Nacional de Controle de Erosão. Bauru-SP. 1995. p. 237-239.

ALCÂNTARA, M. A. T.; VILAR, O. M. Aplicação de Métodos de Análise para Avaliação da Erodibilidade de Alguns Solos do Estado de São Paulo. In: VI Simpósio Nacional de Controle de Erosão. Presidente Prudente-SP. 1998. Anais em CD. 14p.

ALMEIDA FILHO, G. S. (2000) Diagnóstico de Processos Erosivos Lineares Associados a Eventos

Pluviosos no Município de Bauru, SP. Dissertação de Mestrado. Campinas. Faculdade de Engenharia Civil. Unicamp. 221 p.

ALMEIDA FILHO, G. S.; RIBEIRO, F. C. Correlação de Processos Erosivos Lineares e Enchentes com Base em Índices Pluviométricos no Município de Bauru-SP. In: V Simpósio Nacional de Controle de Erosão. Bauru-SP. 1995. p. 431-433.

ANTÔNIO, M. A. A Enchente Relâmpago de Bauru de 14 de fevereiro de 1993. IPMET/UNESP.

Bauru. Artigo. Disponível em: http://www.criatividadecoletiva.net/cbm-files/20-

01d53362015d661d77aa3618849ffeee.doc. Acesso em 6 de dezembro de 2007. 5p. ASSOCIAÇÃO BRASILEIRA DE NORMAS TÉCNICAS (1984). Solo - Grãos de solo que passam na

peneira 4,8mm - Determinação da Massa Específica dos Sólidos. Método de Ensaio. NBR 6508/84. ABNT. 8p.

ASSOCIAÇÃO BRASILEIRA DE NORMAS TÉCNICAS (1984). Solos - Análise Granulométrica. Método de Ensaio. NBR 7181/84. ABNT. 13p.

ASSOCIAÇÃO BRASILEIRA DE NORMAS TÉCNICAS (1984). Solo - Determinação do limite de Liquidez. Método de Ensaio. NBR 6459/84. ABNT. 6P.

ASSOCIAÇÃO BRASILEIRA DE NORMAS TÉCNICAS (1984). Solo - Determinação do limite de Plasticidade. Método de Ensaio. NBR 7180/84. ABNT. 3p.

ASSOCIAÇÃO BRASILEIRA DE NORMAS TÉCNICAS (1986). Amostras de solo - Preparação para

ensaios de compactação e ensaios de caracterização. NBR 6457/86. ABNT. 9p.

ASSOCIAÇÃO BRASILEIRA DE NORMAS TÉCNICAS (1990). Solo - Ensaio de Adensamento Unidimensional Método de Ensaio. NBR 12007/90. ABNT. 13p.

ASSOCIAÇÃO BRASILEIRA DE NORMAS TÉCNICAS (2001). Execução de Sondagem de Simples

Reconhecimento nos Solos. ABNT. NBR 6484/01. 17p.

BASTOS, C. A. B. (1999) Estudo Geotécnico sobre a Erodibilidade de Solos Residuais Não Saturados. Tese de Doutorado. Departamento de Engenharia Civil. Porto Alegre. Universidade Federal do Rio Grande do SUl. UFRGS. 251 p. 
CAMARGO, O. A; MONIZ, A. C.; JORGE, J. A.; VALADARES, J. M. A. S. Métodos de Análise Química, Mineralógica e Física de Solos do Instituto Agronômico de Campinas. Instituto Agronômico. Boletim Técnico n 106. Campinas. 1986. p.3-4.

CANIL, K; IWASA, O. Y.; SILVA, W. S.; ALMEIDA, L. E. G. Mapa de Feições Erosivas Lineares do Estado de São Paulo: uma Análise Qualitativa e Quantitativa. In: V Simpósio Nacional de Controle de Erosão.ABGE. Bauru-SP. 1995. v.5, p.249-251.

CAMAPUM DE CARVALHO, J. Mecanismos de Instabilização de Taludes de Erosões. In: IV Conferência Brasileira sobre Estabilidade de Encostas. Salvador-BA. 2005. p.361-371.

CAMAPUM DE CARVALHO, J.; SALES, M. M.; SOUZA, N. M.; MELO, M. T. S. Processos Erosivos no Centro-Oeste Brasileiro. Brasília. 2006. Editora FINATEC. 464 p.

CAVAGUTI, N. (1994). Erosões Lineares e Solos Urbanos: Estudos, Caracterização e Análise da Degradação do Meio Físico em Bauru, SP. Tese de Livre-Docência. Departamento de Engenharia Civil. Bauru. Faculdade de Engenharia e Tecnologia. UNESP/Bauru. 2v.

CAVAGUTI, N. Análise Global da Erosão Linear na Área Urbana de Bauru-SP. In: $\vee$ Simpósio Nacional de Controle de Erosão. Bauru, 1995. p. 301-304.

CAVAGUTI, N.; HAMADA, J. Disposição dos resíduos Sólidos em Erosões e Impactos SanitárioAmbientais em Bauru-SP. artigo. Disponível em: http://www.bvsde.paho.org/bvsaidis/resisoli/mexico/03059p04.pdf. Acesso em 6 de dezembro de 2007. 5p.

CHANDLER, R. J.; HARWOOD, A. H.; SKINNER, P. J. Sample Disturbance in London Clay. Géotechnique 42. №. 4. 1992. p. 577-585.

CINTRA, J. C. A. Aplicações da Mecânica dos Solos Não-Saturados - Fundações em Solos Colapsíveis. In: V Simpósio Brasileiro de Solos Não Saturados. São Carlos, 2004. v. 2 p. 575593

CORGHI, F. N. (2005) Estudos das Limitações do Meio Físico Visando a Apresentação de Diretrizes para a Elaboração de Projetos de Loteamentos no Município de Bauru. Relatório de Iniciação Científica. CNPq. UNESP/FEB. Bauru. 108p.

CORGHI, F. N; GIACHETI, H. L. Processos Erosivos Causados por Loteamentos em Bauru/SP: os Casos dos Residenciais Jardim Colonial e Chácara Odete. In: IV Conferência Brasileira sobre Estabilidade de Encostas. Salvador-BA. 2005. p.373-385.

DAEE/IPT. Controle de Erosão: Bases Conceituais e Técnicas - Diretrizes para o Planejamento Urbano e Regional - Orientações para o Controle de Boçorocas Urbanas. São Paulo. DAEE/IPT, 1989. $2^{a}$ edição, 1990. 92p.

DE MIO, G. (2005) Condicionantes Geológicos na Interpretação de Ensaios Piezocone para Identificação Estratigráfica na Investigação Geotécnica e Geoambiental. Tese de Doutorado. São Carlos. EESC/USP. 348p. 
FABRI, G. T. P. (1994) Caracterização da Fração Fina de Solos Tropicais Através da Adsorção de Azul de Metileno. Tese de Doutorado. São Carlos. EESC/USP. 101 p.

FÁCIO, J. A. (1991) Proposição de uma Metodologia de Estudo da Erodibilidade dos Solos do Distrito Federal. Dissertação de Mestrado. Departamento de Engenharia Civil. Brasília-DF. Universidade de Brasília.107p.

FENDRICH, R.; OBLADEN, N. L.; AISSE, M. M.; GARCIAS, C. M. Drenagem e Controle da Erosão Urbana. Editora Universitária Champagnat. Curitiba. $4^{a}$ edição. 1997. 485p.

FERREIRA, A. A.; NEGRO JUNIOR, A.; ALBIERO, J. H.; CINTRA, J. C. A. Solos do Interior de São

Paulo. Associação Brasileira de Mecânica dos Solos. Departamento de Geotecnia da Escola de Engenharia de São Carlos - USP. São Paulo, 1993.339p.

FERREIRA, M. D. (2004) Análise da Evolução de Processos Erosivos Acelerados em Áreas Urbanas e das Técnicas de Controle e Recuperação - Córrego do Tucum (São Pedro/SP). Dissertação de Mestrado. Departamento de Geotecnia. São Carlos. EESC/USP. 171 p.

FERREIRA, M. D.; PEJON, O. J. Processos Erosivos Acelerados: Comportamento Temporal e Espacial de Voçoroca. Revista Geotecnia no. 110. 2007. p. 101-119.

FRAGASSI, P. M. F.; MARQUES, E. A. G. Desenvolvimento de uma Nova Versão do Aparelho Inderbitzen. In: VII Simpósio Nacional de Controle de Erosão. Goiânia, 2001. Anais em CD. $8 p$.

FREIRE, E. P. Ensaio Inderbitzen Modificado: um Novo Modelo para Avaliação do Grau de Erodibilidade do Solo. In: VII Simpósio Nacional de Controle da Erosão. Goiânia, 2001. Anais em CD.

FUTAI, M. M. (2002) Estudo Teórico-Experimental do Comportamento de Solos Tropicais NãoSaturados: Aplicação a um Caso de Voçorocamento. Tese de Doutorado. Rio de Janeiro. COPPE/UFRJ. 559 p.

FUTAI, M. M.; ALMEIDA, M. S. S. e LACERDA, W. A. Evolução de uma Voçoroca por Escorregamentos Retrogressivos em Solo Não-saturado. In: IV Conferência Brasileira sobre Estabilidade de Encostas. Salvador, 2005. Vol. 1 p. 443-452.

GUERRA, A. J. T.; SILVA, A. S.; BOTELHO, R. G. M. Erosão e Conservação dos Solos: Conceitos, Temas e Aplicações. $3^{a}$ edição. Rio de Janeiro. 2007. Ed. Bertrand Brasil. 339p.

HEAD, K. Manual of Soil Laboratory Testing. Volume 2. Pentech Press. London: Plymouth. 1982.

IDE, D. M. (2006) Estudos das Limitações do Meio Físico Visando a Apresentação de Diretrizes para a Elaboração de Projetos de Loteamentos no Município de Bauru. Relatório de Iniciação Científica. CNPq. UNESP/FEB. Bauru. 35p.

INDERBITZEN, A. L. An Erosion Test for Soils. Materials Research \& Standards. Philadelphia, v.1, n.7. 1961. p.553-554. 
INFANTI JUNIOR, N.; FORNASARI FILHO, N. Geologia da Engenharia.Capítulo 9. Processos de

Dinâmica Superficial. Associação Brasileira de Geologia de Engenharia. São Paulo, 1998. INSTITUTO DE PESQUISAS TECNOLÓGICAS - IPT. Plano de Obras de Contenção das Erosões

Urbanas do Município de Bauru, SP - $2^{\circ}$ fase: Aplicação da Carta Geotécnica. São Paulo, 1994. Relatório n`32207. 301 p.

IWASA, 0. Y.; FENDRICH, R. Geologia de Engenharia. Capítulo 16 - Controle da Erosão Urbana. Associação Brasileira de Geologia de Engenharia. São Paulo, 1998.

JORGE, F. N.; UEHARA, K. Geologia de Engenharia. Capítulo 7 - Águas de superfície. Associação Brasileira de Geologia de Engenharia. São Paulo, 1998.

LAFAYETTE, K. P. V.; COUTINHO R. Q.; QUEIROZ, J. R. S. Avaliação da Erodibilidade como Parâmetro no Estudo de Sulcos e Ravinas numa Encosta no Cabo de Santo Agostinho-PE. In: IV Conferência Brasileira sobre Estabilidade de Encostas. Salvador, 2005. p. 387-399.

LIBARDI, P. L. Dinâmica da Água no Solo. Departamento de Física e Meteorologia. ESALQ/USP. Piracicaba, 1995. 497p.

LIMA, M. C.; CAMAPUM DE CARVALHO, J.; PEREIRA, H. F. Caracterização Geotécnica de

Perfis de Solo da Voçoroca Ceilândia - Distrito Federal. In: VII Simpósio Nacional de Controle de Erosão. Goiânia, 2001. Anais em CD.

MARINHO, F. A. M. (1995) A Técnica do Papel Filtro para Medida de Sucção. In: Encontro sobre Solos Não Saturados. Rio Grande do Sul. 14p.

MENDES, C. A. R. (2006) Erosão Superficial em Encosta Íngreme sob Cultivo Perene e com

Pousio no Município de Bom Jardim - RJ. Tese de Doutorado. Departamento de Engenharia Civil. Rio de Janeiro. COPPE/UFRJ. 227p.

MOREIRA, C. V. R.; PIRES NETO, A. G. Geologia de Engenharia. Capítulo 5 - Clima e Relevo. Associação Brasileira de Geologia de Engenharia. São Paulo, 1998.

MORTARI , D. (1994) Caracterização Geotécnica e Análise do Processo Evolutivo das Erosões no Distrito Federal. Dissertação de Mestrado. Departamento de Engenharia Civil. Brasília. Universidade de Brasília. 200p.

NOGAMI, J. S.; VILLIBOR, D. F. Soil Characterization of Mapping Units for Highway Purposes in a Tropical Area. Bulletin of the International Association of Engineering Geology. n 19. 1979. p. 196-199.

NOGAMI, J. S.; VILLIBOR, D. F. Pavimentação de Baixo Custo com Solos Lateríticos. Ed. Vilibor. São Paulo, 1995. 213p.

PEJON, O. J. Mapeamento Geotécnico Regional da Folha de Piracicaba-SP (escala 1:100.000): Estudo de Aspectos Metodológicos, de Caracterização e de Apresentação de Atributos. São Carlos. Tese de Doutorado. Escola de Engenharia de São Carlos, Universidade de São Paulo. 1992. 
POPI, O. Determinação e Análise de Escoamentos Unidimensionais e Bidimensionais Transientes em Meio Porosos Não-Saturados. São Carlos. Dissertação de Mestrado. Departamento de Hidráulica e Saneamento. Escola de Engenharia de São Carlos, Universidade de São Paulo. 1982. 75p.

QUEIROZ, R. C. (1986) Aplicação do Método de Retroanálise no Estudo da Estabilidade de Taludes de Estradas Situadas em Solos Oriundos da Formação Adamantina. Dissertação de Mestrado. Departamento de Geotecnia. São Carlos. EESC/USP. 98p.

RAMIDAN, M. A. S. (2003) Estudo de um Processo de Voçorocamento próximo a UHE de Itumbiara-GO. Dissertação de Mestrado. Departamento de Engenharia Civil. Rio de Janeiro. PUC-Rio. 242 p.

ROBERTSON, P. K.; CAMPANELLA, R. G. Guidelines for Use, Interpretation and Application of the CPT and CPTU. University of British Columbia. Department of Civil Engineering. Vancouver (CA). 1986. Third edition. 197 p.

RODRIGUES, J. E. (1982) Estudo de Fenômenos Erosivos Acelerados - Boçorocas. Tese de Doutorado. Departamento de Vias de Transporte e Topografia. São Carlos. EESC/USP. $162 \mathrm{p}$.

RODRIGUES, R. A. (2007) Modelação das Deformaçōes por Colapso Devidas à Ascensão de Lençol Freático. Tese de Doutorado. Departamento de Geotecnia. São Carlos. EESC/USP. 262p.

SALOMÃO, F. X. T.; QUEIROZ NETO, J. P. Estudo da Erosão em Bauru (SP) Visando o Planejamento de Uso do Solo. In: V Simpósio Nacional de Controle de Erosão. Bauru, 1995. p. 241-244.

SANTOS, P. S. Ciência e Tecnologia de Argilas. Editora Edgard Blücher. 2nd. ed. 3 vol. 1989. $1089 \mathrm{p}$.

SANTOS, C. A.; MERSCHMANN, M. A. C. Ensaio de Erodibilidade como Parâmetros no Estudo de Ravinas e Voçorocas, na Região de Santo Antônio do Leite, Distrito de Ouro Preto-MG. In: VII Simpósio Nacional de Controle de Erosão. Goiânia, 2001. Anais em CD.

STANCATI, G.; NOGUEIRA, J. B.; VILAR, O. M. Ensaios de Laboratório de Mecânica dos Solos. São Carlos. 1981. EESC-USP. 208p.

STEIN, D. P. Diagnóstico de Erosão. In: V Simpósio Nacional de Controle de Erosão. Bauru, 1995. v.5 p. 55-57.

TEIXEIRA, R. S. (1996) Resistência ao Cisalhamento de um Solo Compactado Não Saturado. Dissertação de Mestrado. Departamento de Geotecnia. São Carlos. EESC/USP. 161 p.

VAN GENUTCHEN, M. T. A Closed-form Equation for Predicting the Hydraulic Conductivity of Unsaturated Soils. Soil Science Society of America Journal. 1980. v.44 (5), p. 892-898.

VILAR, O. M. (1987) Formulação de Modelo Matemático para a Erosão dos Solos pela Chuva. Tese de Doutorado. Departamento de Geotecnia. São Carlos. EESC/USP. 196p. 
VILAR, O. M.; CINTRA, P. C. A.; PARAGUASSU, Q. B.; MACHADO, R. L.; CARVALHO, S. F.; CARNEIRO, B. I. J. Ensaios de Campo e de Laboratório em Solos Não-saturados. In: Encontro Sobre Solos Não-Saturados. Porto Alegre (RS), 1995. UFRGS. p.184-201. 


\section{APÊNDICE A.1 - Inderbitzen da amostra 1}

\section{Escoamento laminar $\left(15^{\circ}, 31^{\circ}\right.$ e $\left.50^{\circ}\right)$}
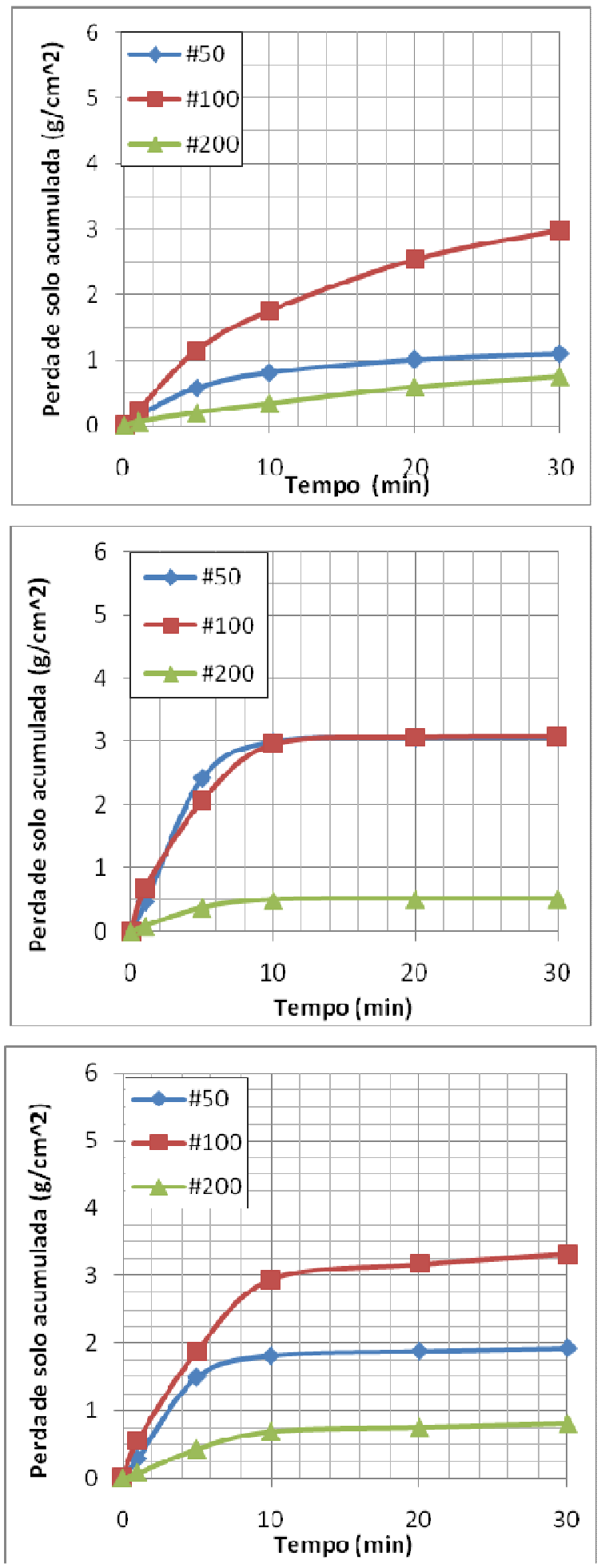
Ação da gota $\left(15^{\circ}, 31^{\circ}\right.$ e $\left.50^{\circ}\right)$
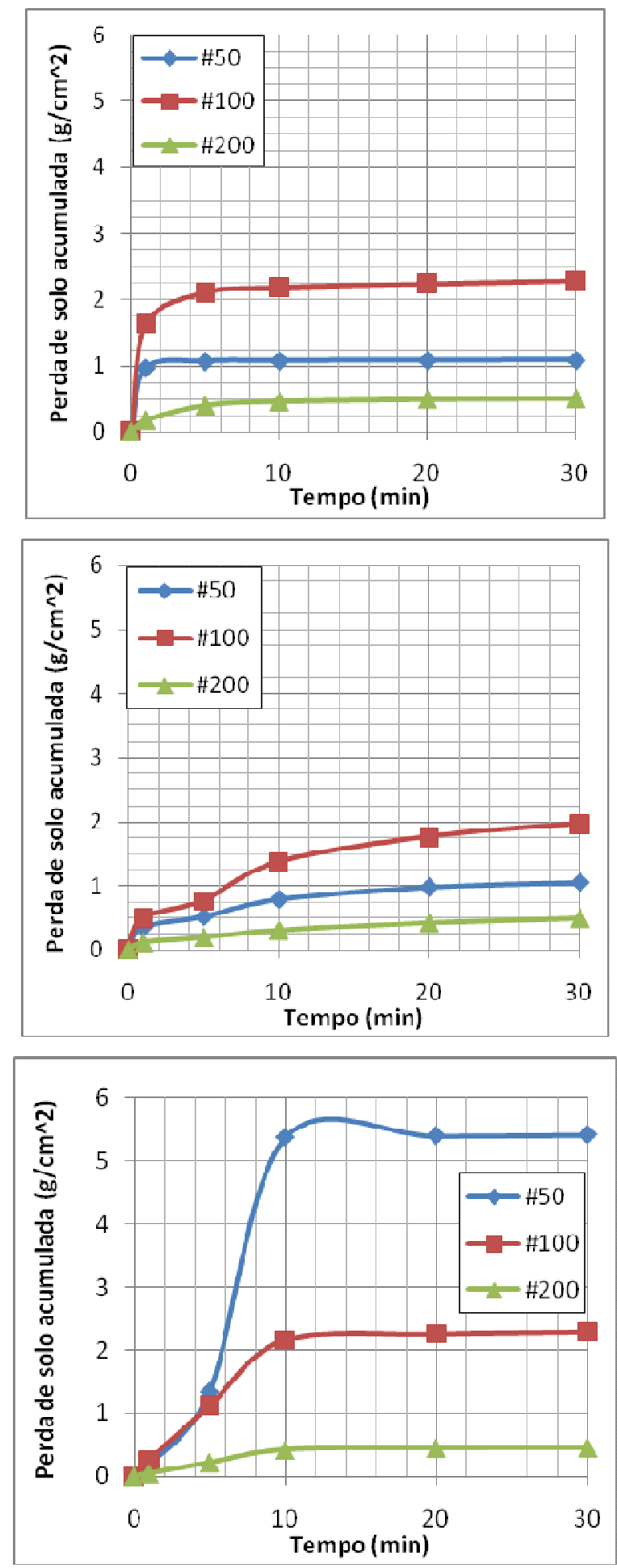


\section{APÊNDICE A.2 - Inderbitzen da amostra 2}

\section{Escoamento laminar $\left(15^{\circ}, 31^{\circ}\right.$ e $\left.50^{\circ}\right)$}
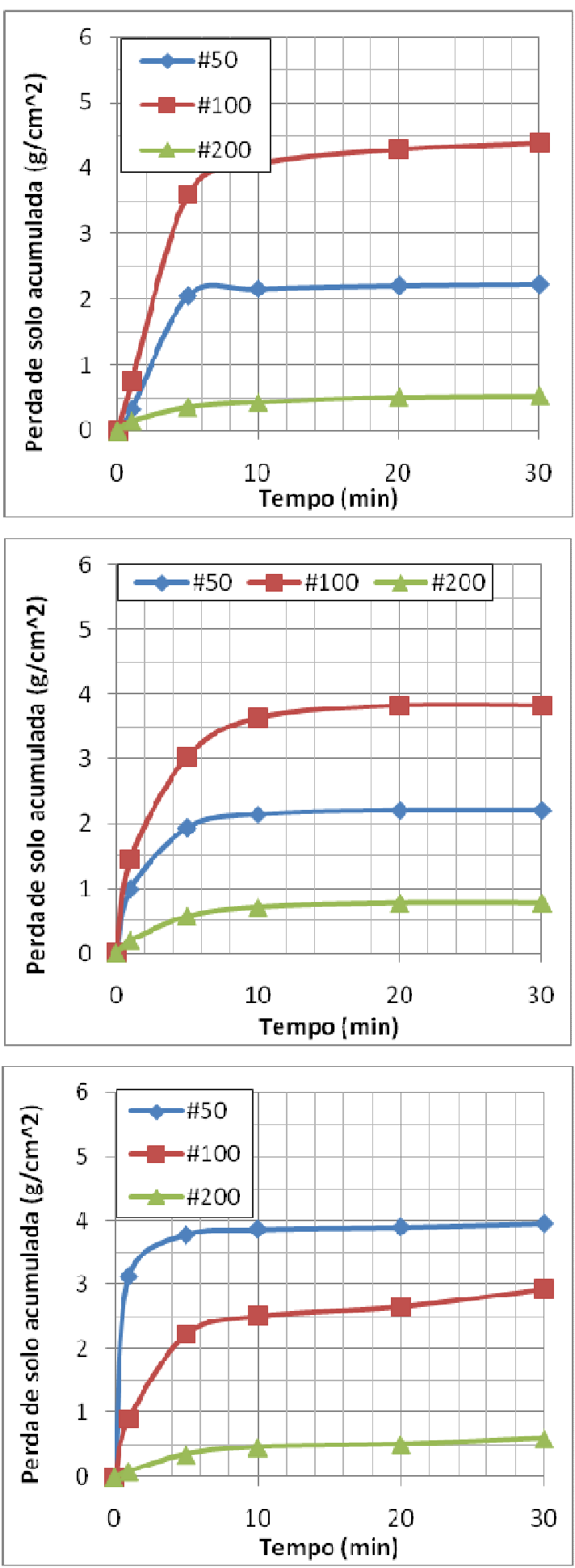
Ação da gota $\left(15^{\circ}, 31^{\circ}\right.$ e $\left.50^{\circ}\right)$
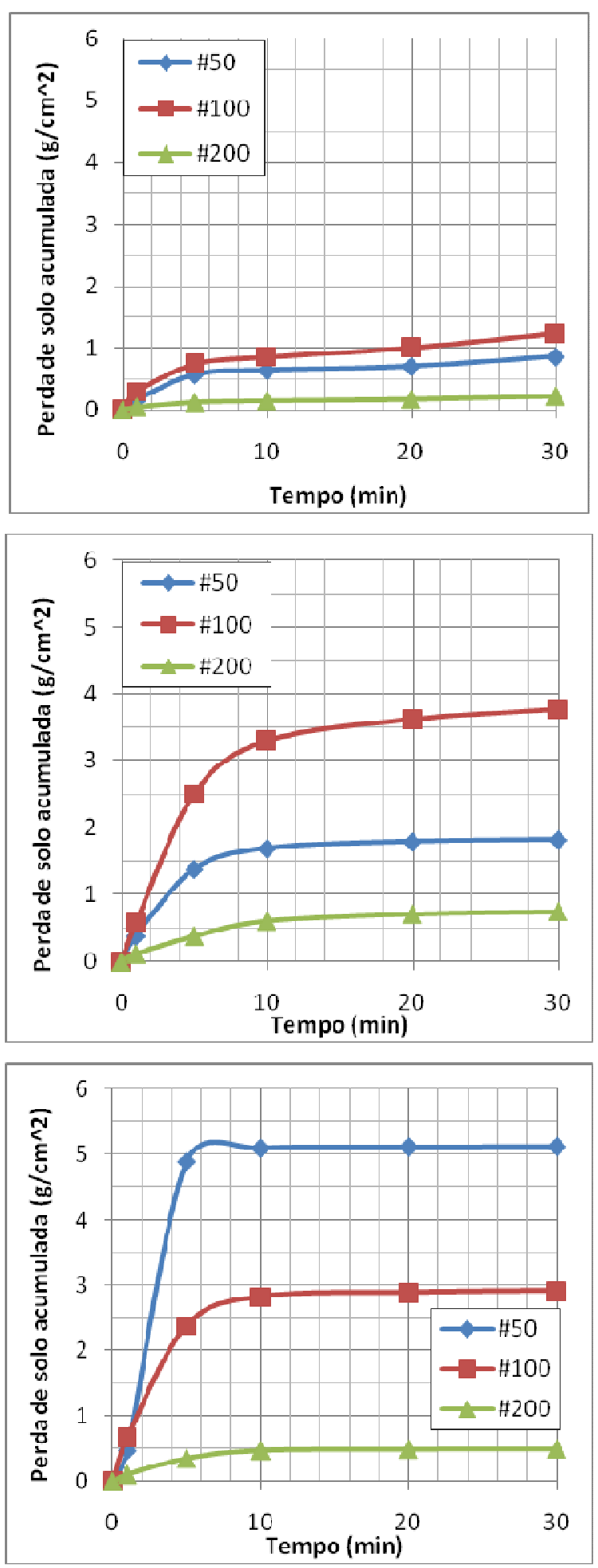


\section{APÊNDICE A.3 - Inderbitzen da amostra 3}

\section{Escoamento laminar $\left(15^{\circ}, 31^{\circ}\right.$ e $\left.50^{\circ}\right)$}
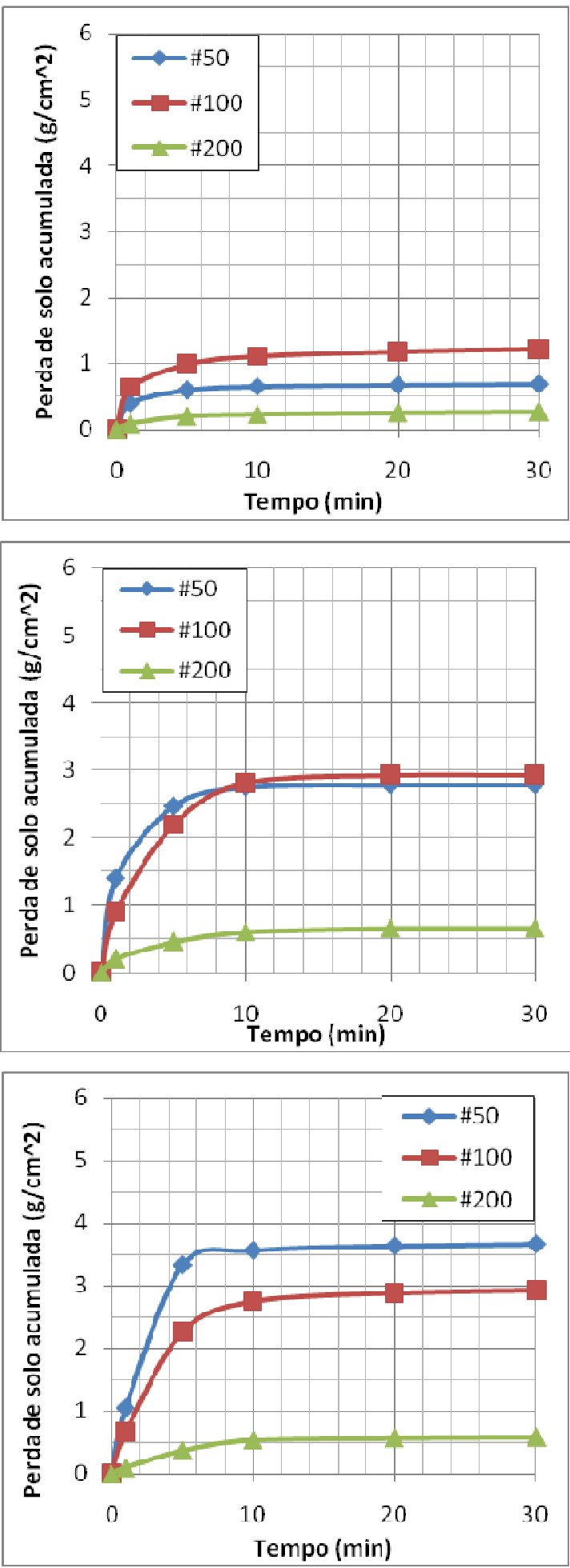
Ação da gota $\left(15^{\circ}, 31^{\circ}\right.$ e $\left.50^{\circ}\right)$
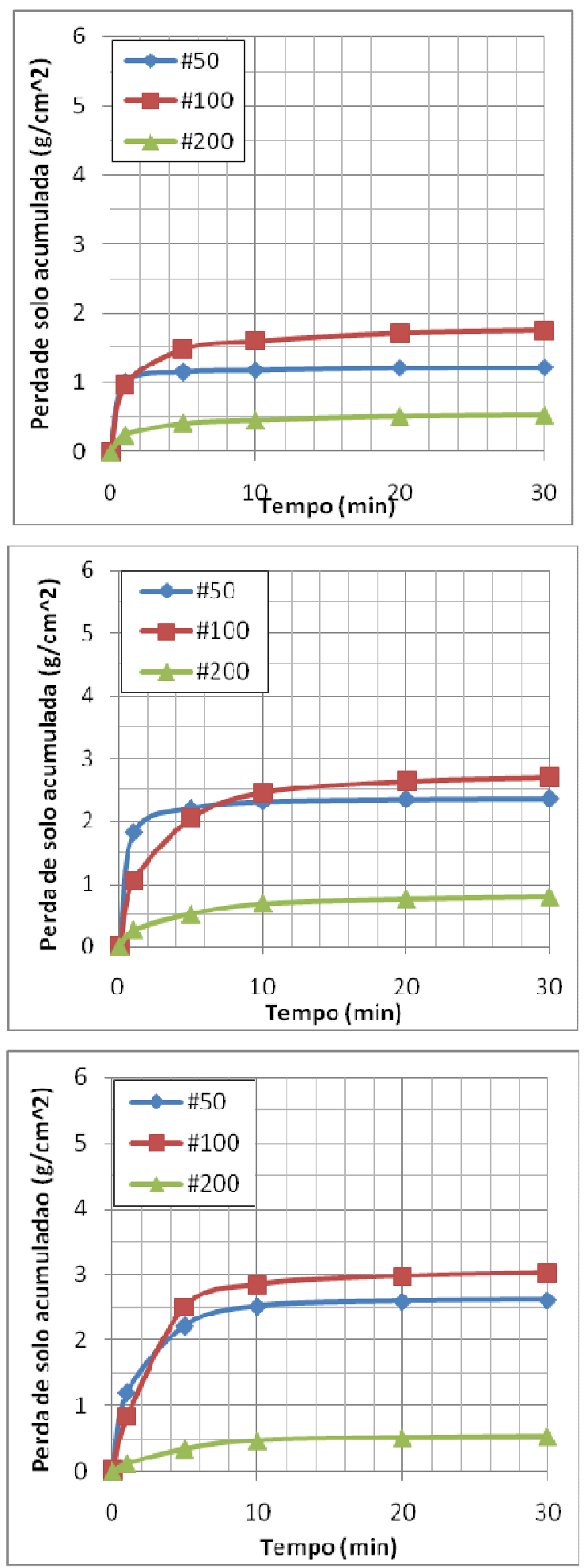